\title{
أخلاقيات التواصل الإنساني والإنمائي في تجليّيات الحضارة الإسلامية الغالبة
}

* ناصر يوسف

*** محمد بلغيث

ليس في إمكان أي حضارة غالبة أن تحافظ على وتيرةا، إنْ لم تحافظ في الوقـــت نفسه على الإرث الإنساني والإنمائي للحضارات المغلوبة. فكلما كانت الحضاريه المارة الغالبة

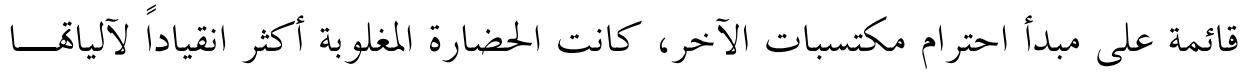

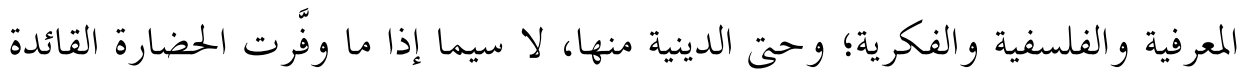

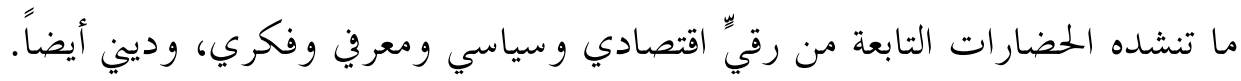

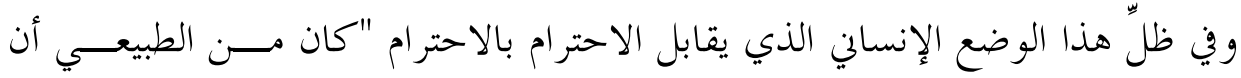

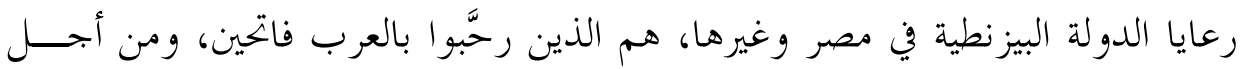

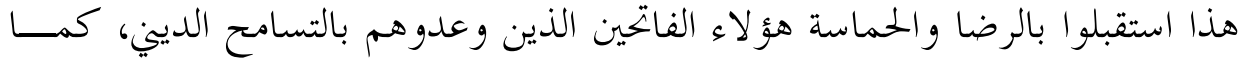

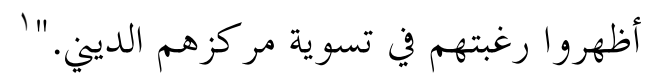

إن تطوُّر الحضارة المنفتحة على مكتسبات الآخر المغلوب، يواكبها تطوُّر فكري،

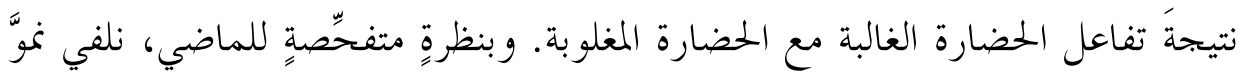

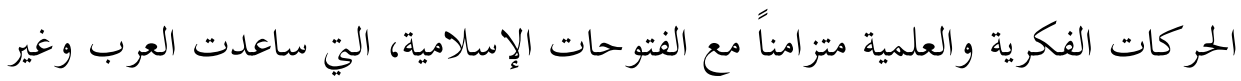

دكتوراه في اقتصاد التنمية المقارن- باحث جزائري- مركز البحوث- الجامعة الإسلامية العالمية- ماليزيا. البريد

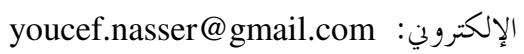

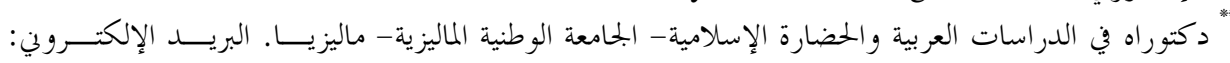
silman54@yahoo.com ' أحمد، نريمان عبد الكريم. معاملة غير المسلمين في الدولة الإسلامية، القاهرة: الهيئة المصرية العامــة للكتـــاب، 


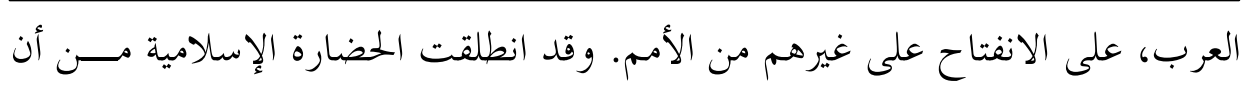

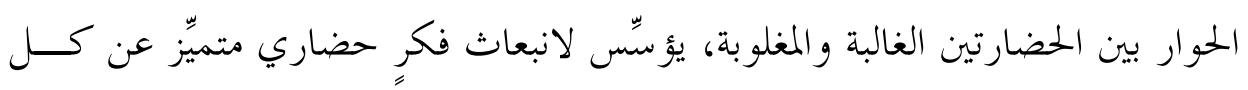

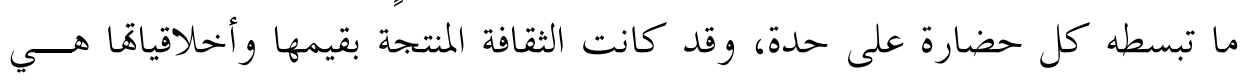
المقياس الذي يقيس نوعية الحضارات، كما ظلَّت النظرة الإنسانية لإنسان أهمَّ ما يميِّ

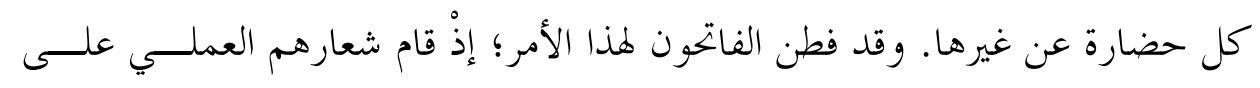

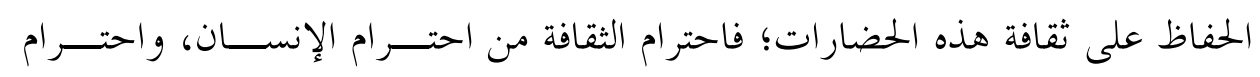

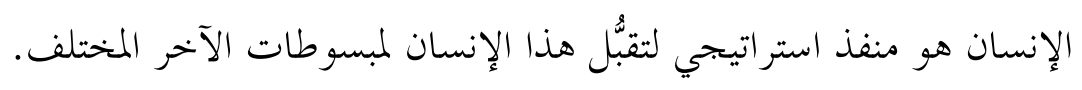
لقد شكَّل هذا التواصل الإنساني والإنمائي بين الحضارت، أهمَّ أســــرار حفـــاظ

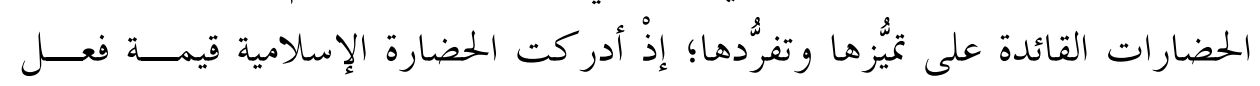

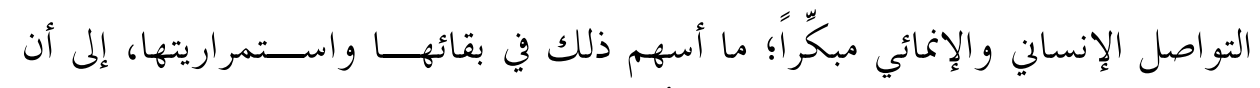

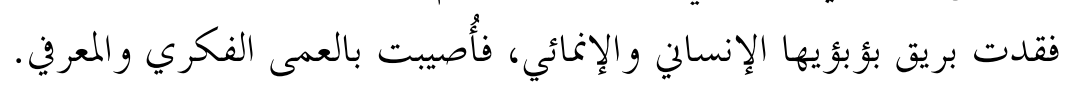

\section{أولاً: حول مفهوم التواصل الإنساين والإنمائي}

لقد تعلَّدت المفاهيم حول التواصل، وتباينت بتباين إيديولوجيات أصــحاهـا، لا سيما أن من اشتغلو اعلى مصطلح التواصل، يعيشون في كنف الحضارة الغربية الغالبة، و يقلقهم الثقب الأسود الآخذ بالاتساع في حضارقم. فهم يعكفون على إيجاد حلول فلسفية للآلة العلمية، التي أفرزت هذا التطور التكنولوجي، ويكاد يكون -في نظرهم-

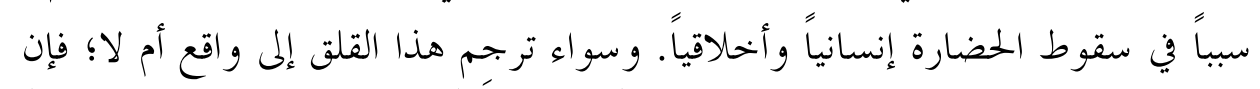

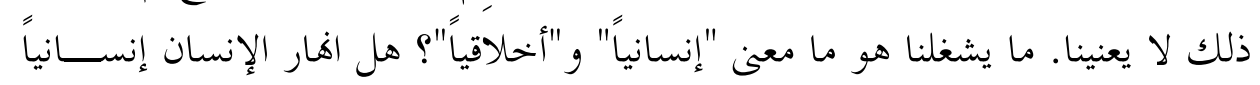

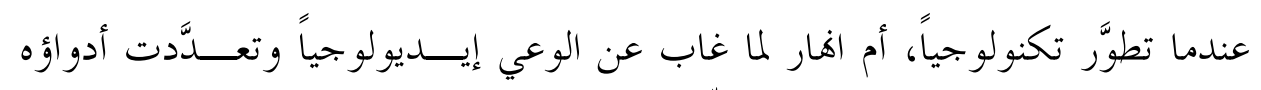

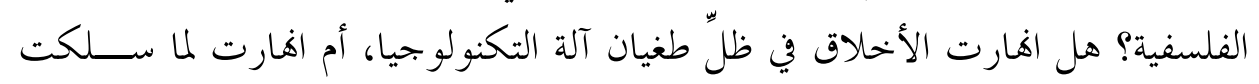
هذه الحضارة مسلكاً لا إنسانياً الان

لا شكَّ في أن الإنسان ينهار في اللحظة التي يخالف فيها فطرته، وتتميَّع الأخـــلاق

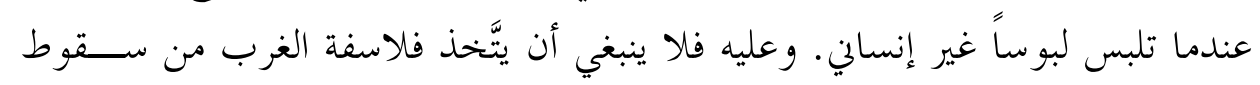




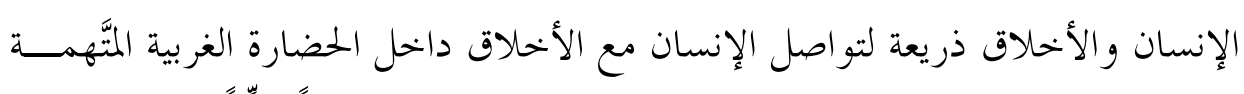

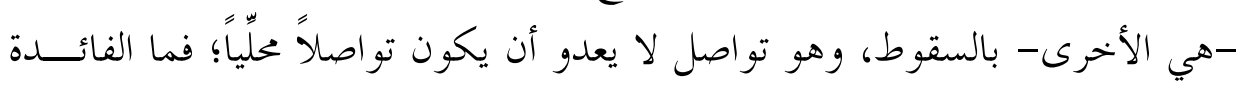

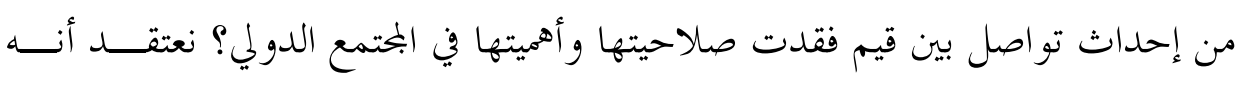
على فلاسفة التواصل إعادة النظر في منظومة التواصل الإيديولوجية، التي تضيق بضيق

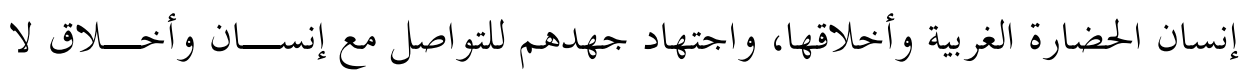

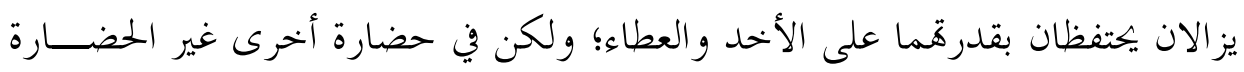
الحالية، أو الاستفادة من الحضارات البشرية الأخرى، التي اكتسب فيها التواصل أهمية

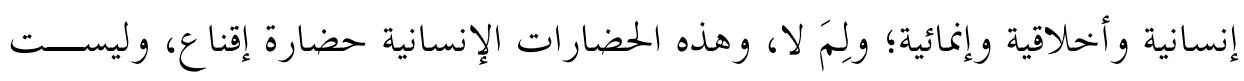
حضارة قناع؟

عموماً، مفهوم التواصل مفهوم فضفاض، أفرزته الرؤية الإيديولوجية للحضــارة،

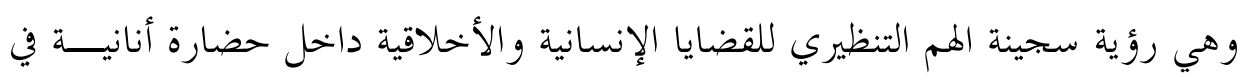
إنسانيتها ومتميِّة في أخلاقها؛ بينما تغاضت هذئة هذه الرؤية عن القيم التطبيقية الفاعلة في

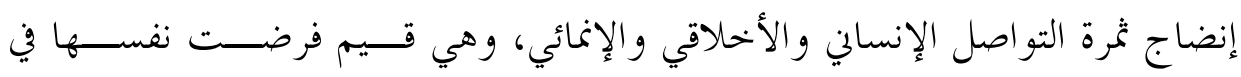

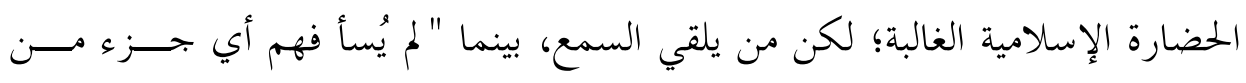

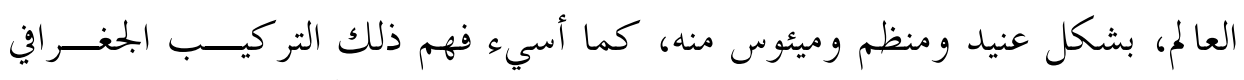

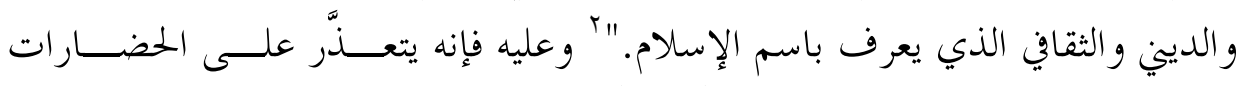

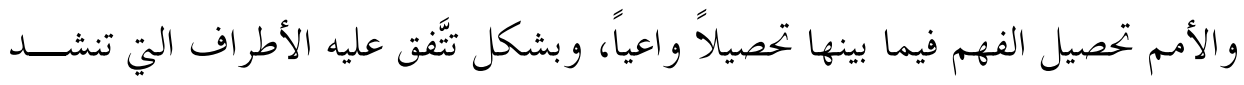

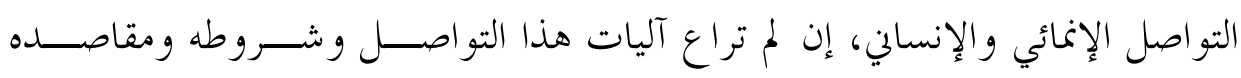
وأخحلاقاته.

\section{ا ـ آليات التو اصل الإنساني والإنمائي:}

في ظلِّ التواصل تتداخل الثقافات و المستويات، و تتعايش فيما بينها؛ فلا و وجــــود

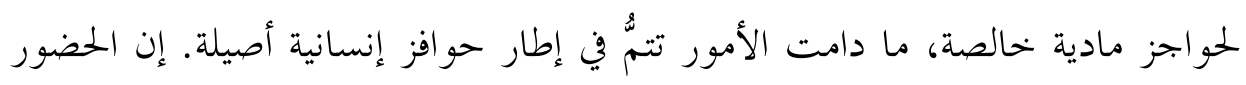

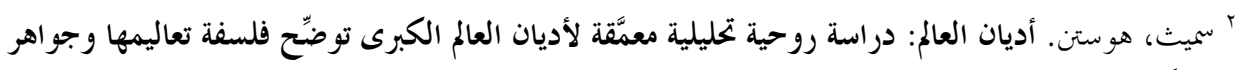

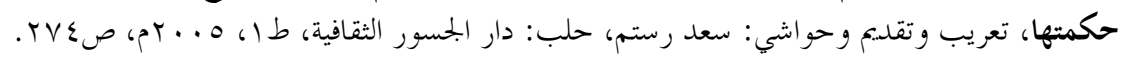




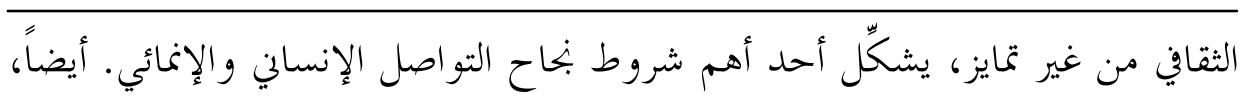

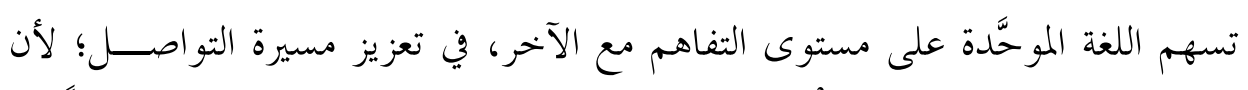

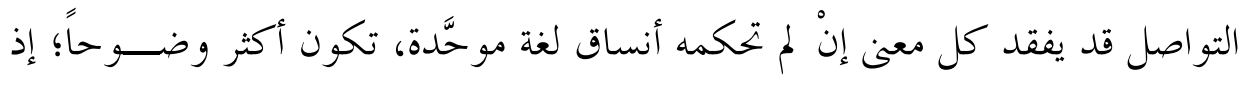

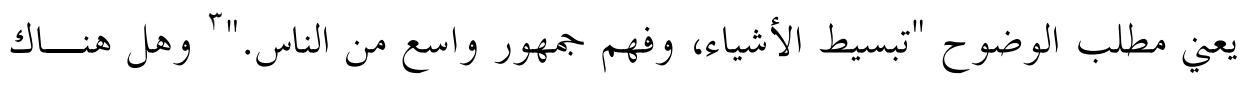

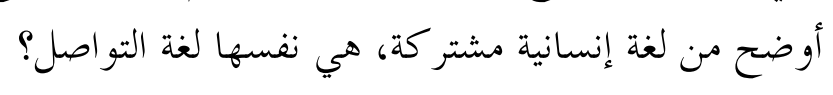

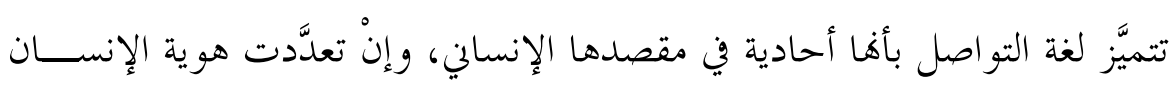

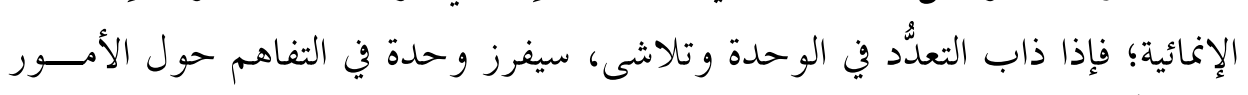

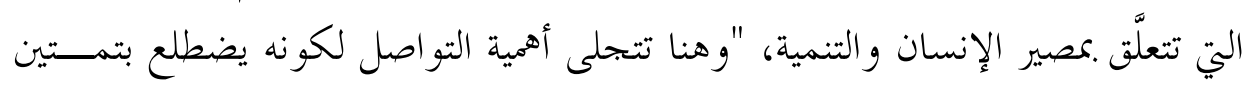

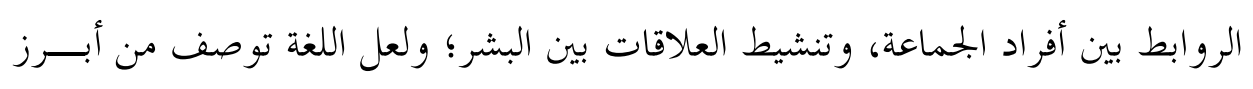

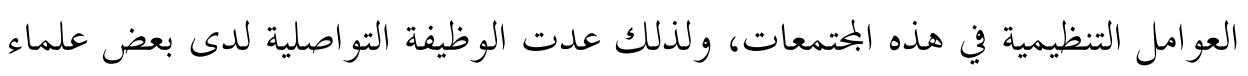

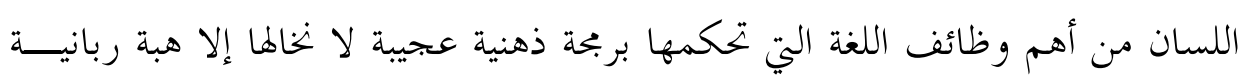

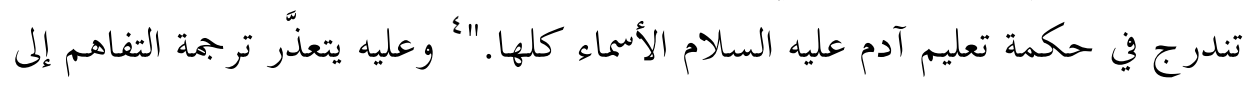

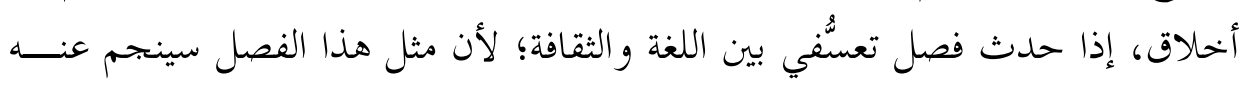

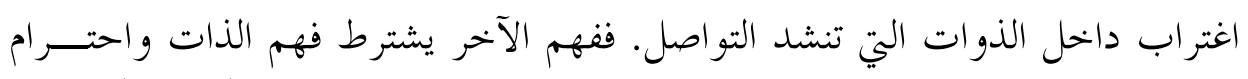

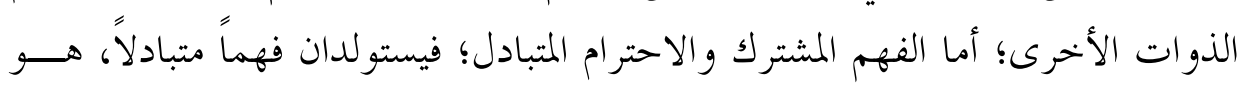

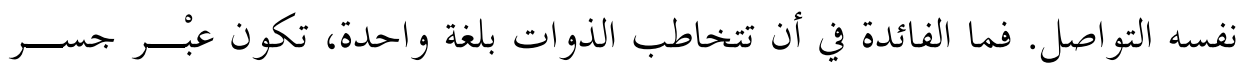

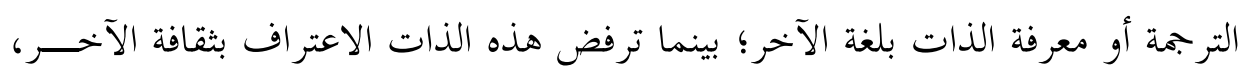

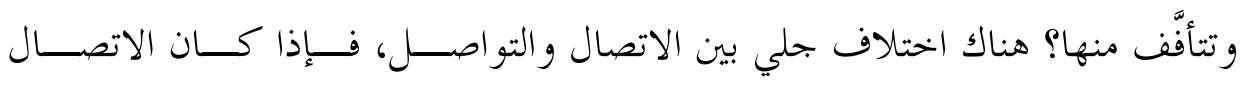

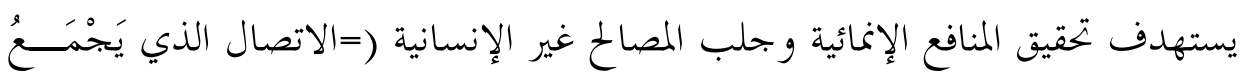

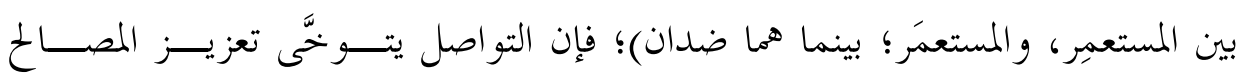

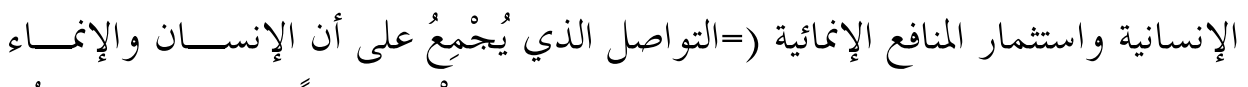

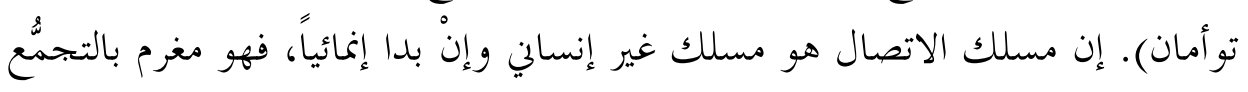

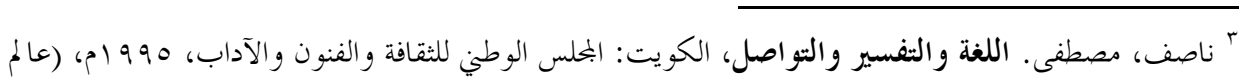

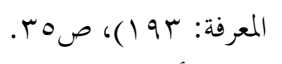
" يوسف، أمدا. سيميائيات التواصل وفعالية الحوار: المفاهيم والآليات، وهر ان: منشورات ختتبر السـيميائيات

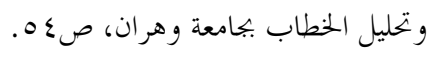




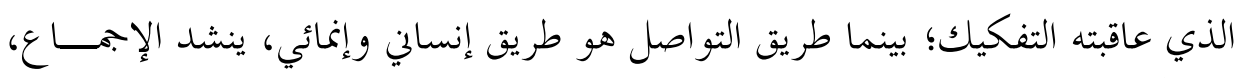
وغالباً ما تكون غايته الفكيك؛ بينما طريت

إن القاسم المشترك بين الاتصال والتواصل هو التنمية وليس الإنســان. فكلمـا

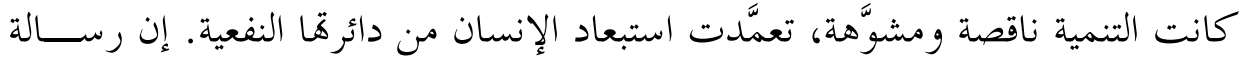

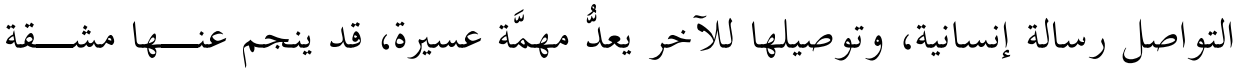

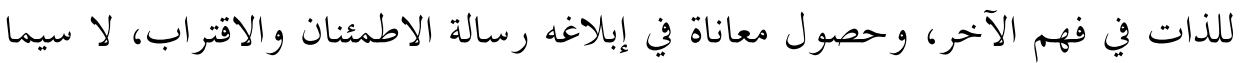

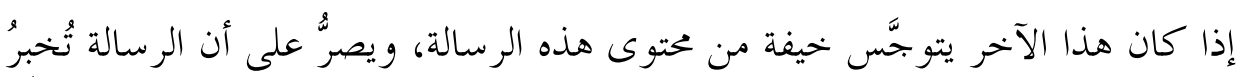

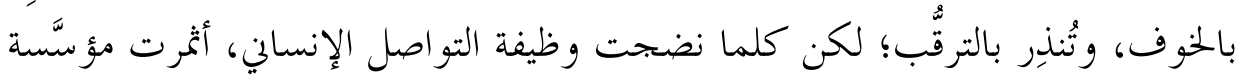

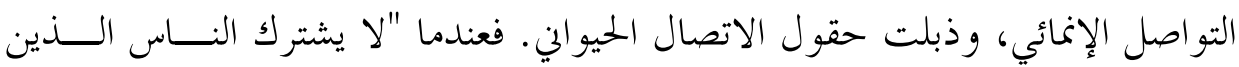

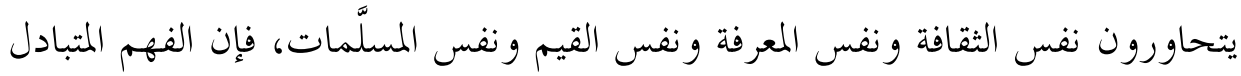

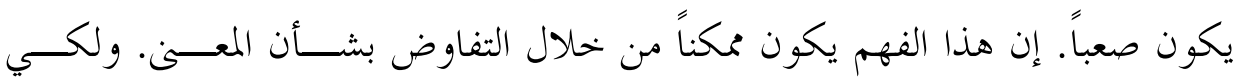

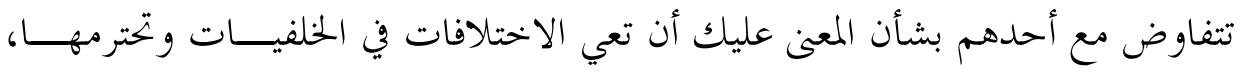

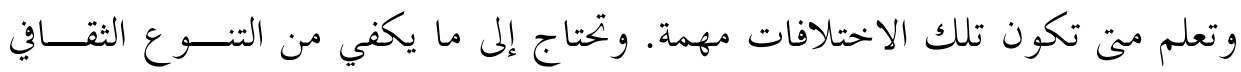

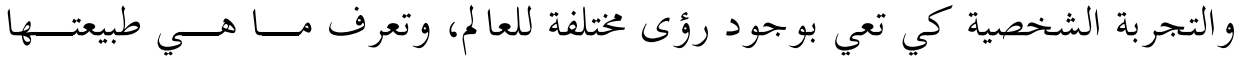

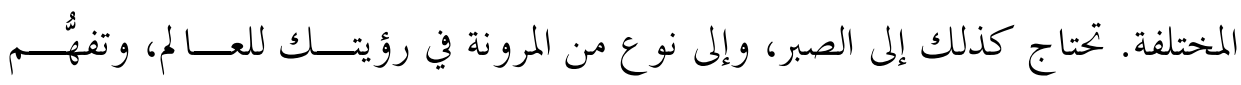

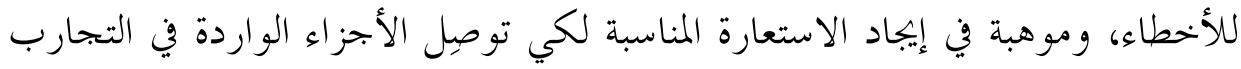

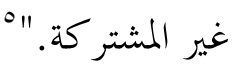

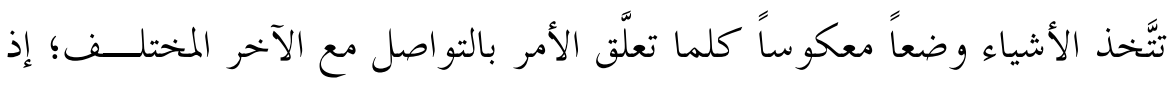

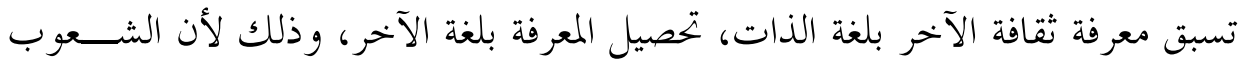

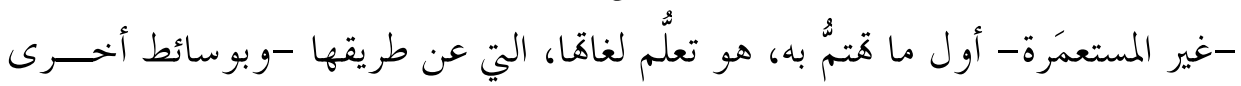

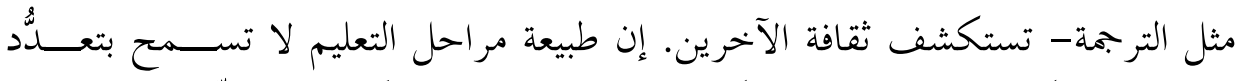

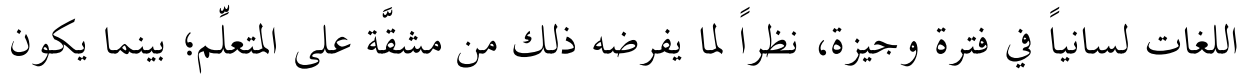

• لايكوف، جورج وجونسون، مارك. الاستعارات التي نحيا هلا، ترجمة: عبد الجيد جحفة، الـــار البيضــاء: دار

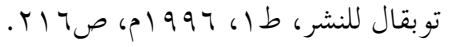




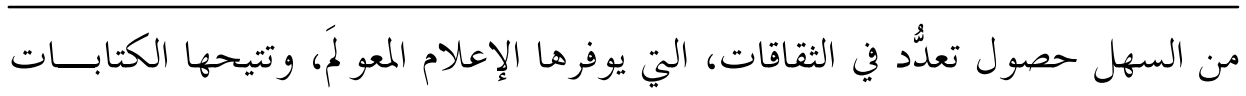
المتر جمة.

تأسيساً على ما سبق، فإن التو اصل الإنساني و الإنمائي يخضع لآليتين هما:

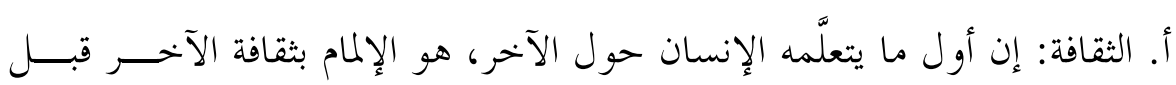

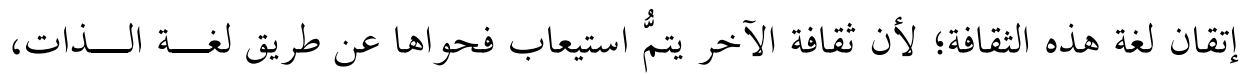

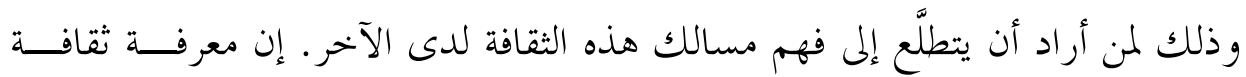

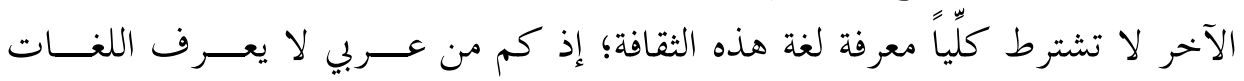
الأوربية، ولكن على إلمام متو اضع بثقافة هذه اللغات. إن التواصل الثقافي أمر ممكن في التهن

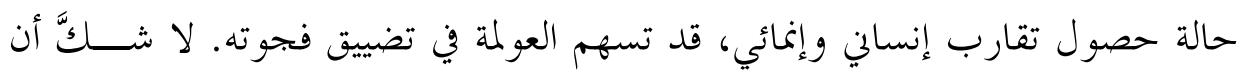

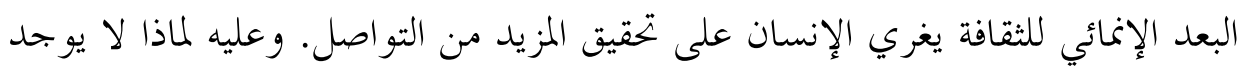

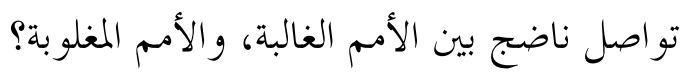

يظهر حاجز التواصل نتيجة الفراغ الإنمائي، الذي يجمع بين ثقافات هذه الأمـــــ

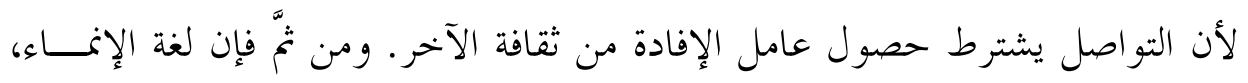

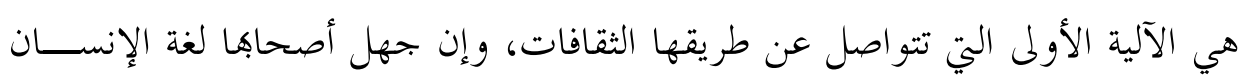

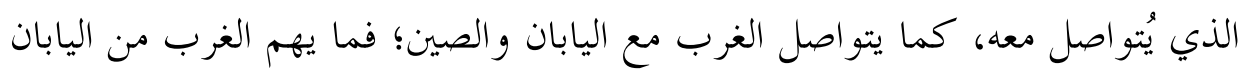
و الصين، هو الجانب الإنمائي وليس الإنساني. وبناء على ذلك فإنه إلى جانب المبت المصلحة

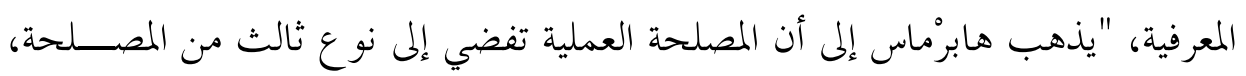

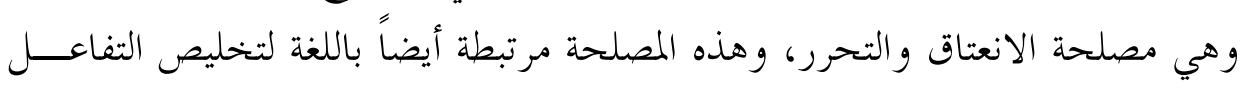

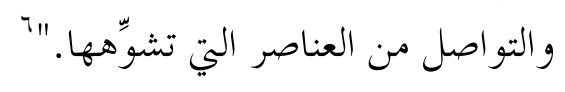

ب. اللغة: لا شكَّ أن معرفة لغة الآخر، تشكِّل أفضل آليــة لتنميـــة التواصــل

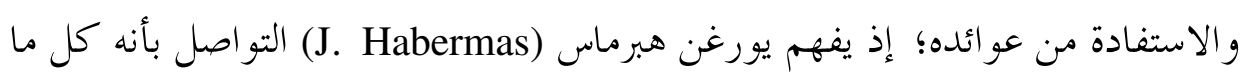

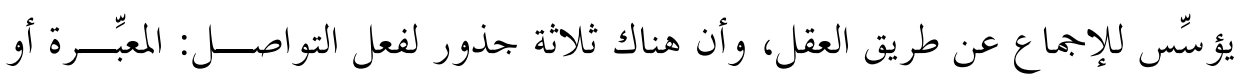

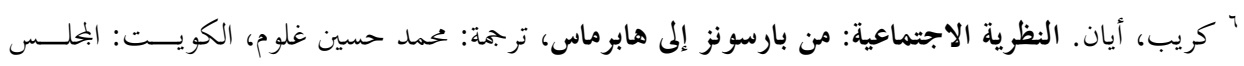

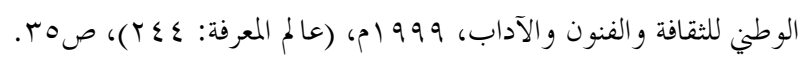


التعبير القصدي والوصفي؛ إقامة علاقة بين الذات والآخر؛ ثم المقترحة. ` فقعل التواصل

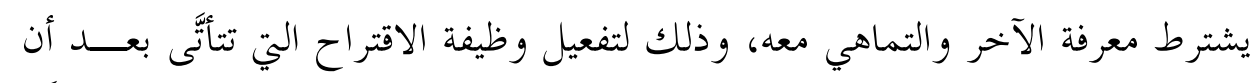

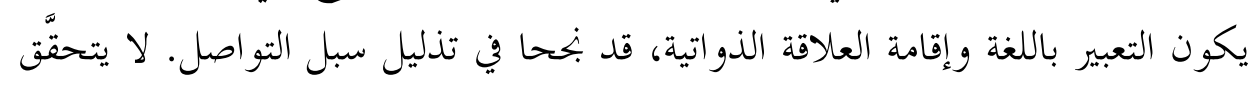

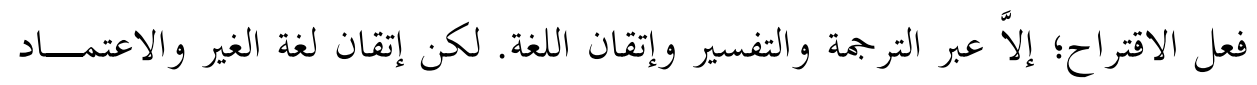

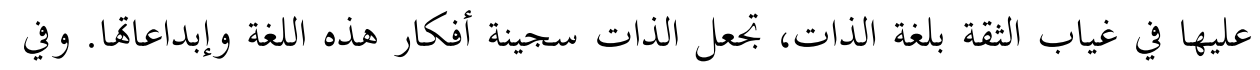

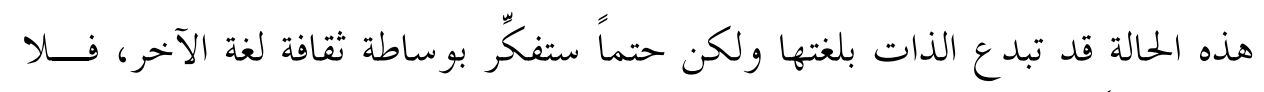

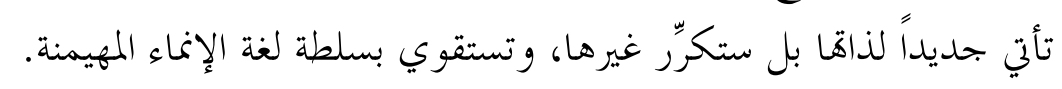

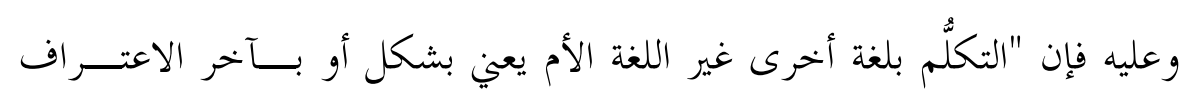
بسلطة ومنطق ومقاصد نظام القوي الذي تكون هذه اللغة أداته. فاللغة الأمريكية هي لغة الأعمال و التقنية. إها، شأن كل اللغات، مفهوم للعالم، و نظام دقيق يقتضي طاعته

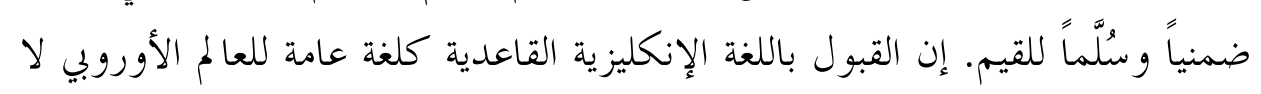
يعني فقط اختيار سهولة أدواتية ووسيلة غير أساسية وملائمة للاتصال، بل يعين سيامة

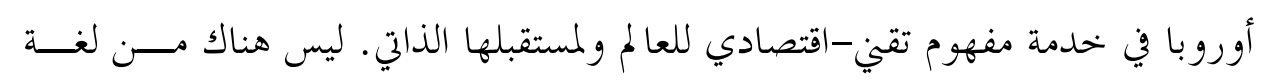

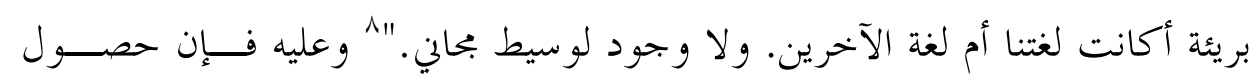

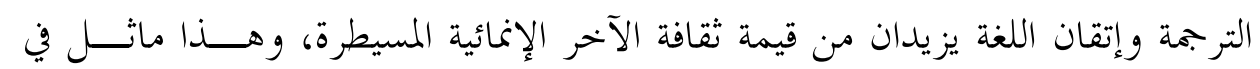
الغرب الذي يجتهد لإتقان اللغتين اليابانية والصينية.

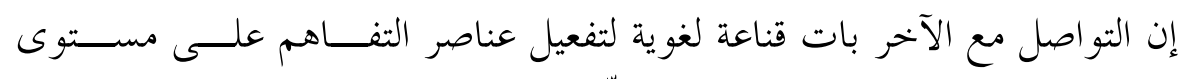

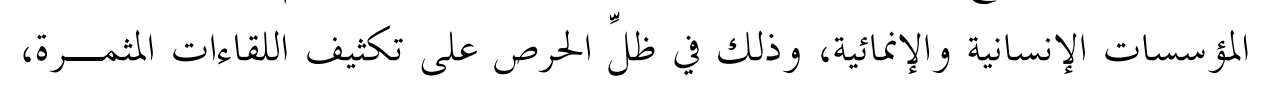

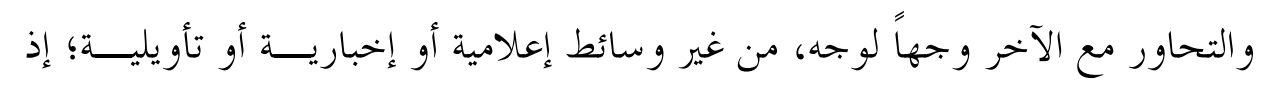

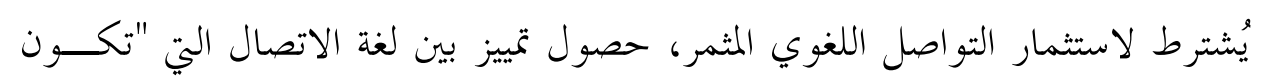

${ }^{7}$ Habermas, Jurgen. The Theory of Communicative Action: Lifeworld and System: A Critique of Functionalist Reason, Translated by Thomas McCarthy, Boston: Beacon Press, 1987, Volume 2, p 62.

^ دوبريه، ريجيس. محاضرات في علم الإعلام العام: الميديولو جيا، ترجمة: فؤاد شاهين وجور رجيت الحسَّاد، بيروت:

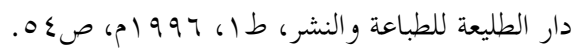




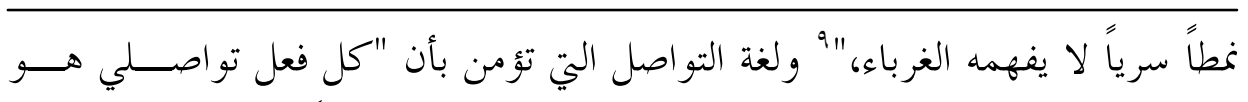

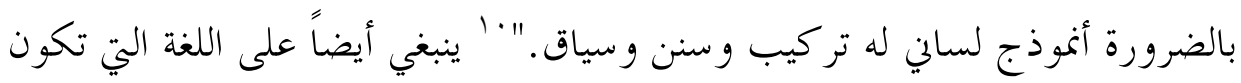

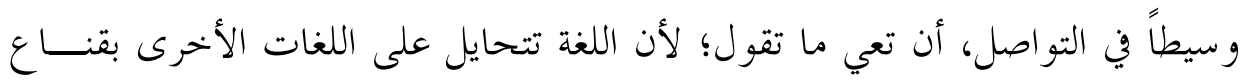

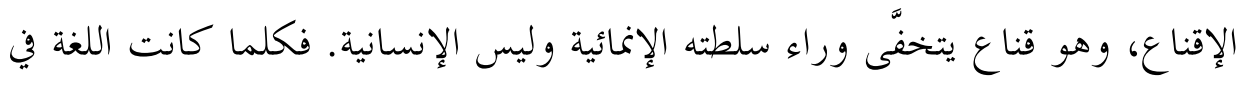

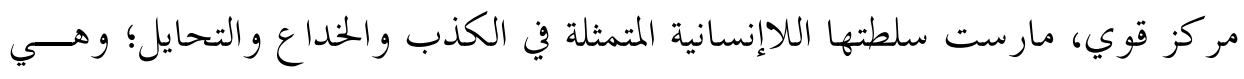

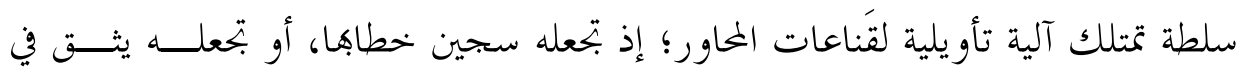

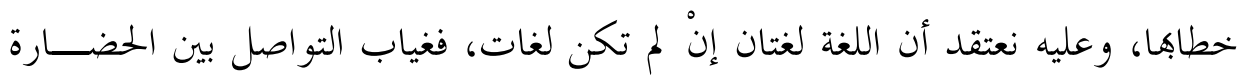

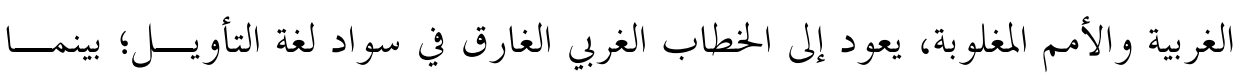

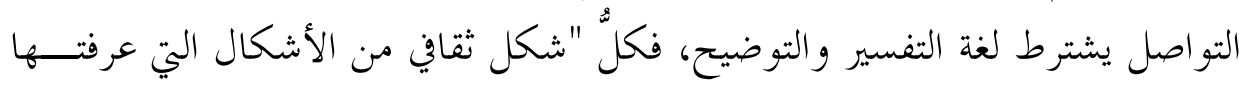

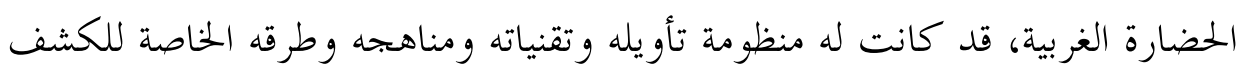

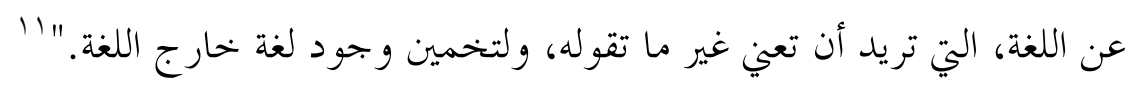

\section{Y ب . شروط التواصل الإنسالي والإنغائي:}

هناك شروط يُفترَض أن تتوفر بين من ينشدون تمديد حبل التواصل بينهم وتمتينه؛

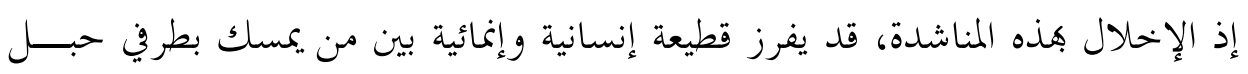
التو اصل، و ون هذه الشروط: أ. فهم الذات واحترامها: يشترط لنقد الذات حصول فهم الـــــات واحترامهـــا،

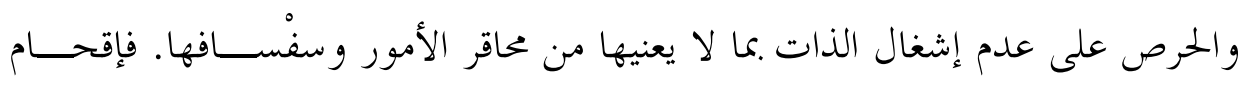
الذات في أشياء ليست من اختصاصها، سيفقدها الاحترام، ويبقيها في حلقة استهالاكية

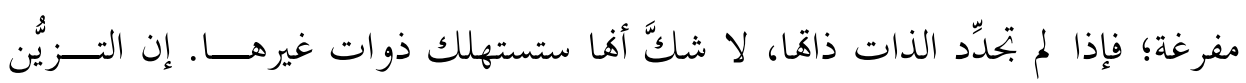

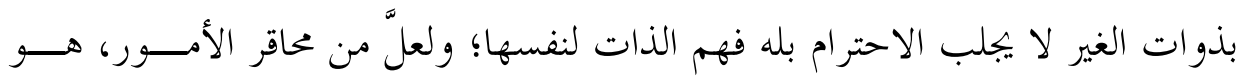

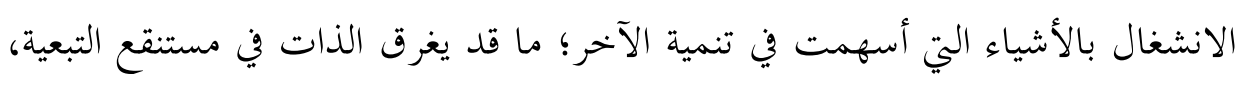

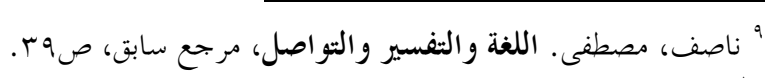

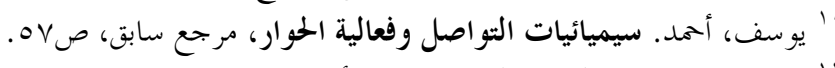

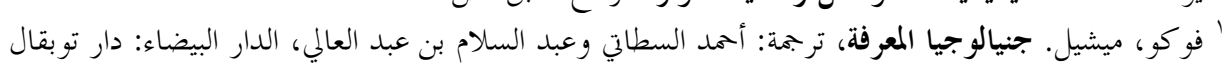

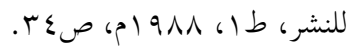


وتصير اللغة بين ذات التنمية، وذات التبعية لغة اتصال إنمائي، تفتقر إلى لغة التواصـل

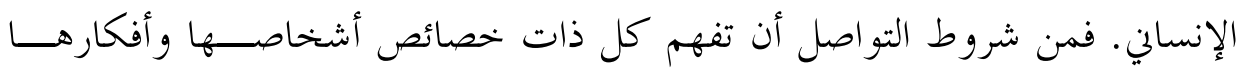

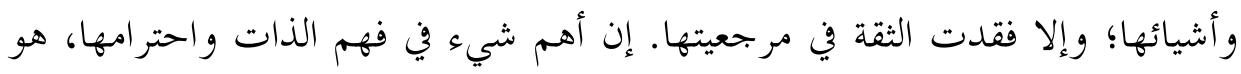

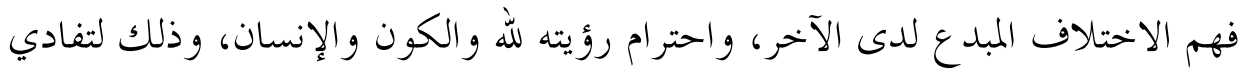

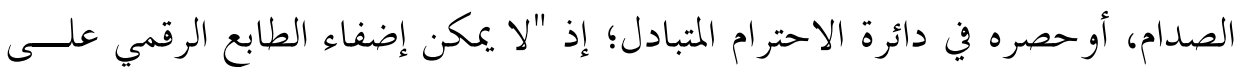

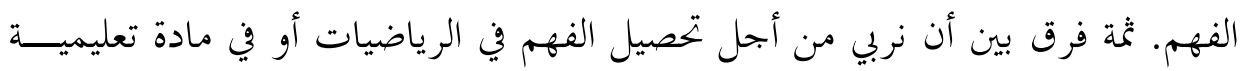

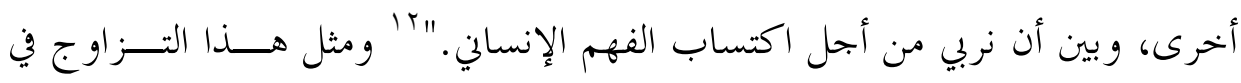

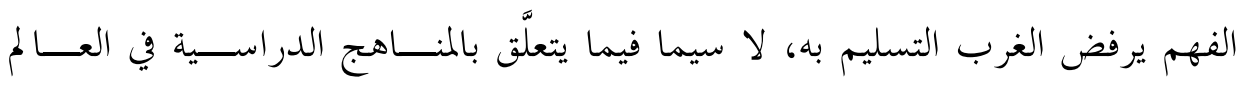

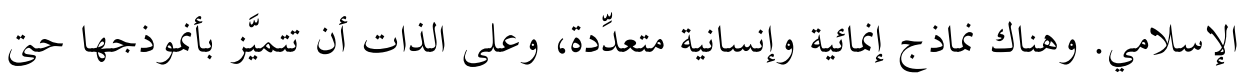

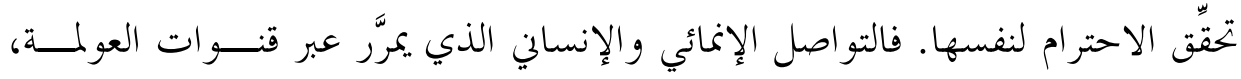

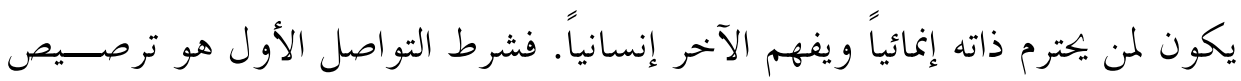

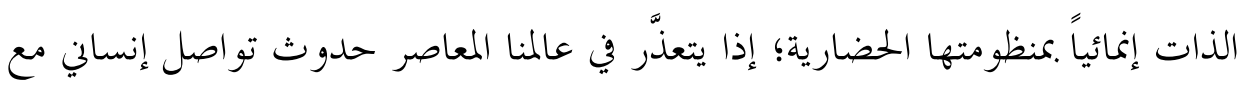
ذات متخلفة إنمائياً.

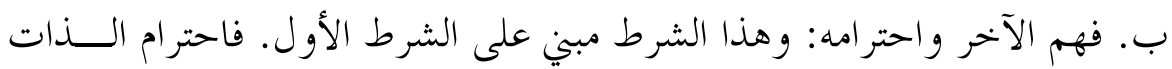

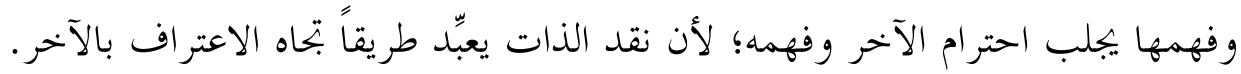

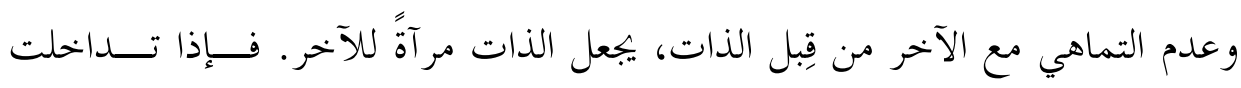

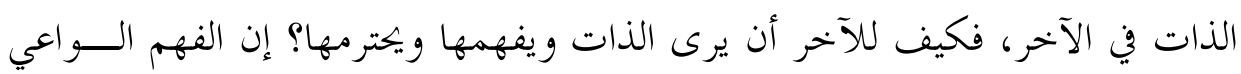

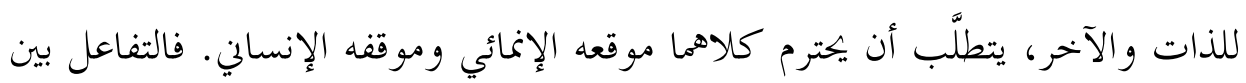

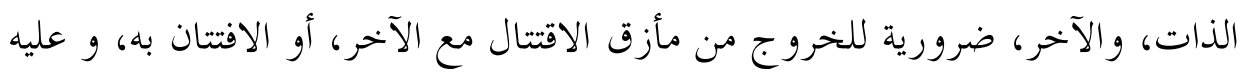

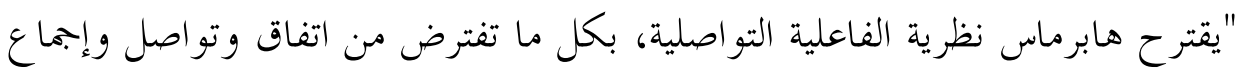

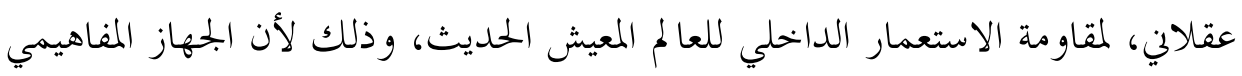

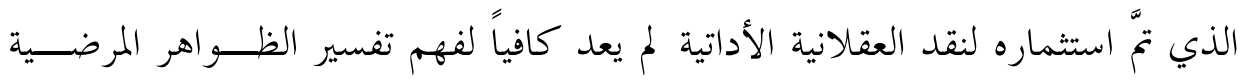
"' موران، إدغار. تربية المستقبل: المعارف السبع الضرورية لتربية المستقبل، ترجمة: عزيز لزرق ومنير الحهوجي،

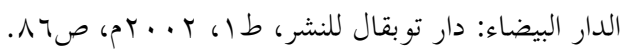




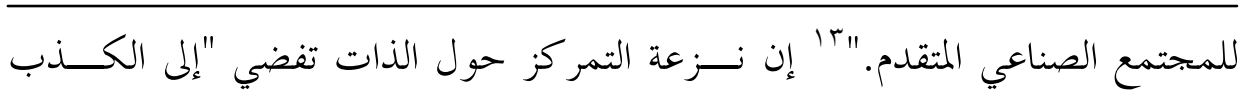

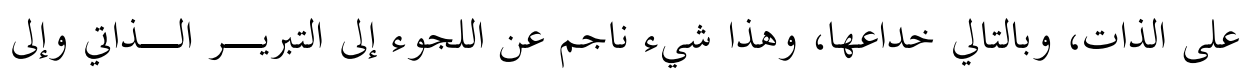

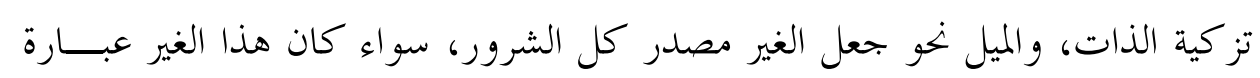

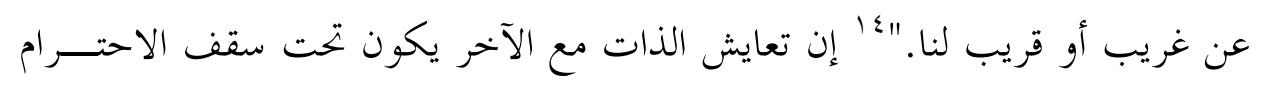

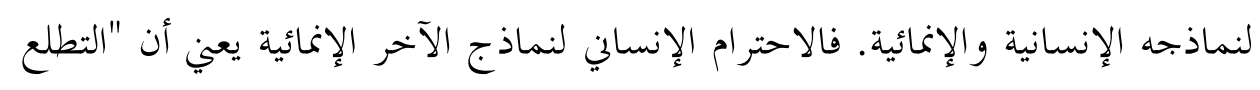

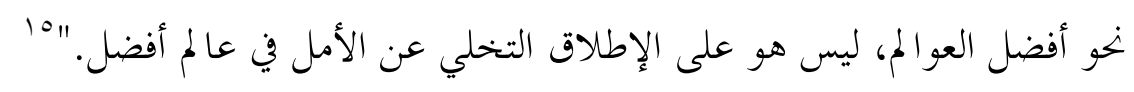
ت. التوظيف المتبادل للفهم والاحترام: لا بدَّ أن يُشعِر الآخرُ الذاتَ الأخرى، بأن

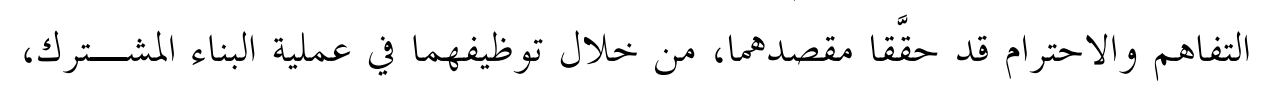
بحيث يُترجم ذلك باتِّحاذ خطوات جريئة وملموسة، تنقشع بداخلها ضبابية الرؤيسـة

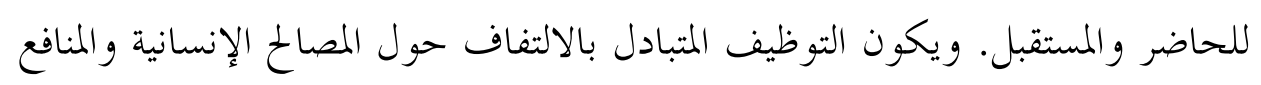

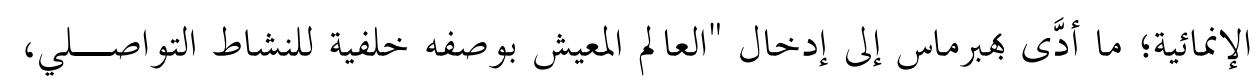

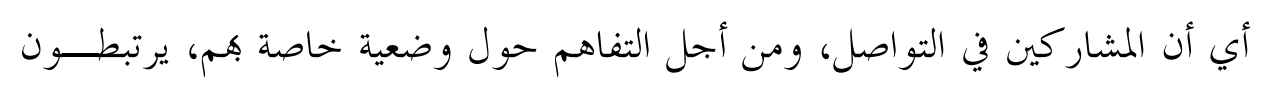

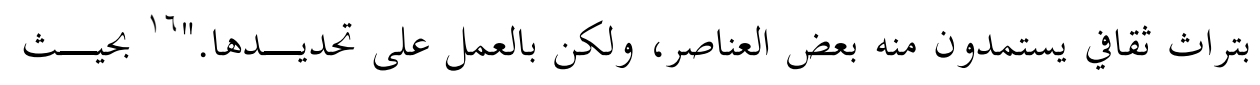
يكون تحديد هذه العناصر في إطار المسائل الإنسانية والإنمائية الوضعية المشتر كة. ث. تفعيل الإبحازات واستثمارها داخل هذا التوظيف المتبادل: لا شيء في التفاهم

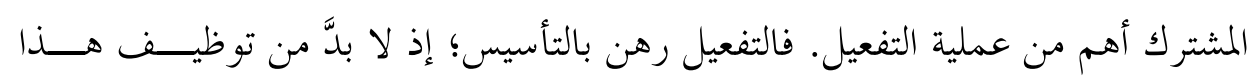

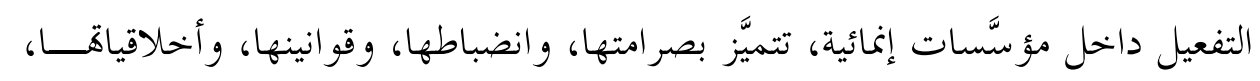

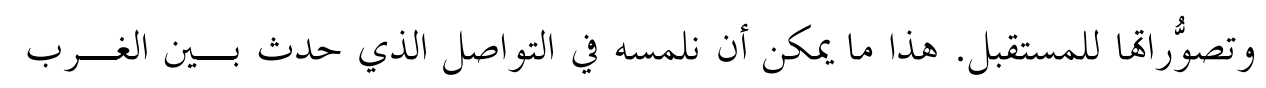

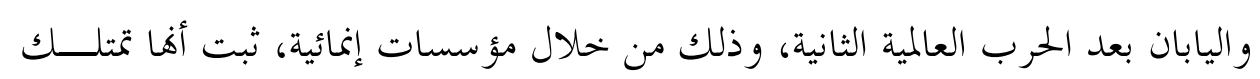
المقدرة على معالجة المسائل الكبرى التي تعترض طريقهما.

rا'فاية، حممد نور الدين. الحداثة والثواصل في الفلسفة النقدية المعاصرة: نموذج هابرماس، الدار البيضاء: أفريقيا

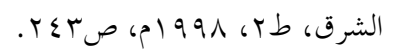

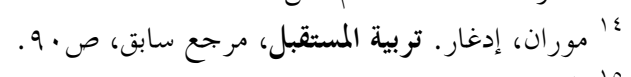

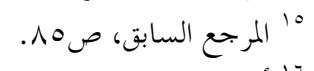
"1 أفاية، محمد نور الدين. الحداثة والتواصل في الفلسفة النقدية المعاصرة، مرجع سابق، صوه1 ا. 


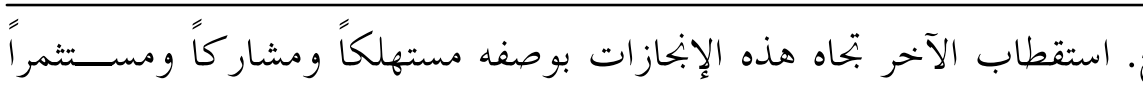

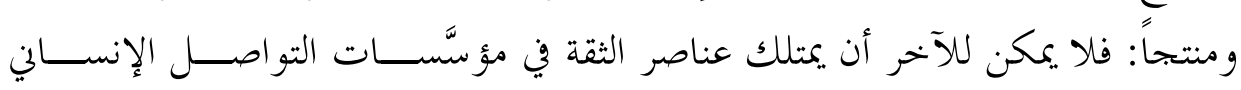

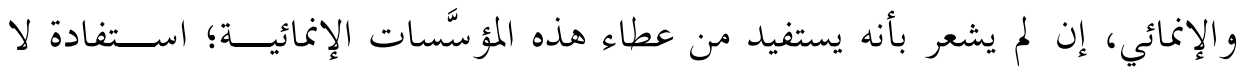

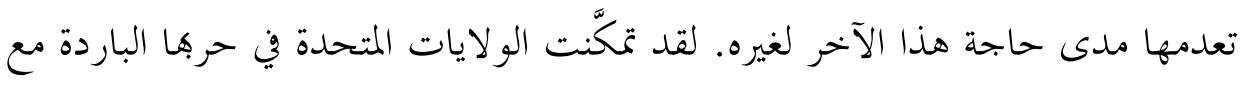

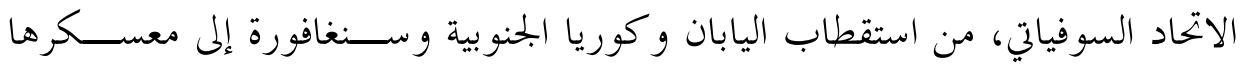

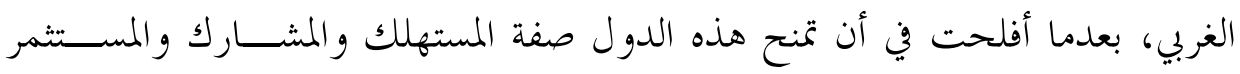

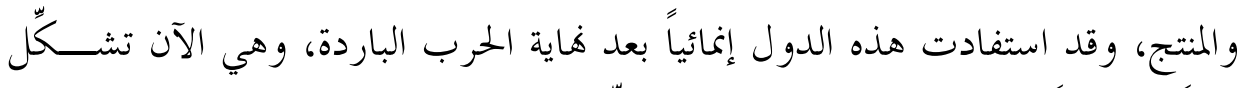
قطباً اقتصادياً، لا يمكن الاستغناء عنه في حلٍ مشاكل العالم الإنمائية. د. إشعار الآخر بأنه يمتلك المقدرة على أن يكون طرفاً مهمّاً في عملية التواصـل

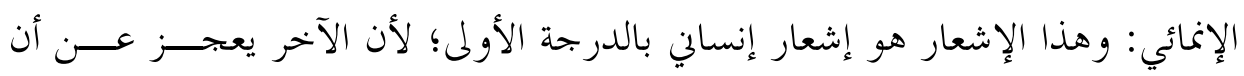

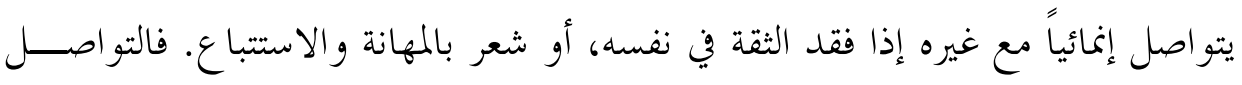

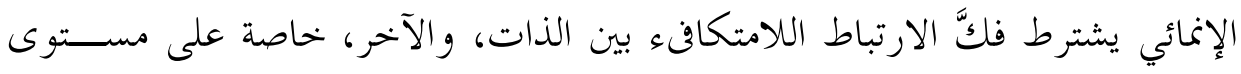

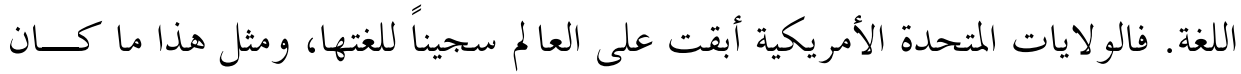

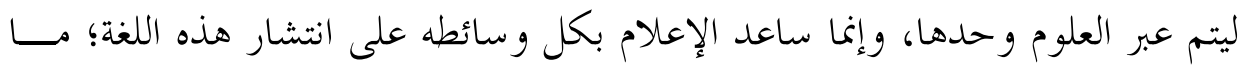

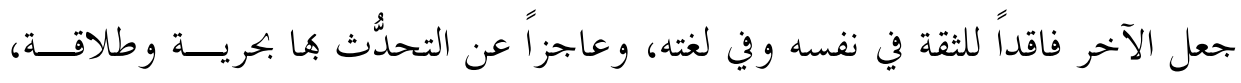
و الإبداع بوساطتها.

هـــ. إعطاء الفرصة للآخر للاعتماد على ذاته: وهذا يشــــل امتحانــاً عســــاً

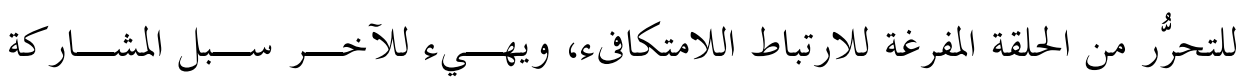
و المنافسة، وعرض البدائل الإنمائية.

و • ربط التوظيف الإنمائي بالاعتماد المتبادل: وهنا تتجلَّى حقيقة نقـــــ الـــذات،

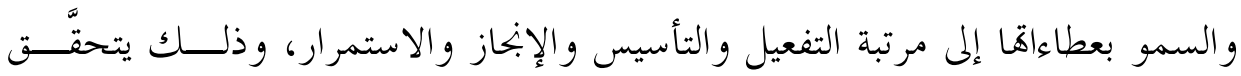

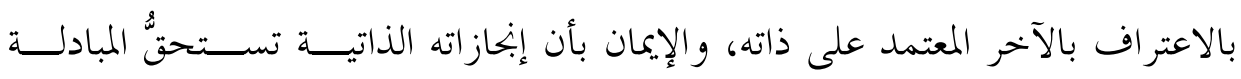

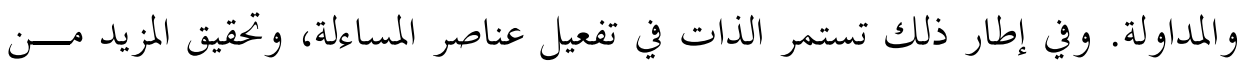
المو اقف المسؤولة بتحاه الأخلاق و الرسالة و العقيدة. 


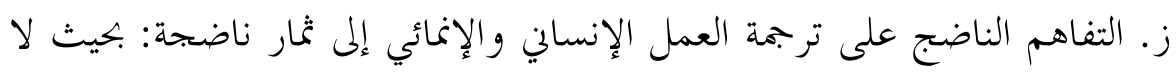

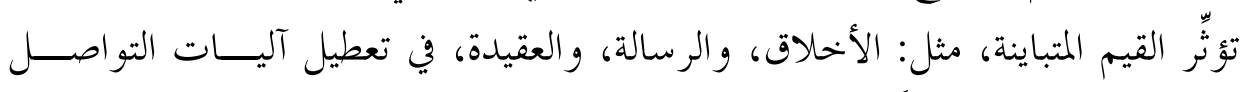

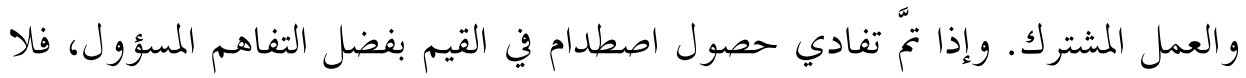

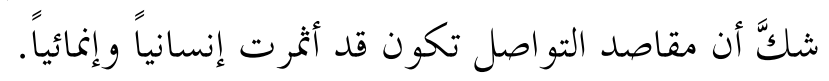

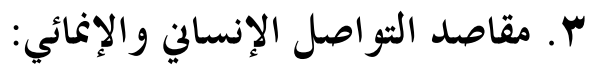

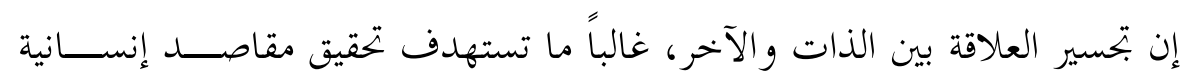

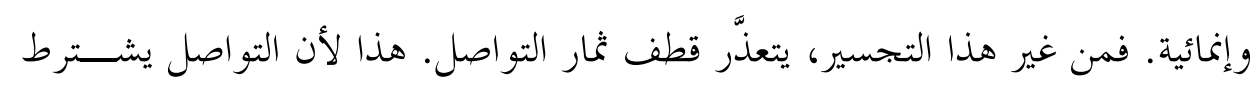

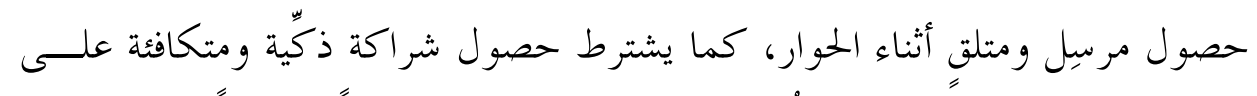

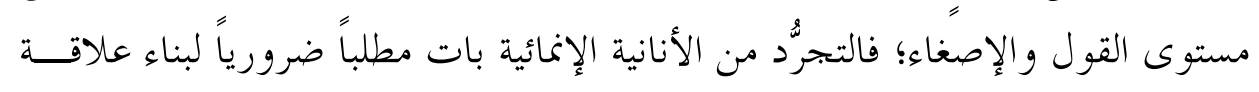
إنسانية متكافئة.

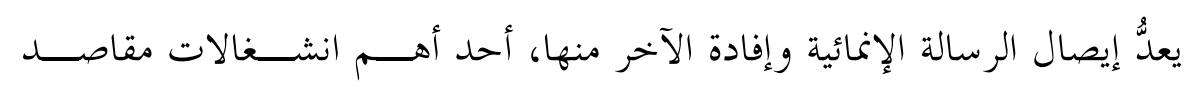

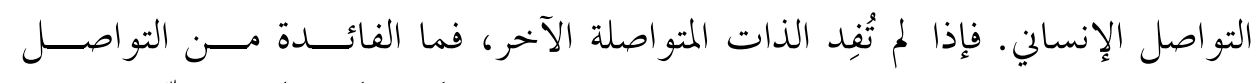

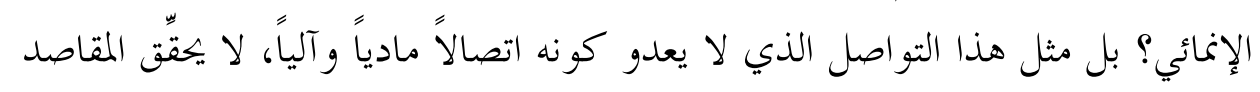

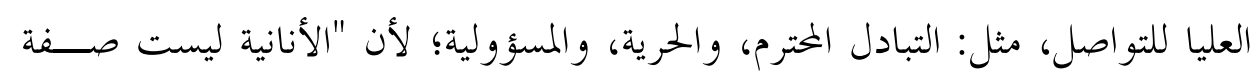

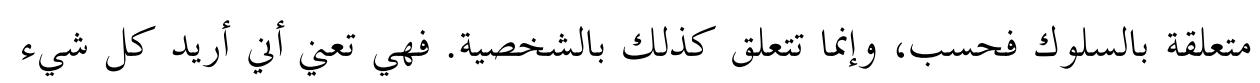

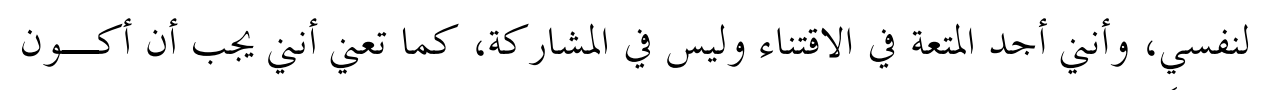

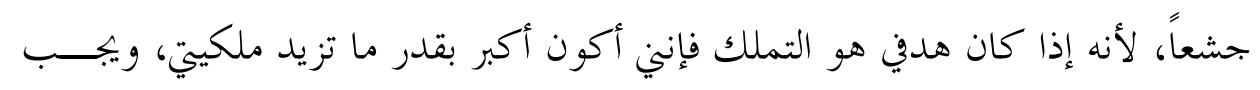

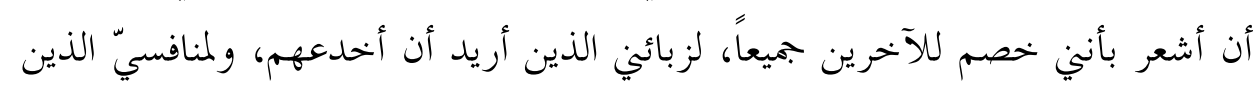

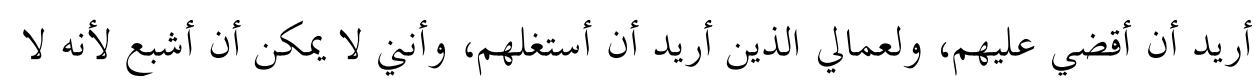

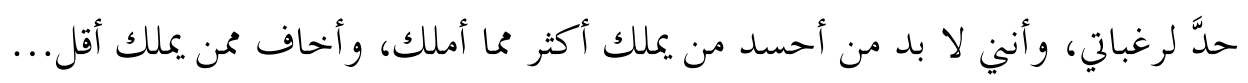

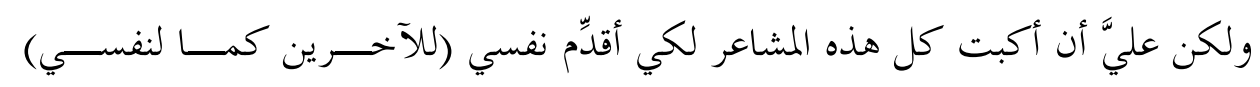

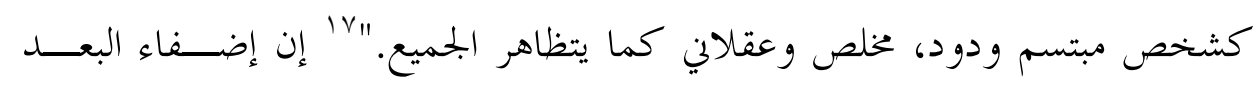

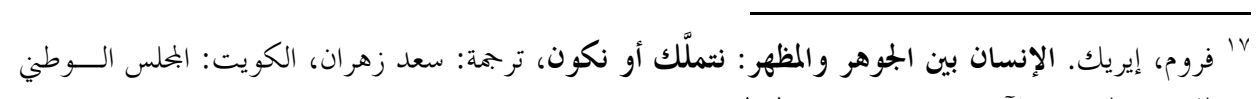

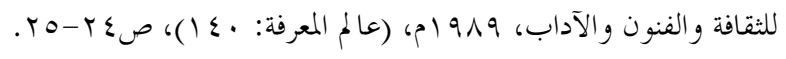


الإنساني على الفعل الإنمائي، هو الذي يجعل الإنسان يبتسم بصدق، ويعمل بإخلاص، و يتصرَّف برشد.

يشترط تحقيق المقاصد الإنمائية، تجريد المتحاورين من الأنانية الإنمائية، والتركيــز

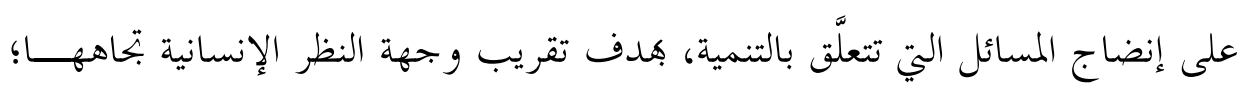
لأن مقاصد التواصل تتوخَّى المساواة لتعميم عناصر الإفادة. فمن غير مساواة في القول

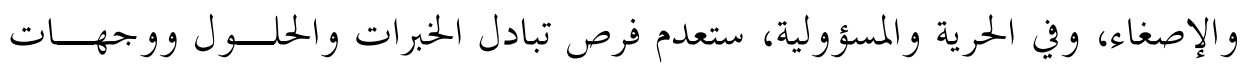
النظر السديدة.

و تتجلَّى أهمية الأبعاد الإنسانية للحوار، في أهـا تبقي المسائل الإنســـانية في إطـــار إنساني، يبغي تحقيق المزيد من التواصل الإنمائي؛ لأن المحاور هو إنسان، ويُفترَض منه أن

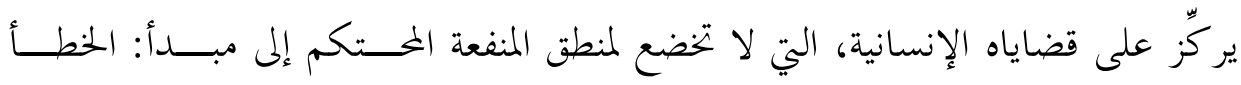

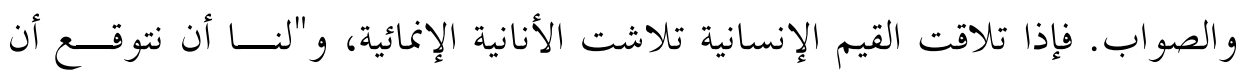
الاختلافات في عملية الفكر ستبدأ هي الأخرى في التلاشي. و وثمة شواهد في الحقيقــة تدل على حدوث تغيرات في الممارسات الاجتماعية، بل وتغيرات طرأت على الحالات الوقتية للتوجه الاجتماعي، وهو من شأنه أن يغير طريقة الإدراك الحسي و التفكير عند

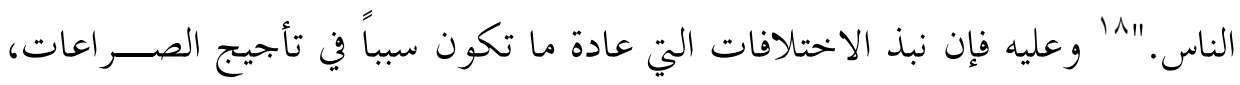
هي مقصد سامٍ من مقاصد التو اصل الإنساني والإنمائي.

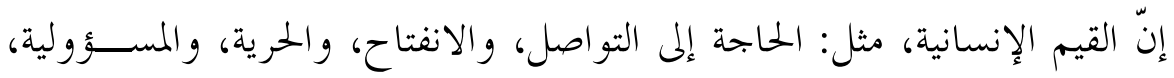

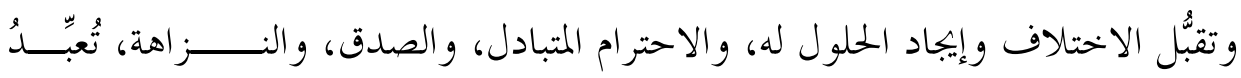

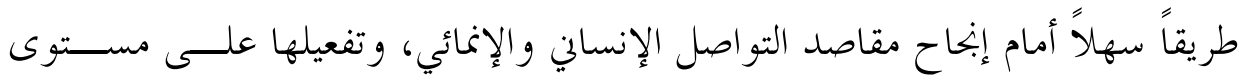

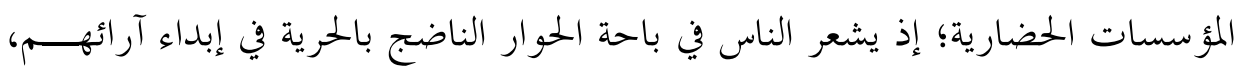
وعرض مقترحاهم. فالحوار يشكلّ أعلى درجة في النشاط التواصلي، ويعني ذلك أنه لم

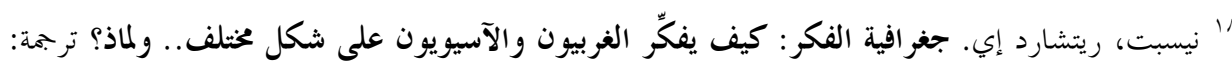

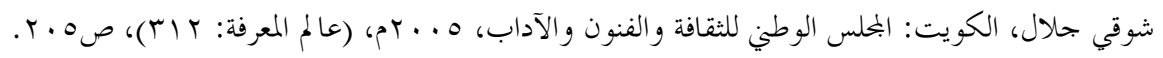




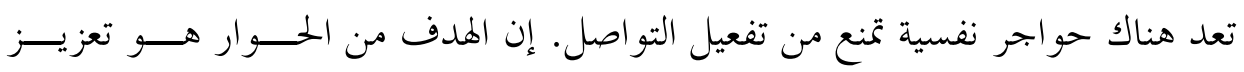

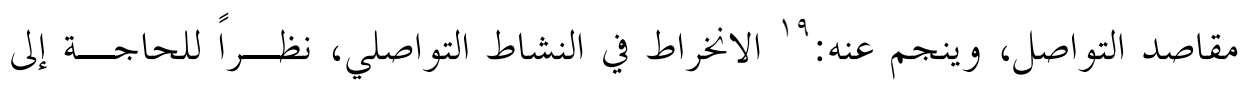

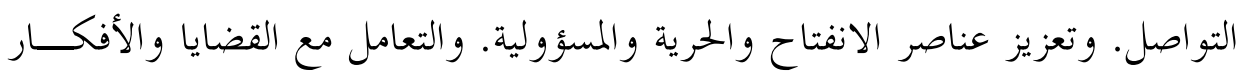

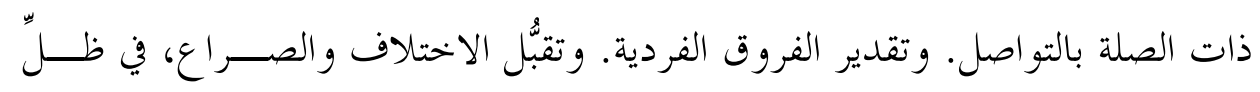

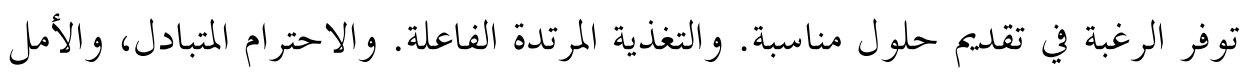
المفعَم، والثقة. والصدق والنــز اهة أثناء التواصل. و والموقف الإيجابي تحاه الفهم و التعلُّم.

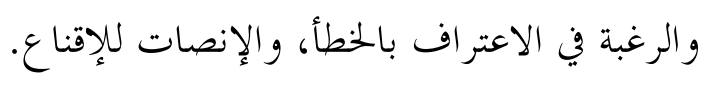

\section{ع ـ أخلاقيات التواصل الإنساني والإنمائي:}

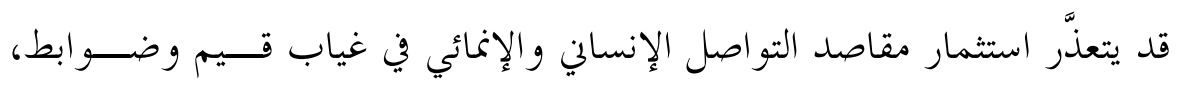

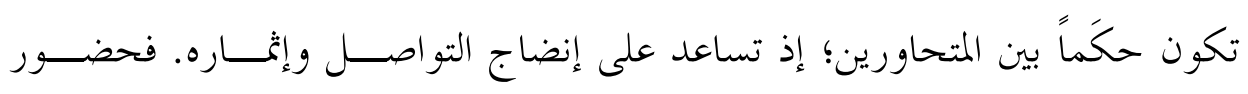

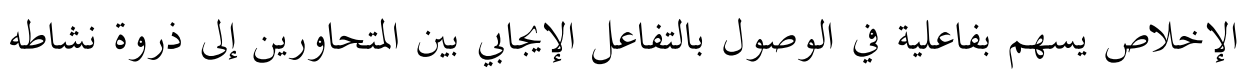

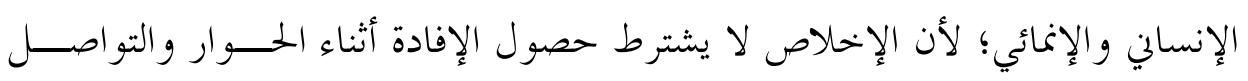

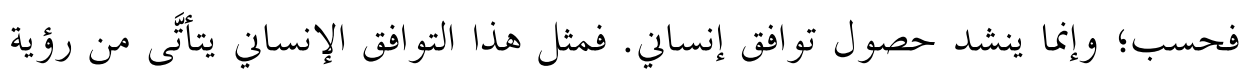

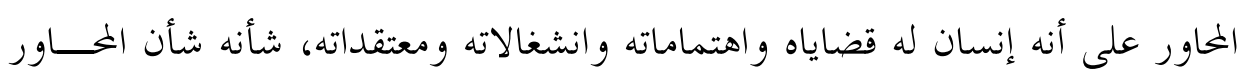

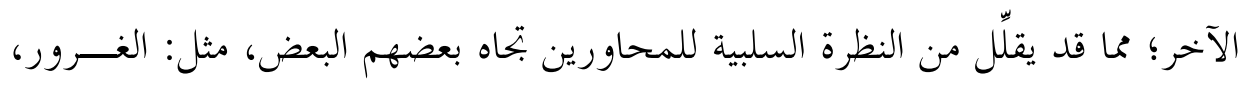

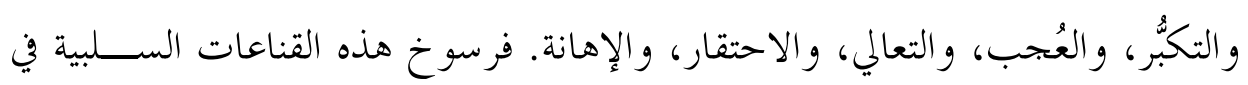

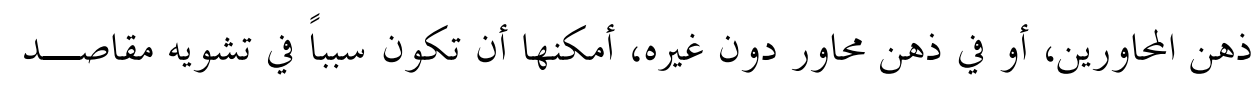

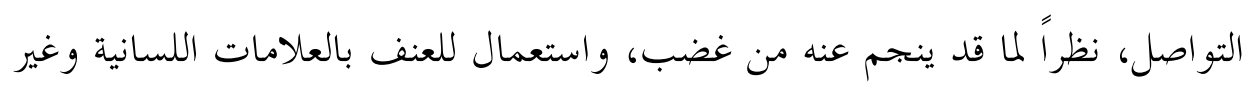

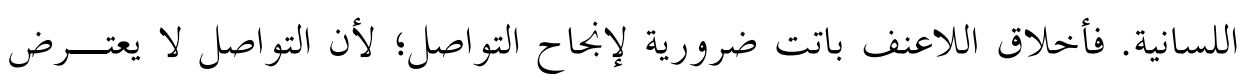

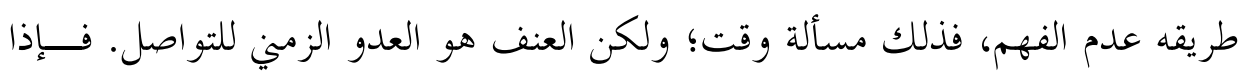

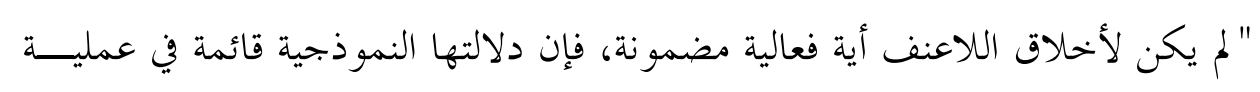

19 Johannesen, Richard L. Ethics in Human Communication, Illinois: Waveland Press, Inc, $3^{\text {rd }}$ ed, 1990, p 77. 


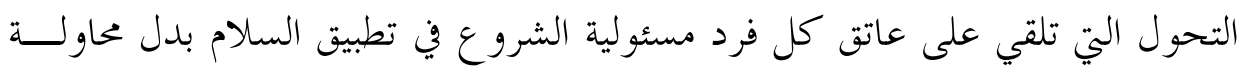

$$
\text { البحث عن الخطأ لدى الآخرين."r.r. }
$$

ينبغي الحرص في أثناء التو اصل على توظيف أخلاقيات وقيم وضوابط، تســـاعد على احترام الإنسان و الاقتر اب منه بالقيم الإنسانية التي تخاطب فطرتسـه، و بالوســـائل

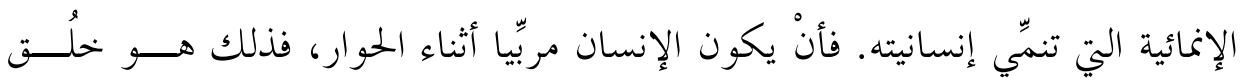

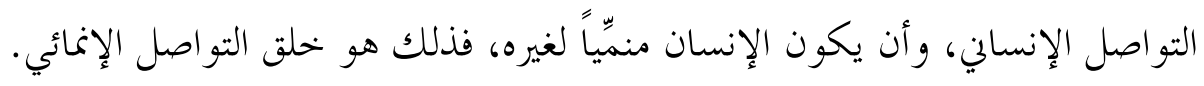
إن قاعدة: الإنسان أخ للإنسان، تشكلّ مدخلاً مهمًّا لربط الأخحلاق بالتواصـل الإنساني والإنمائي، و التي يُشترَط لنجاحها حصول النظرة المحترمة للإنسان، و التوظيف الرحيم للاختلاف، وإطلاق حرية الاختيار و المراجعة، وتعميم العدل، وبتريم الفساد.

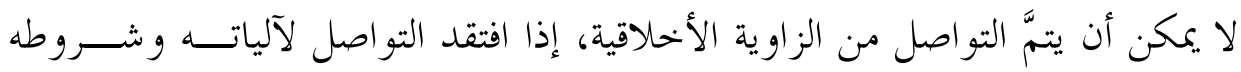
و مقاصده. إن حضور الأخلاق مشروط بحضور الاعتراف المتبادل بين الذات، والآخر. فالاحترام المتبادل يشكلّ اللبنة الأساسية في بناء أخلاقيات للتواصل الإنسائ والإنمائي،

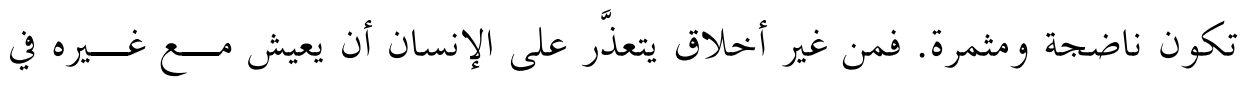
انسجام وأمان وسلام؛ لأن التواصل ينجح أكثر "في ظل إسهام الخبرة الأخلاقيسـة في إطالة عمر الحوار." "r" وعليه فإن هناك أسباباً للتو اصل، ودعائم متينة للحوار، تتأتى من أن معرفة الإنسان لنفسه، ومن هنا نعتقد بوجوب توفر هذه الأخلاقيات من أجل حســوار

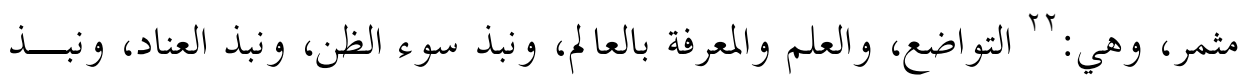
العنف، و حسن الإصغاء، و التسليم بحرية الآخر.

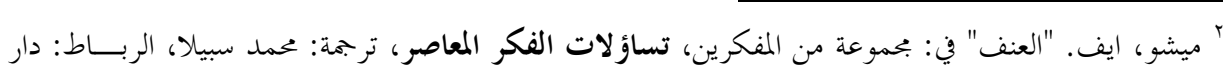

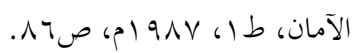

${ }^{21}$ Littlejohn, Stephen W. Theories of Human Communication, London: Thomson Learning, $7^{\text {th }}$ ed, 2002, p 13.

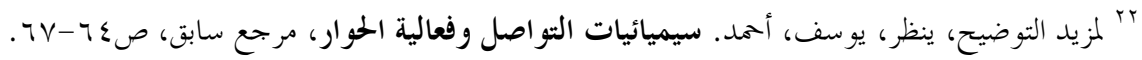




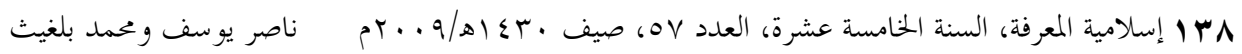
ثانياً: الضمانات القر آنية للتو اصل الإنساني والإنمائي مع الآخر، والحففاظ على إرثه الحضاري لقد غاب عن فلاسفة الغرب -بوصفهم علمانيين - أن التواصل يشترط الضمان؛

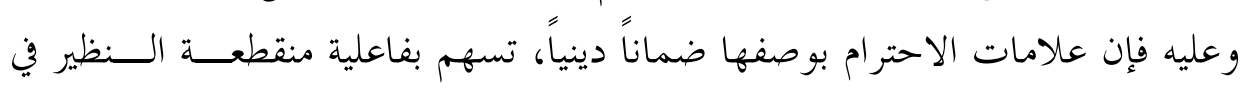

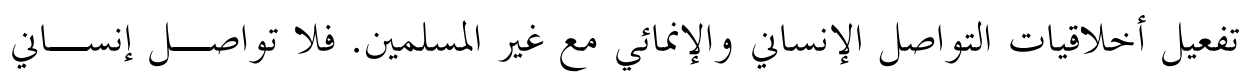
و إنمائي من غير ضمان ديني.

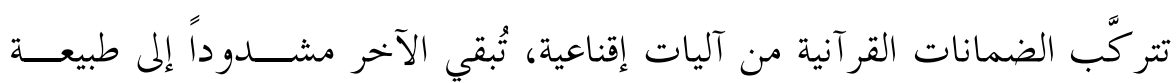

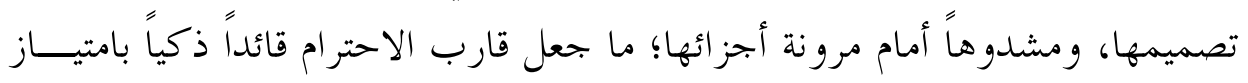
لر كب التو اصل؛ و لا غرابة في ذلك، فالحضارة الإسلامية مشهودٌ لها ببراعتها الفعلية في التسامح مع الآخر واحترامه، نظراً لما تبسطه للآخر من قيم عملية، تدفعها دفعـاً إلى الى

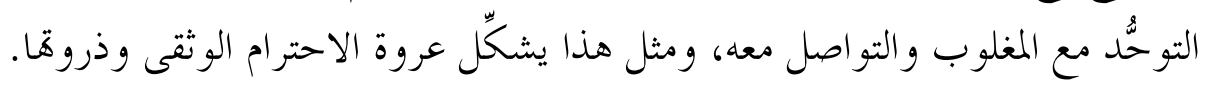
تُعَدُّ الضمانات القر آنية الآتي ذكرها، مثل الاحترام و تبعاته، طريقاً مشروعاً لتفعيل آليات التو اصل الإنساني و الإنمائي و شروطه و وقاصده و أخحلاقياتــه، و واســتثمار ها في

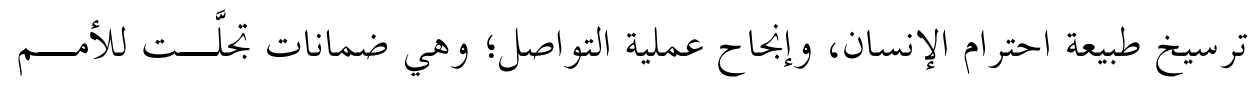
المغلوبة من خلال الصورة الحسنة للفاتحين، قبل أن يستكشفو ا حقيقتـــها في كتــاب المسلمين.

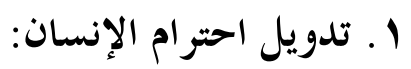

لا شكََّّ في أن طبيعة الاحتر ام تختلق ثمرة التفاعل. أََّّ ليس الدين الإسالامي يحتـــرم

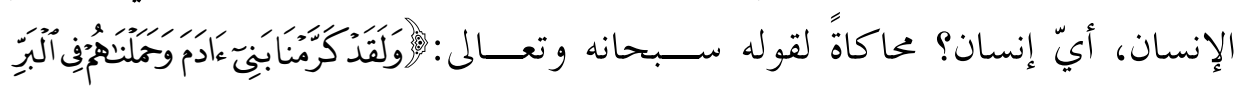

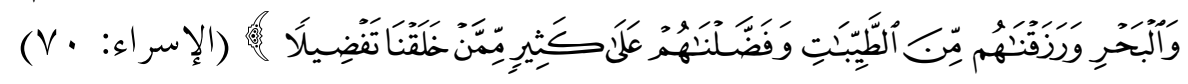

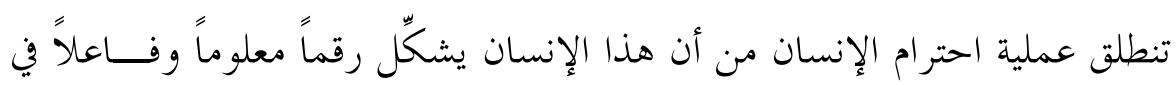
معادلة الحضارة الإنسانية. فالإخلال هذذا الرقم الفاعل هو إخلال بالتر كيبة الحضارية،

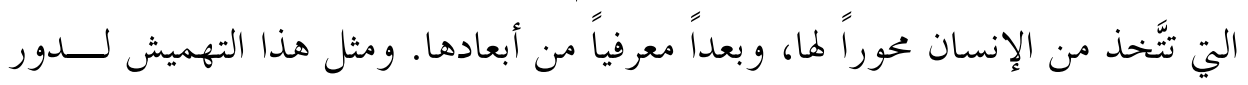


الإنسان في عملية الترصيص الحضاري، هو حالة مترسِخة في قلب الاستعمار الــذي أصابه الصدأ، و اتَّخذت منه الحضارة الغربية طريقاً لاستغلال الأمهم المغلوبة على عتلى عقلها.

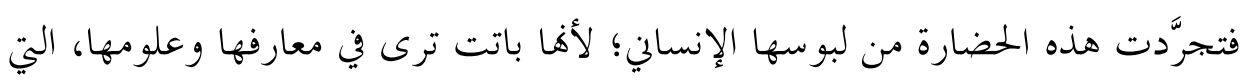

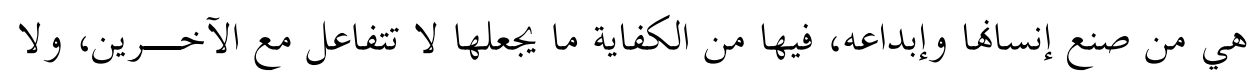

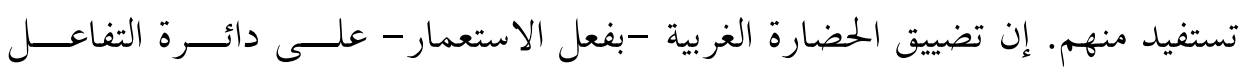
والإفادة، ساعد على توسيع مساحة اللا احترام والإبادة.

\section{r. التوظيف الرحيم للاختلاف:}

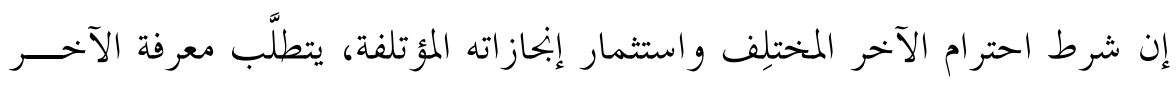

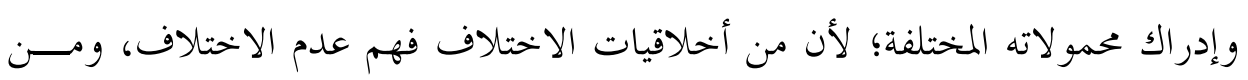

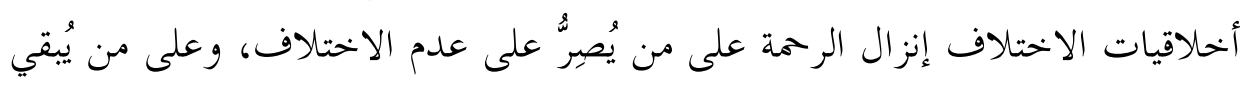

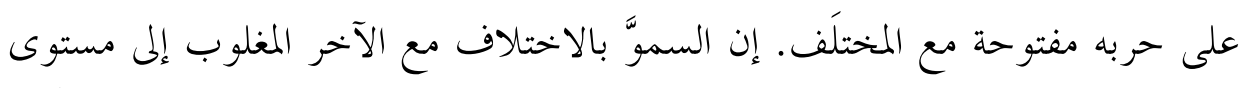

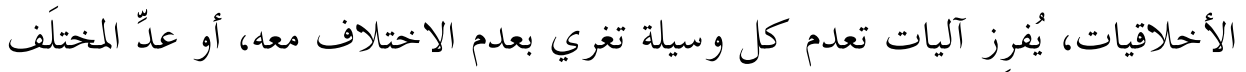

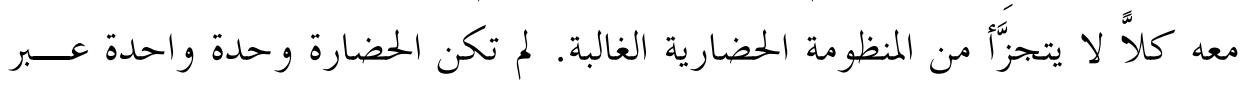
التاريخ؛ بل الحضارة حضارات، و الناسوت اختلافات، ومن هنا تستقي الأفكار محلِّتها

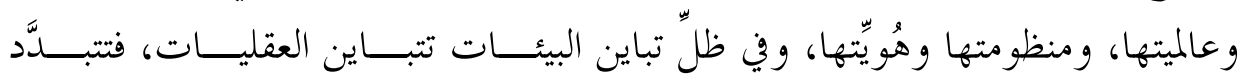

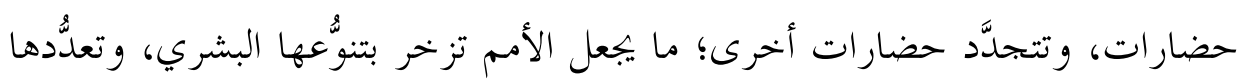
اللغوي، وتلوُّها العقدي.

لقد حازت الحضارة الإسلامية قصب السبق في إدراك حقيقة البنيـــة الحضـــارية

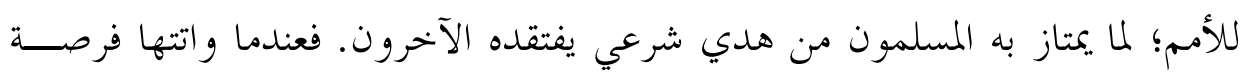

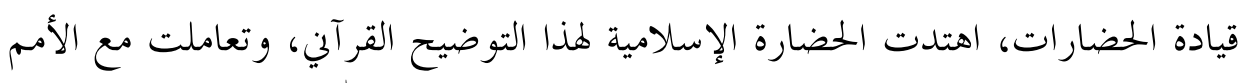

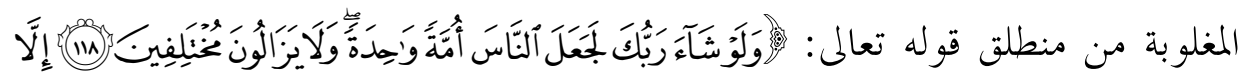

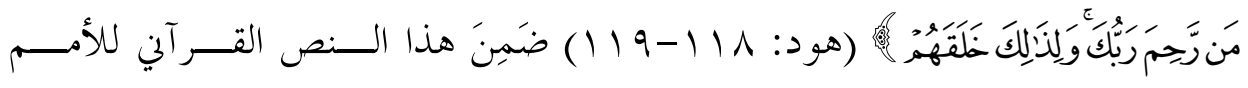

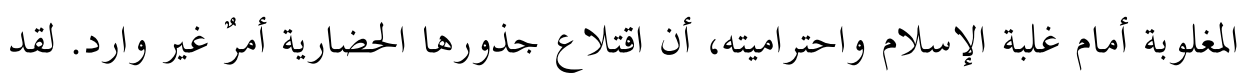

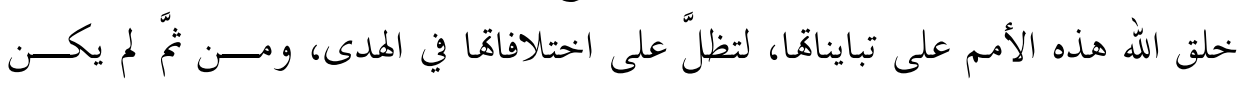




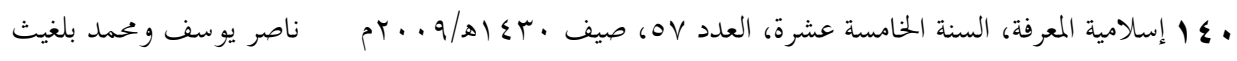

للفتح الإسلامي الرحيم -حضارياًا- أن يرفع عصا العذاب، كما فعل أشياع القوَّة من زبانية الاستعمار .

تشكل رحمة الاختلافت بنية الفتح الإسلامي، اليت استقرَّت في سويداء الحضــــارة

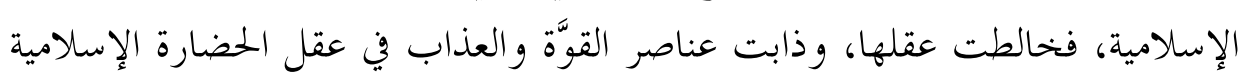

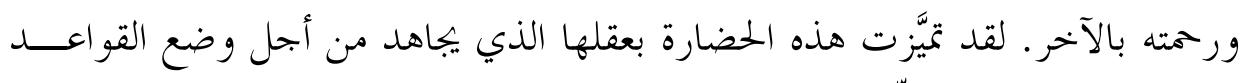

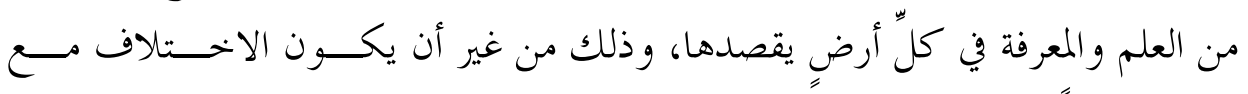
المغلوب سباً في استئصال إرثه الحضاري، أو التشكيك في منظو مته التاريخية.

إن إرساء دعالم الاختلاف بعلم لا يأتيه الباطل من بين يديه، مصداقاً لقوله تعالى :

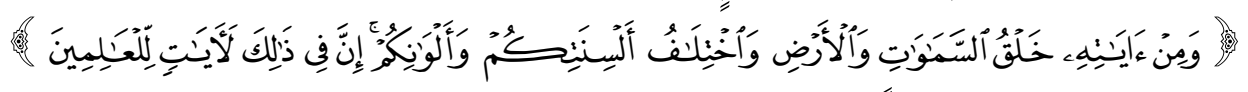

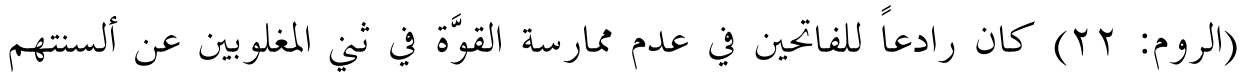
و معتقداتهم، و كان ذلك أيضاً مثابة الضامن لمؤلاء بأن العذاب لن ينال أجسادهم و حضارهم؛ لأن العذاب ليس من إنسانية الصفح الحضاري، وإنما هو من حيوانية السفح الاستعماري.

\section{ب. إطلاق حرية الاختيار و المر اجعة والنقد:}

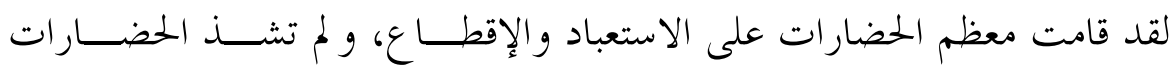
العريقة عن هذا المسلك، مثل: المضارة الصينية، و المصرية، و الفارســية، و الرومانيـــة،

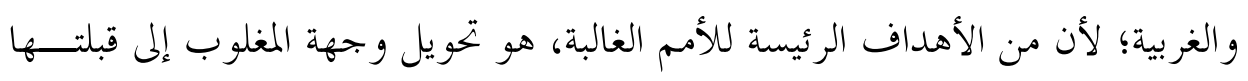

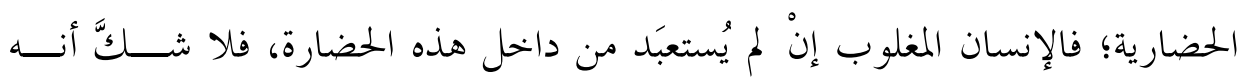

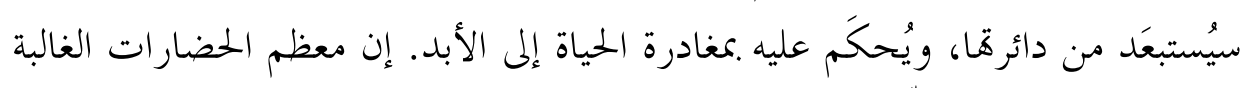

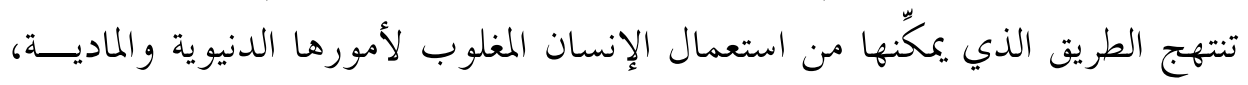
وهي إن أرغمته على اعتناق ديانتها؛ فإن و لاء هذا الإنسان المغلوب لهذا لها الدين سيكون

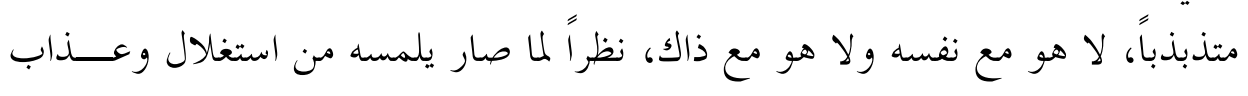
وتميش وقمع وإقصاء. 
و خحلافاً لما سبق الإشارة إليه، بشَّرت الحضارة الإسلامية بحرية الاختيار لـــــين،

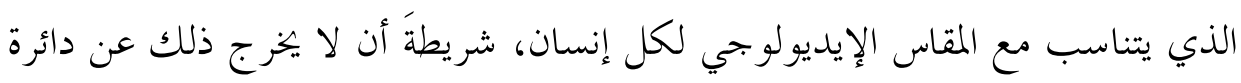

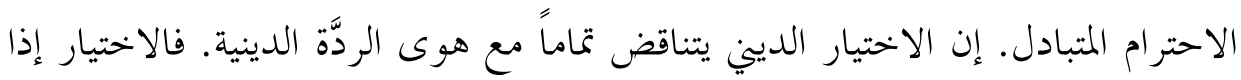

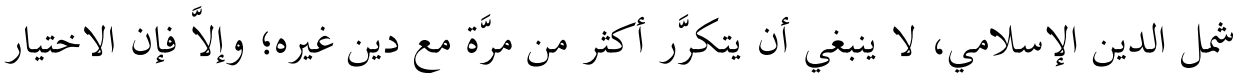

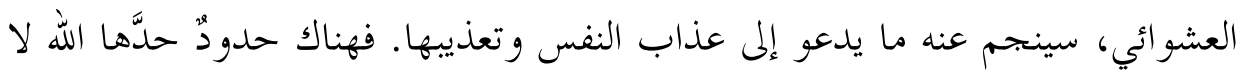
يمكن التلاعب هها، و الاختيار إزاءها.

لقد ضمِنت الحضارة الإسلامية بفتوحاها للأمم المغلوبة حريـــة الإبقـــاء علــى

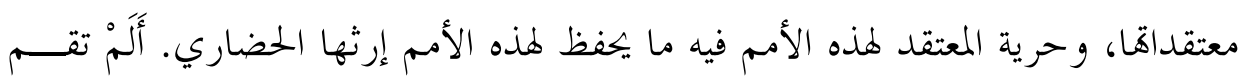
الحضارة الإسلامية على أرضية الاختيار الديني من أول يوم ابتذرت فيه بذرة الــلـعوة

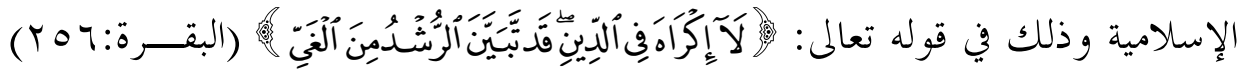

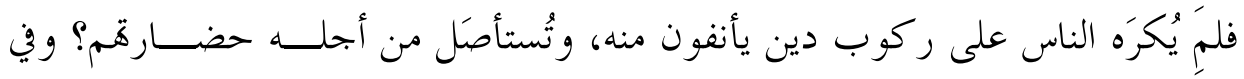

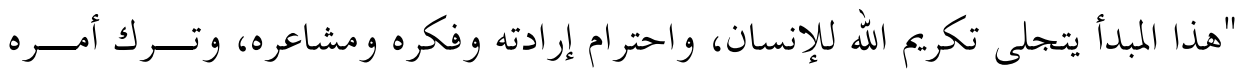
لنفسه فيما يختص بالهدى و الضلال في الاعتقاد وتحميله تبعة عمله و حساب نفســهـ.. و هذه أخص خصائص التحرر الإنساني.. التحرر الذي تنكره على الإنسان في القـــرن

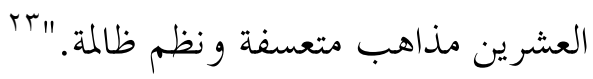

إن حرية الاختيار و المر اجعة والنقد مضمونة حضـــارياً إذا جـــاءت في لبوســــا الإسلامي، فهي سبيل الحضارة الإسالامية لتفعيل المعاني السامية لاحترام الآخر المختلف

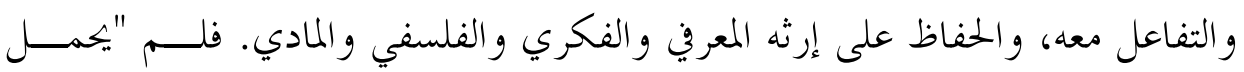

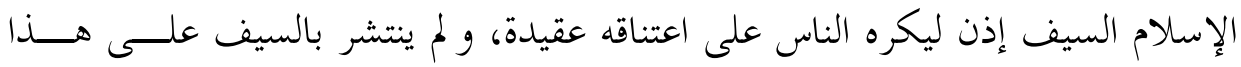

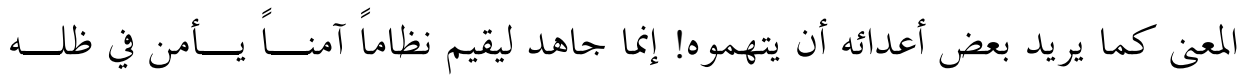

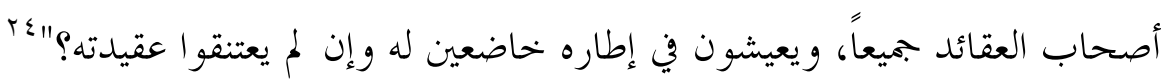




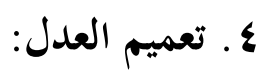

يشكلّ العدل أهم القيم الرئيسة في الإسلام، ولا شكَّ أن جميع الأمم دون استثناء

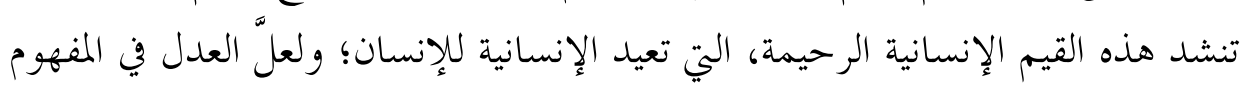

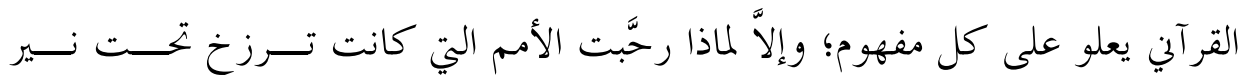

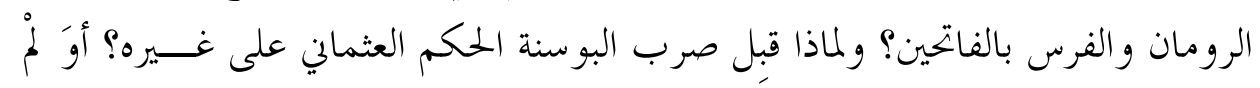

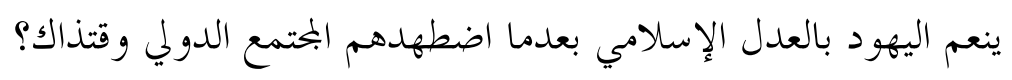

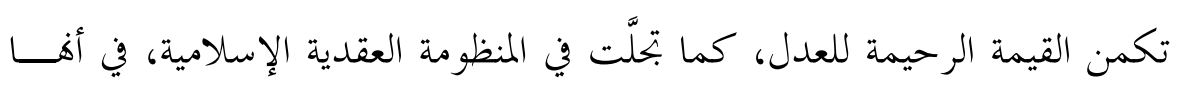

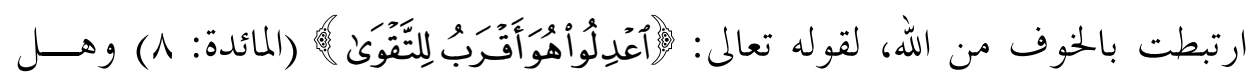

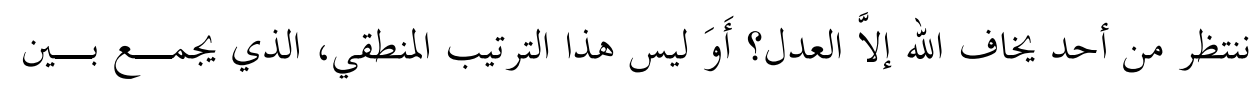

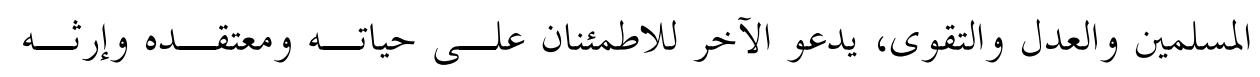
الحضاري؟

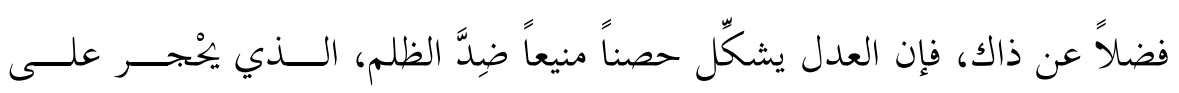

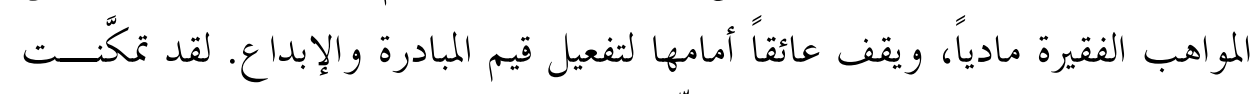

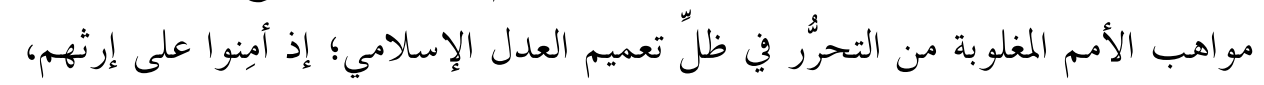

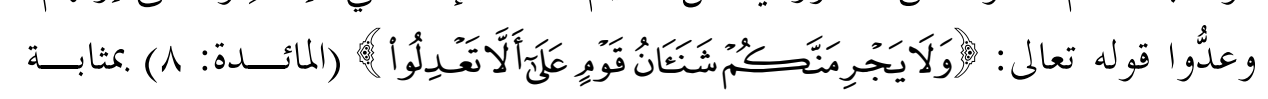
رسالة لإصصلاح وليس للإفساد.

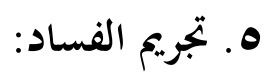

ما من شكٍِّ في أن الإسلام جاء لِيتََّّ مكارم الأخلاق، وليس للإفساد في الأرض.

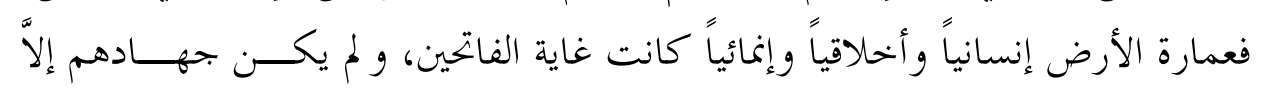

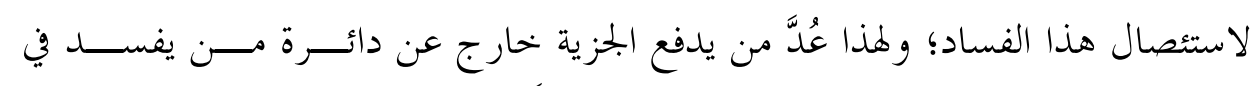

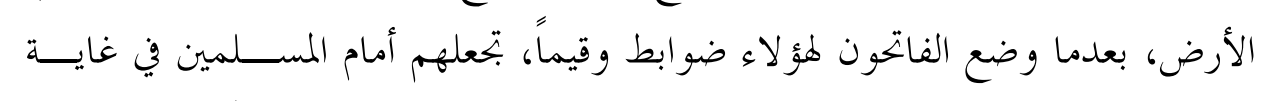

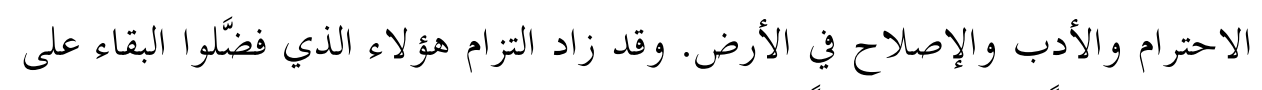

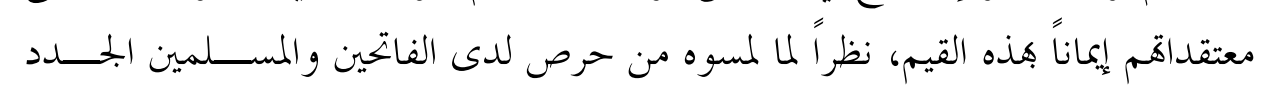




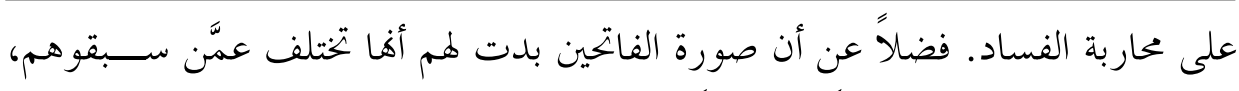

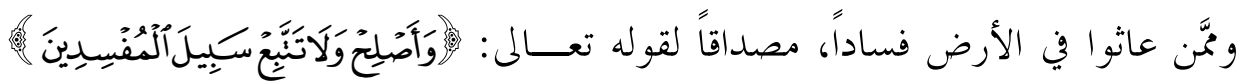

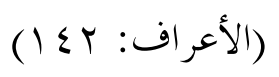

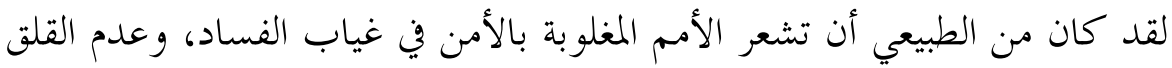

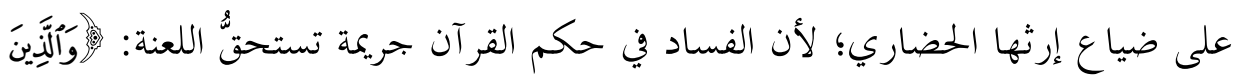

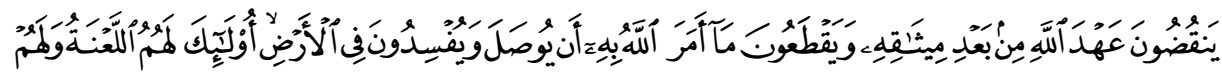

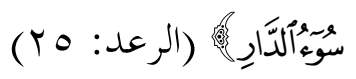

\section{ثالثاً: أهَّيّة التواصل الإنساني والإنمائي مع الآخر في تجليّات الحضـــارة الإســلامية}

الغالبة

لا نختلق أمراً جديداً ومن تُّ لا نرى شيئًا جديداً، إذا ما قلنا أن الفتح الإســلامي

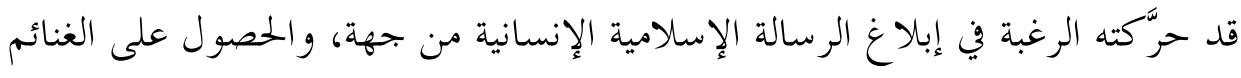

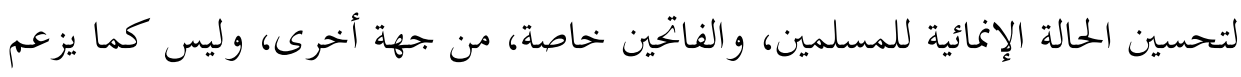

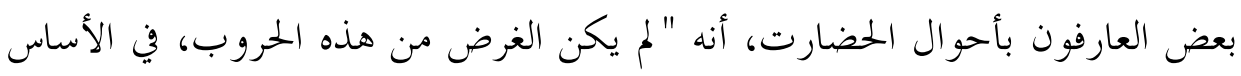

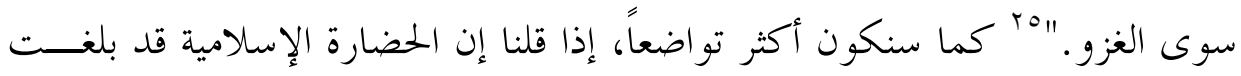

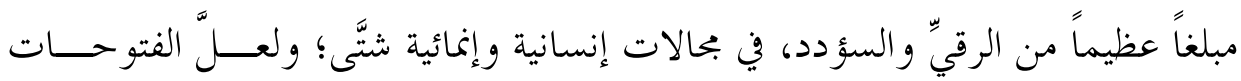

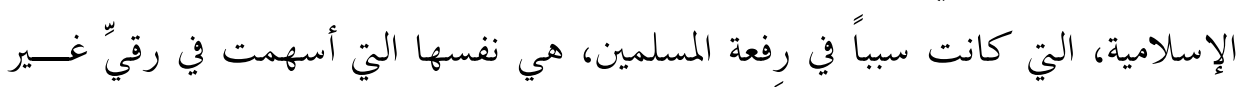

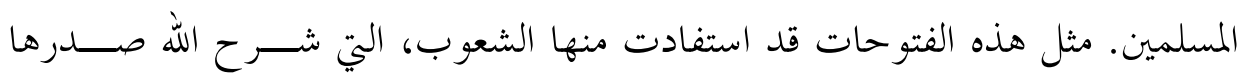

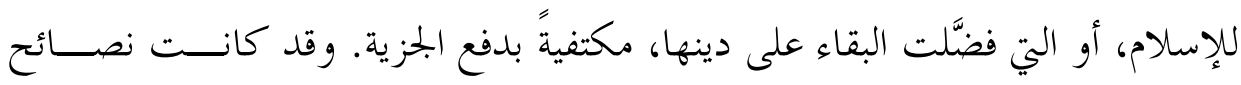

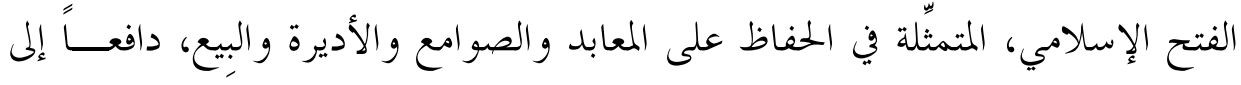

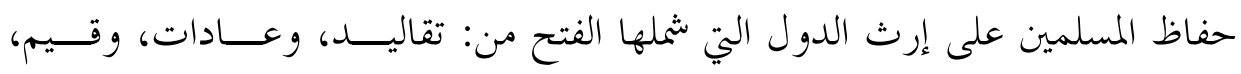

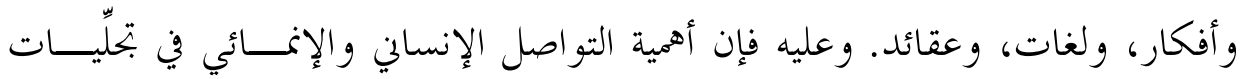

Pُ برّوي، إدوار . تاريخ الحضارات العام: القرون الوسطى، ترجمة: يوسف أسعد داغر وفريد م. داغر، بيروت-

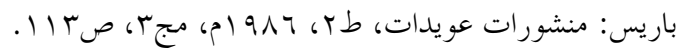




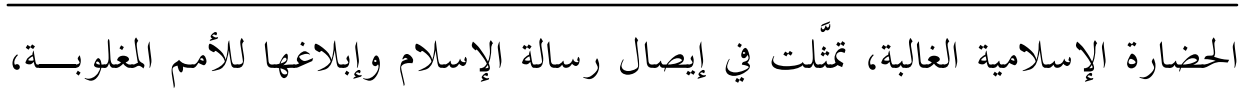
وقد تمَّ ذلك من خلال احترام الإنسان، وتنمية قدر اته الروحية والمادية.

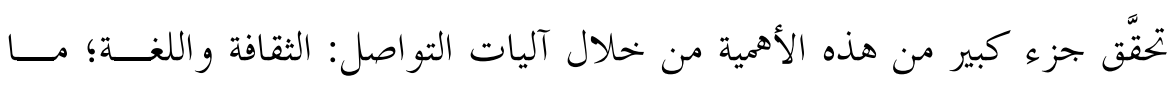

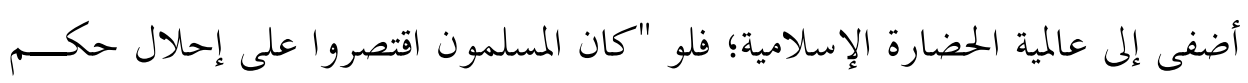

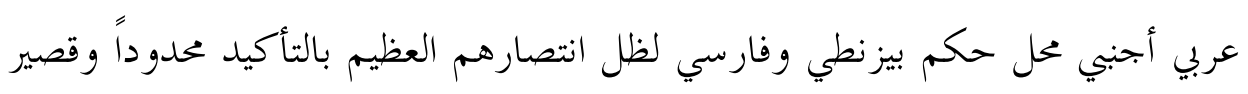

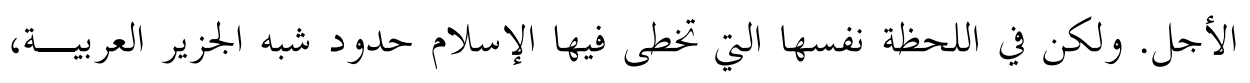

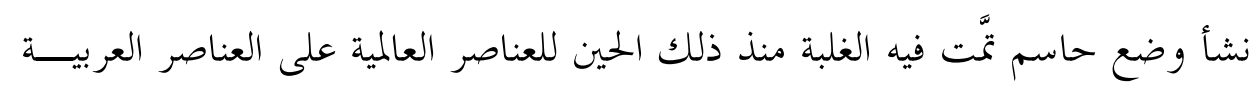

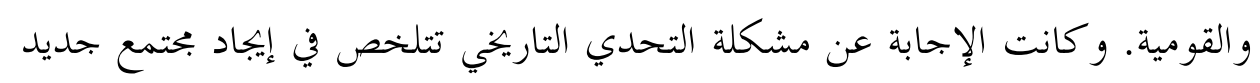

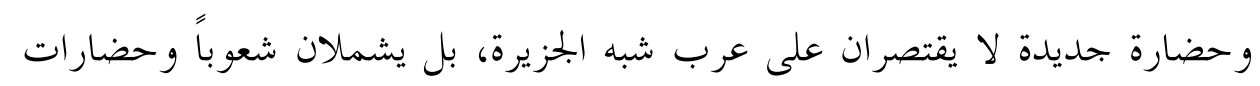

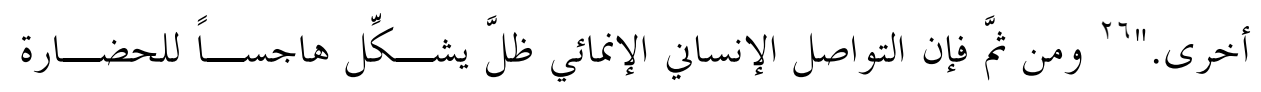

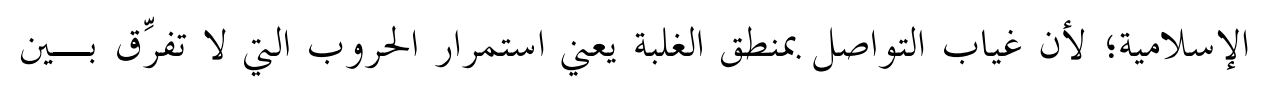

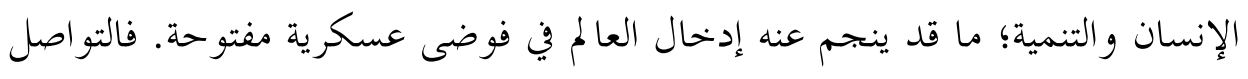

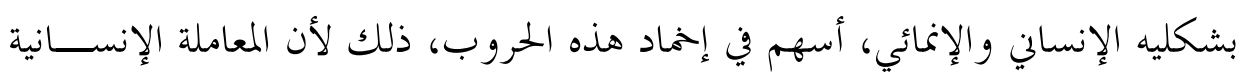

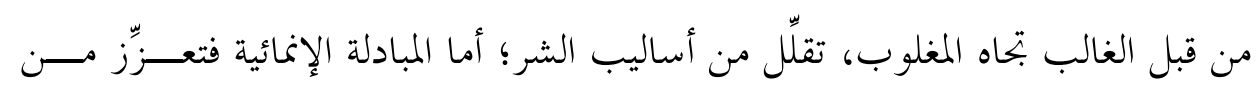
الشراكة الإنسانية.

لا نرى أن الثقافة الإسلامية شكَّت عائقاً أمام المسلمين للتواصل مع غيرهم، بــل التصل

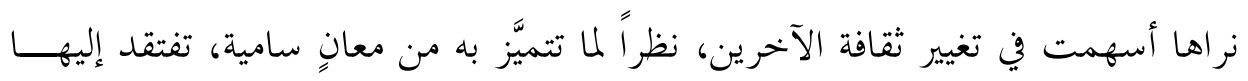

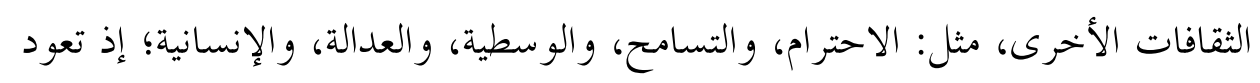

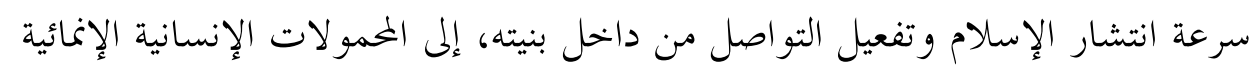

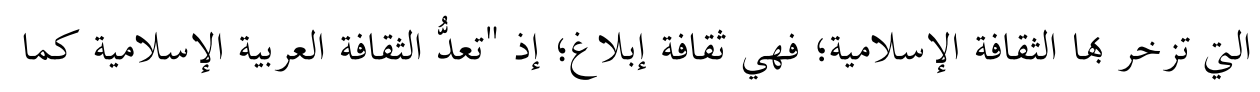

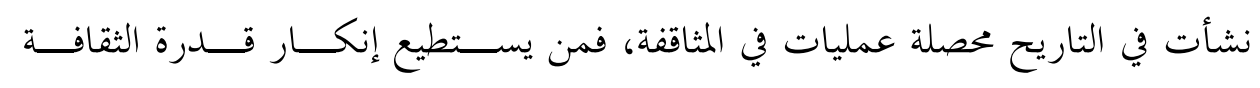

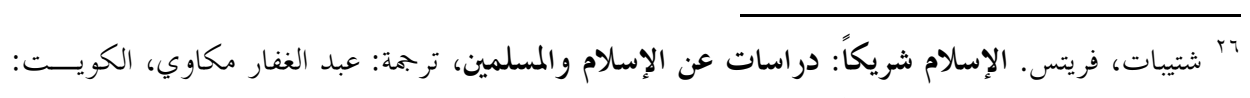

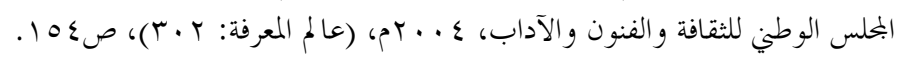




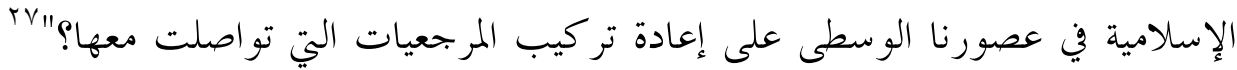

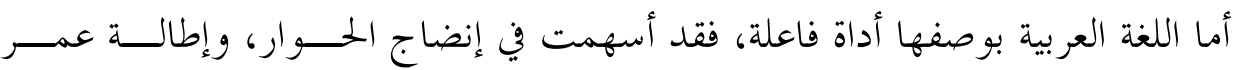

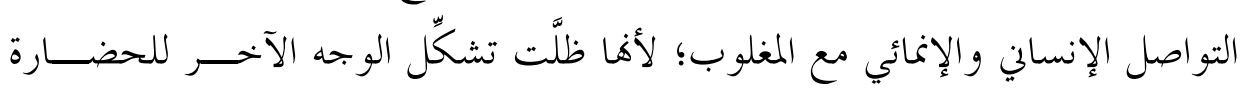

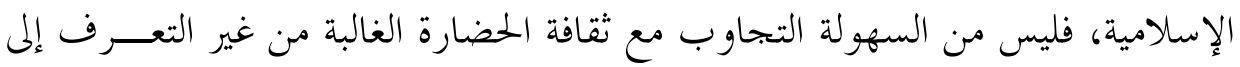

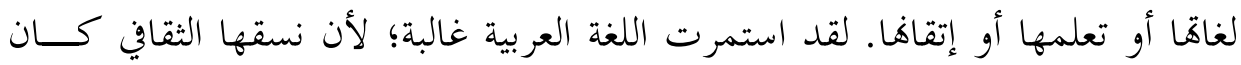

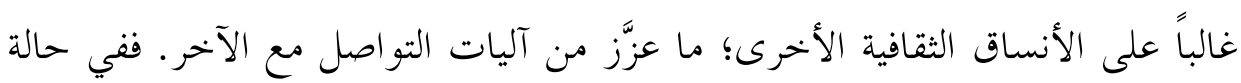

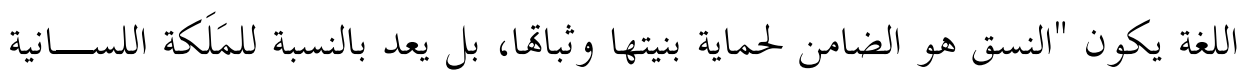

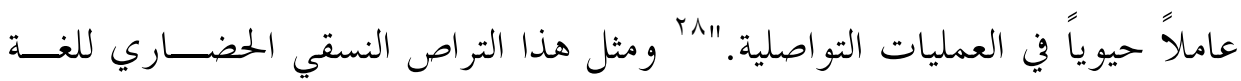

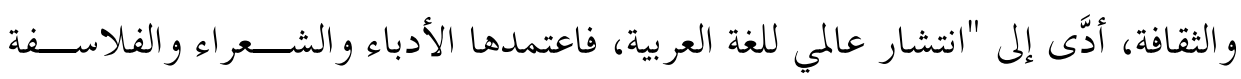

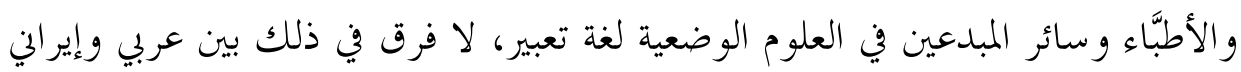

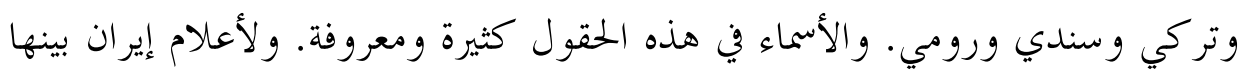
حصَّة من الأسد." و وناي وروبي

من جهة أخرى، غيَّرت عظمة الفتح الإسلامي نظرة الآخرين غـير الصــحيحة

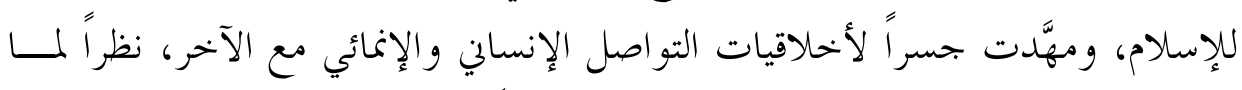

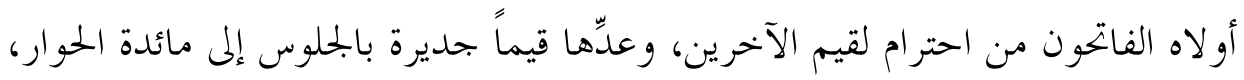

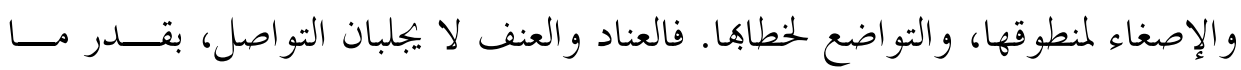

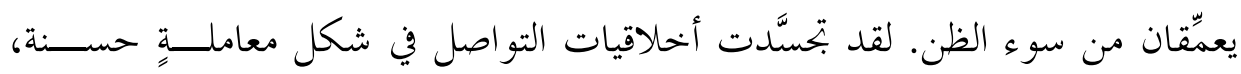

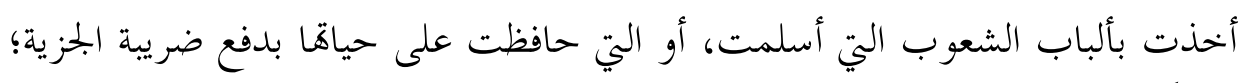

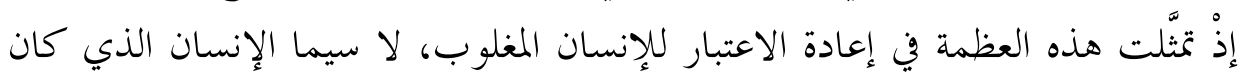

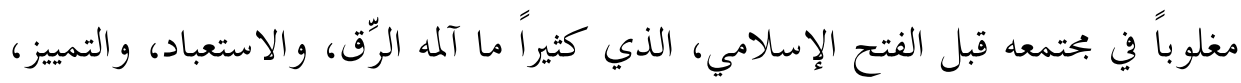

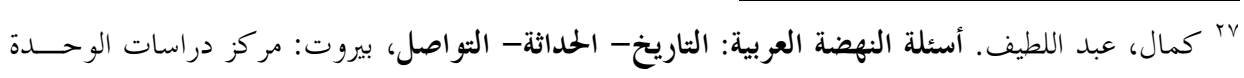

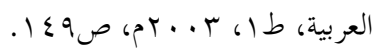

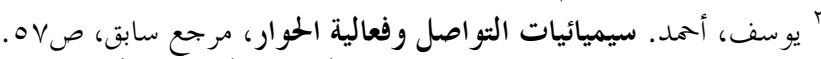

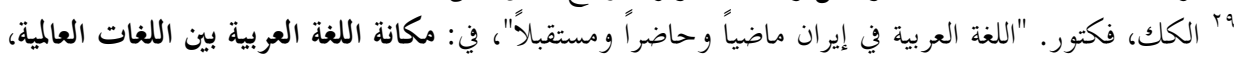

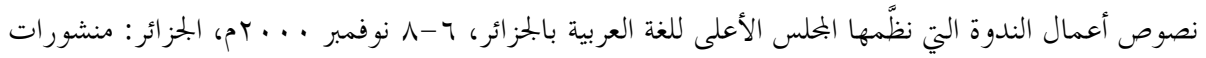

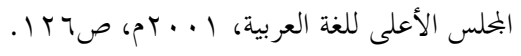


و التهميش، و كل ما تعلَّق باستبعاد فضائل الحرية؛ وللمثال، ومثال ذلـــك الثقافتـــان

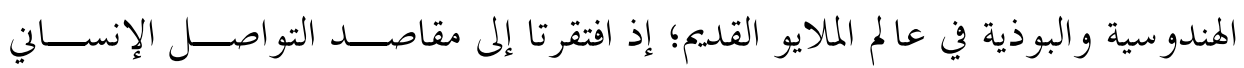

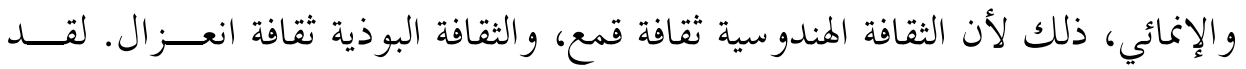

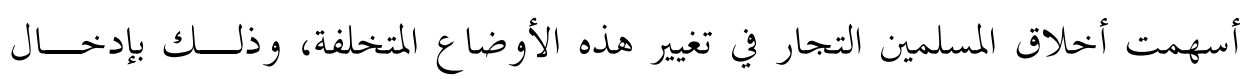

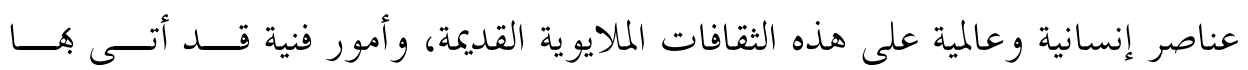

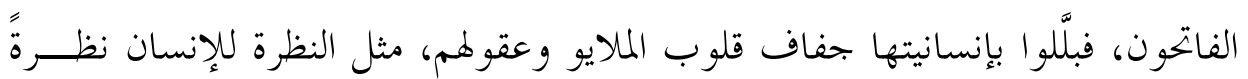

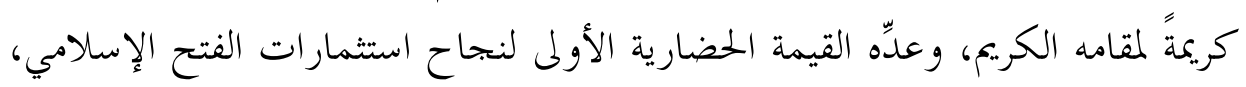

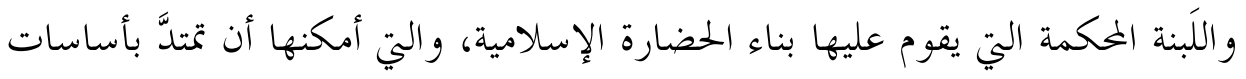

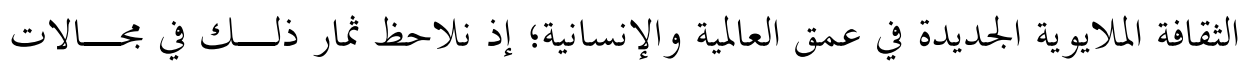

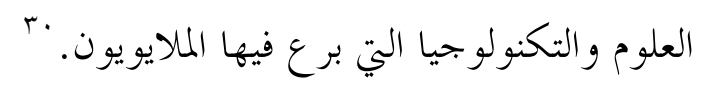

إن الفارق الجوهري بين الفتح والاستعمار، هو أن الفاتحين يتواصلون مع الآخر،

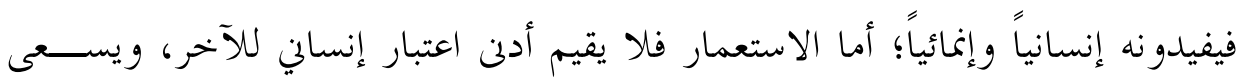

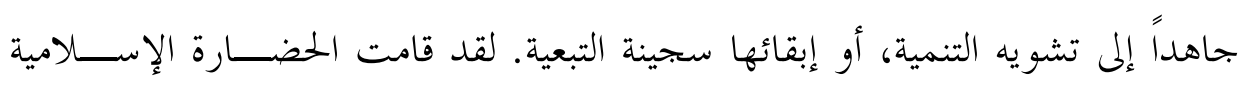

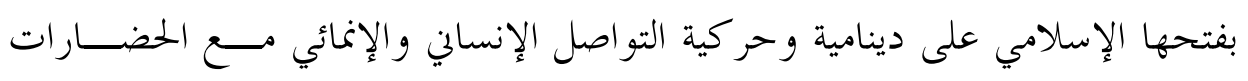

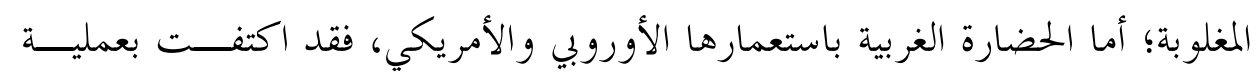

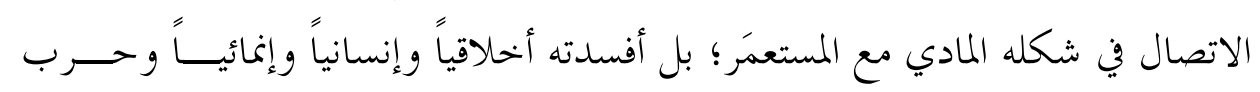

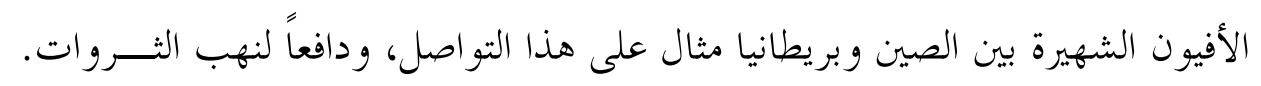

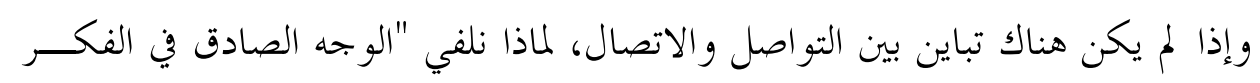

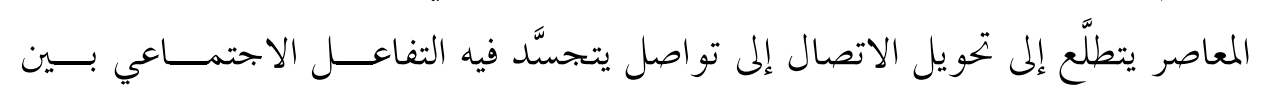

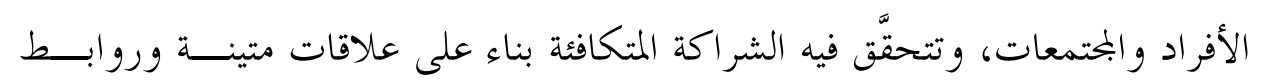

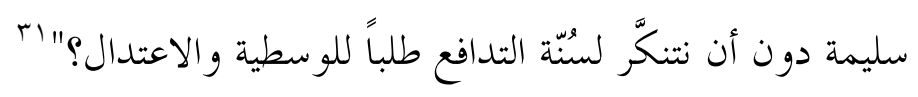
•r انظر: محمد، محاضير. الإسلام والأمة الإسلامية: خطب و كلمات مختارة، بيروت: دار الفكر المعاصــ، ط1ا، 年

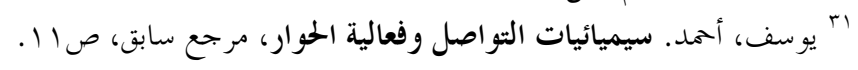




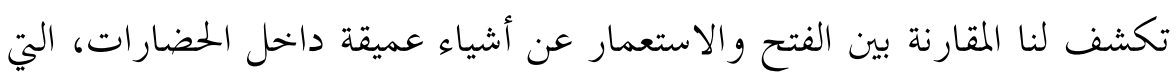

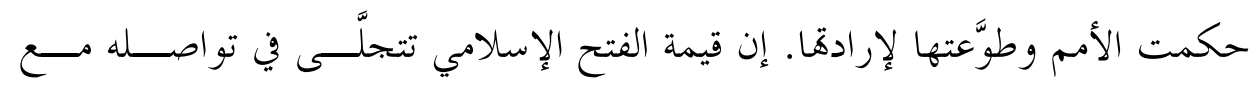

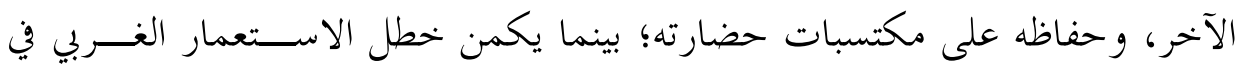

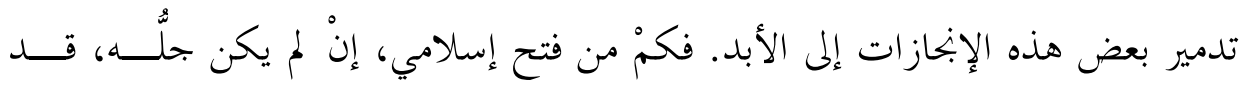

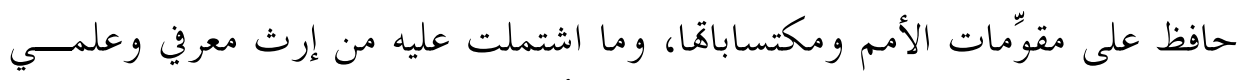

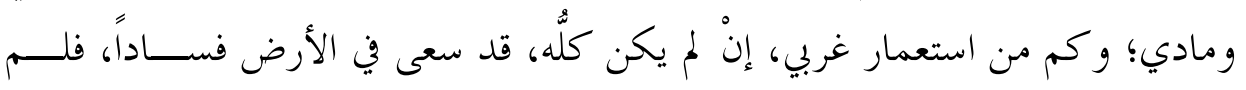

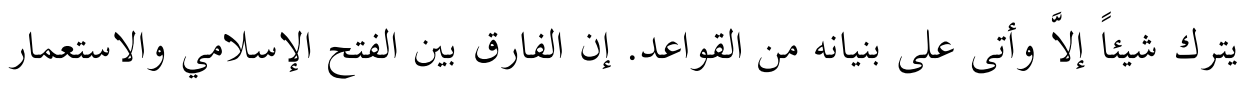

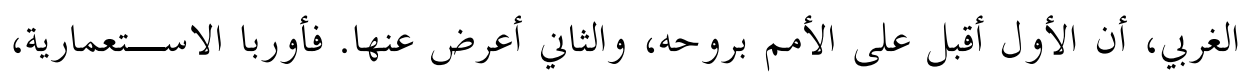

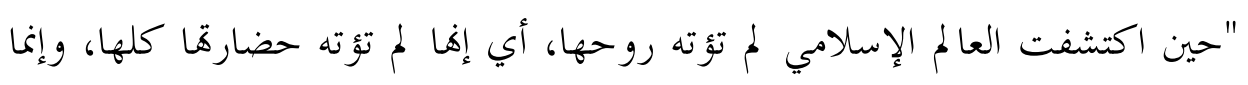

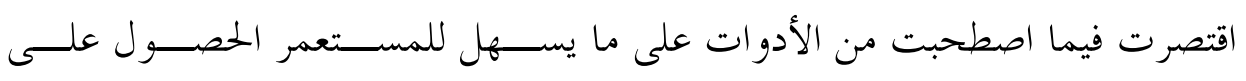

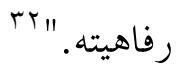

قد لا تبرز قيمة الحضارة الإسلامية في إسلاميتها وتساعحها فحسب، وهذا شــأن

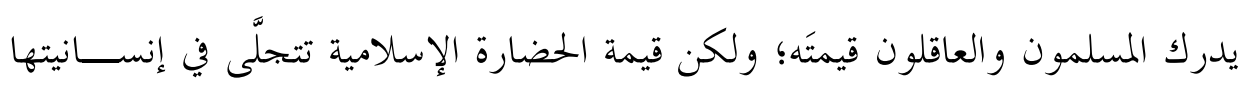

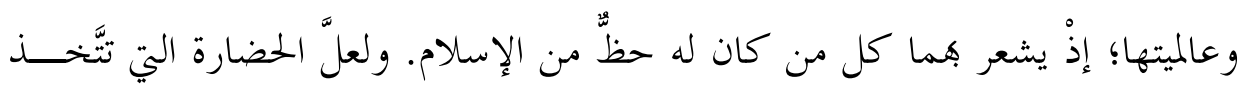

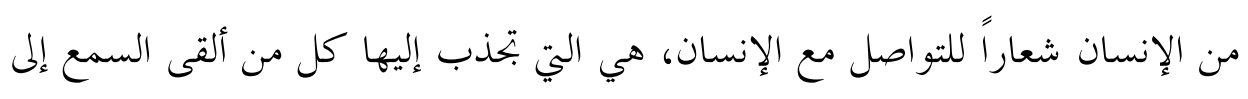

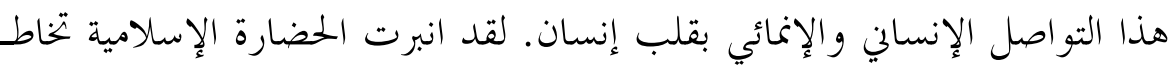

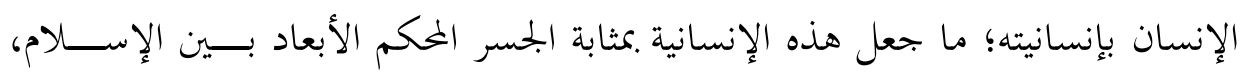

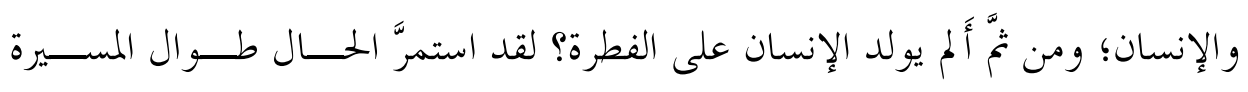

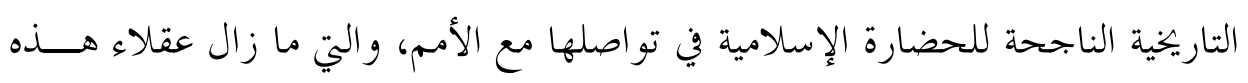

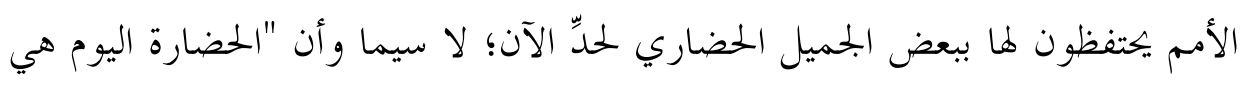

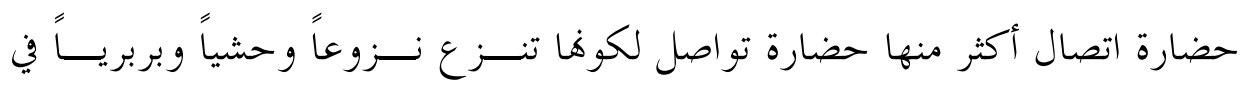
بعض الأحيان إلى التمركز حول الذات بما يتيحه لها التطور التقني الكبير، ولهذا انكبَّت

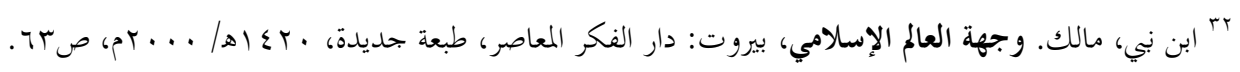


فلسفة ديريدا على نقد هذا النــزوع اللإنساني الذي يلغي الآخر أو يحقره أو يستعبده.

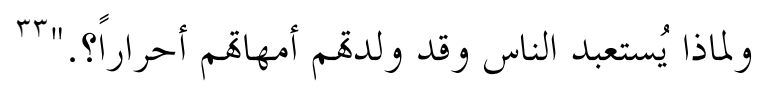

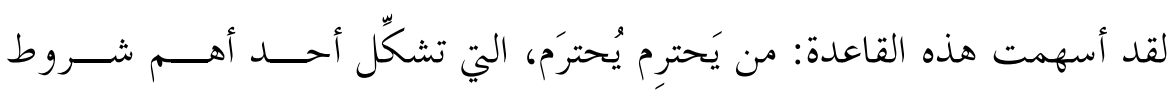

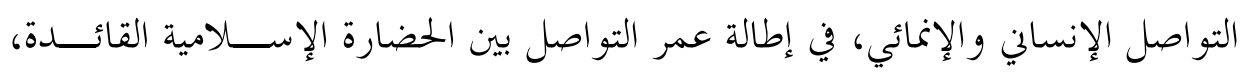

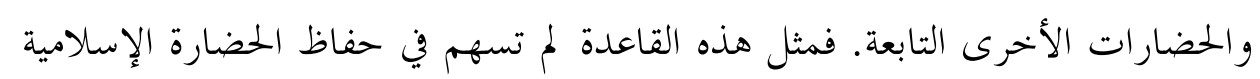

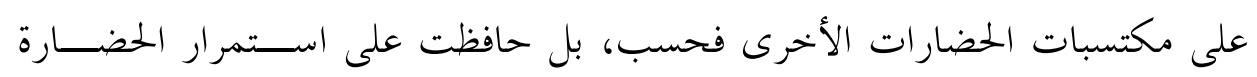

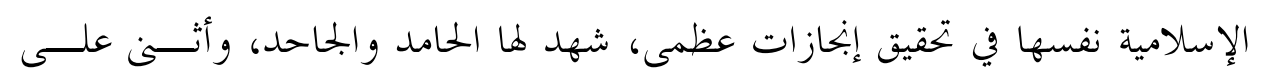

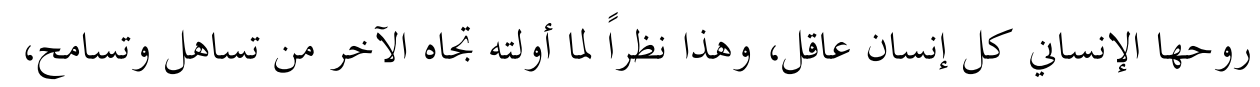

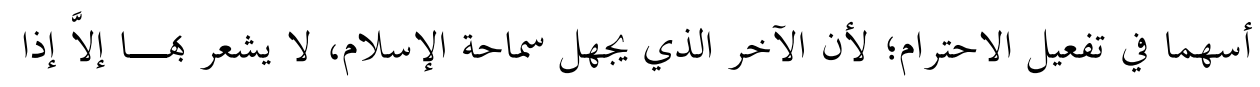

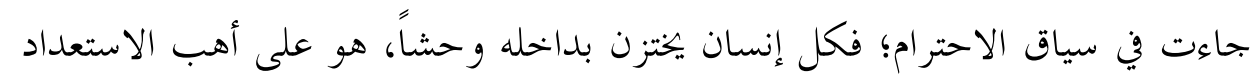

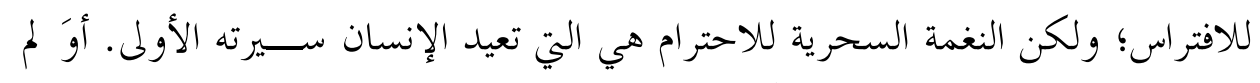

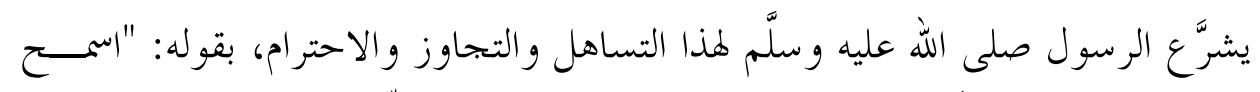

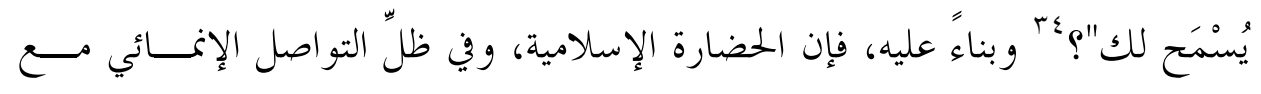

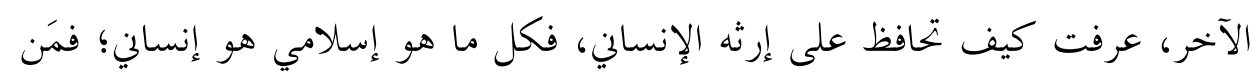
يَحترِم الإسلام، يُحترَم بوصفه إنساناً.

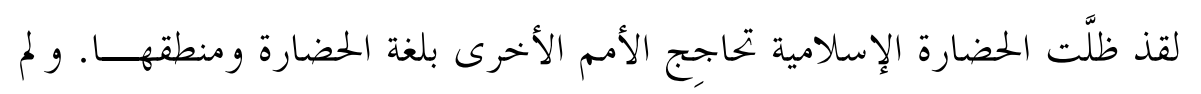

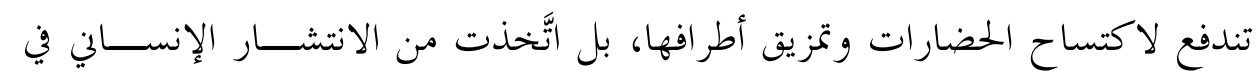

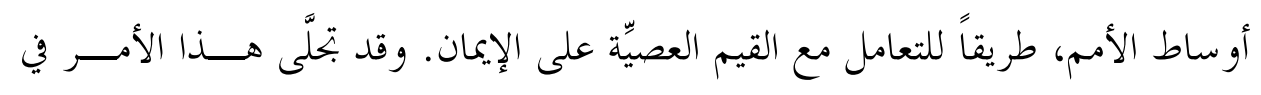

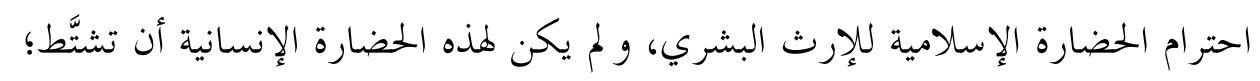

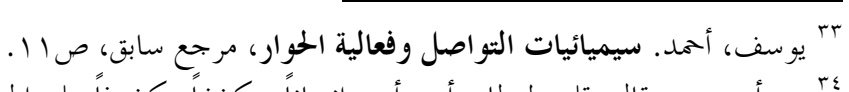

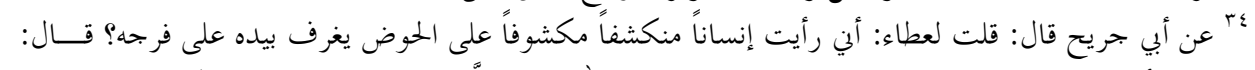

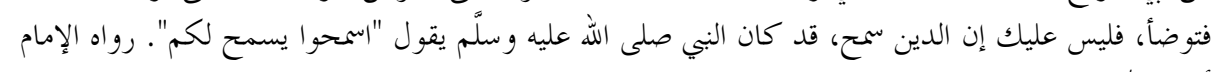

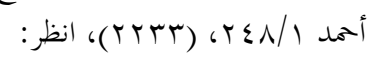
- مسند الإمام أهد بن حنبل. تقعيق: شعيب الأرناؤوط وآخسرون، بـيروت: مؤسســة الرسـالة، طا،

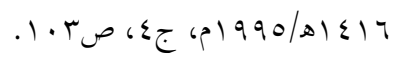


حتى ولو اصطدم ذلك مع ما تنشده هذه الحضارة من روحانيات وأخلاقيات. فمثــل هل

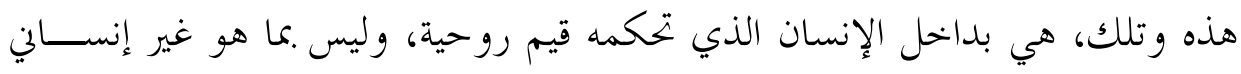

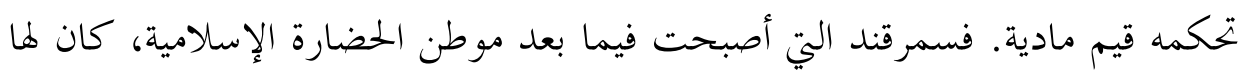

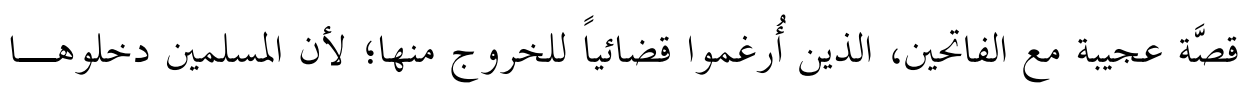

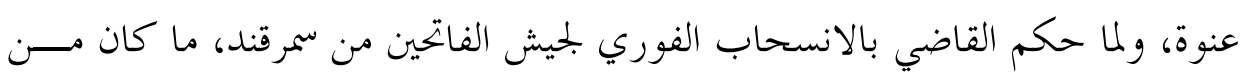

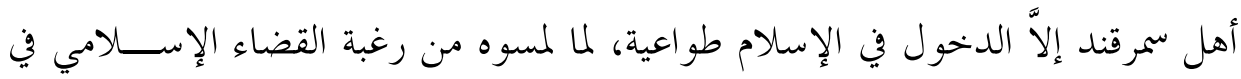

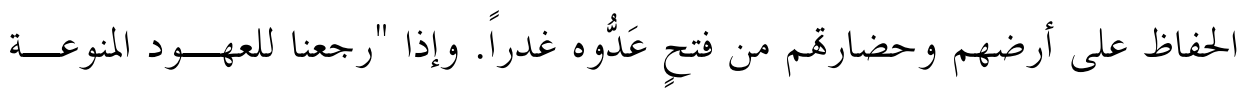

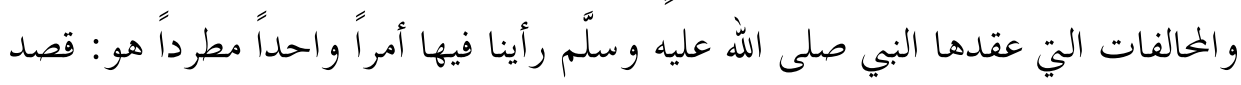

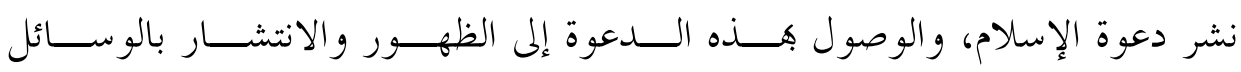

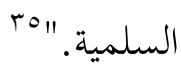

إن الوصول إلى تغيير القيم المادية وإعادة النظر في شرعيتها من الوجود، يكــون

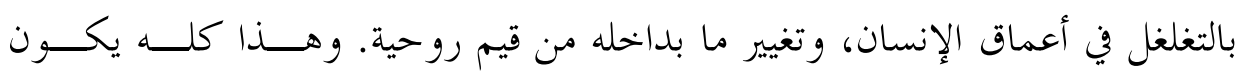

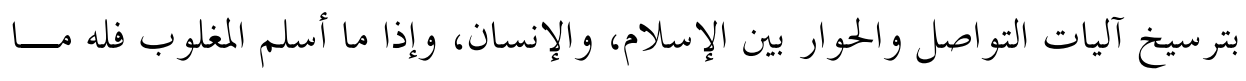

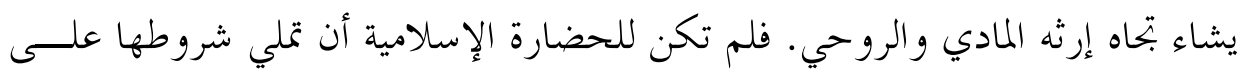

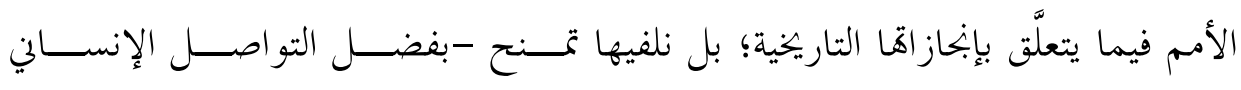

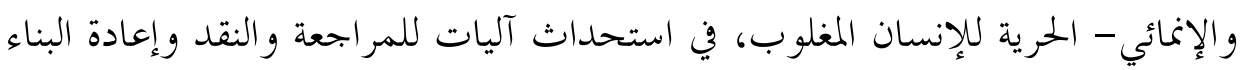

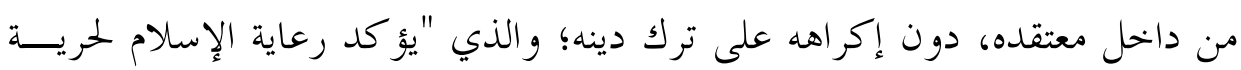

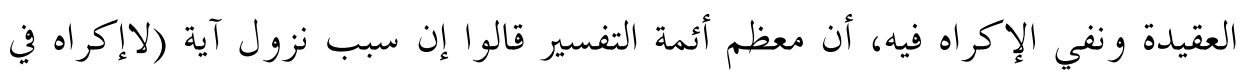

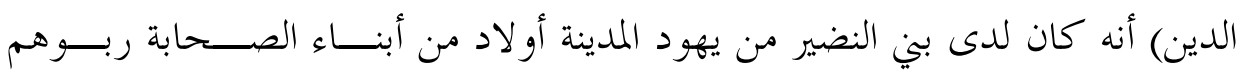

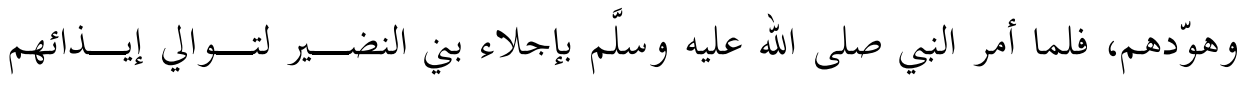

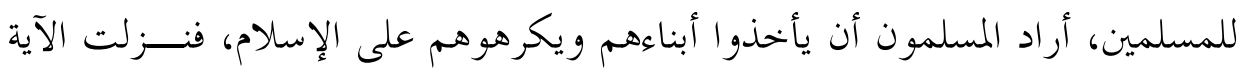

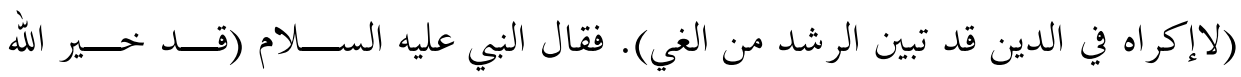

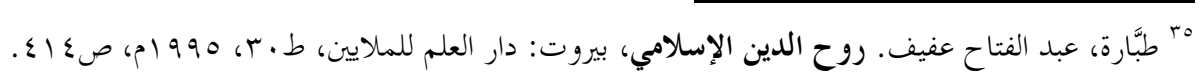




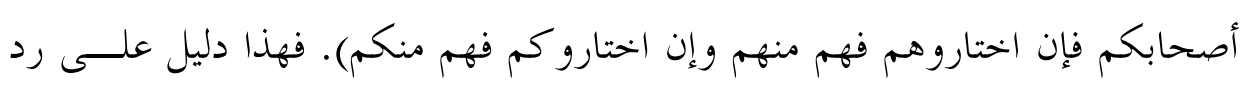

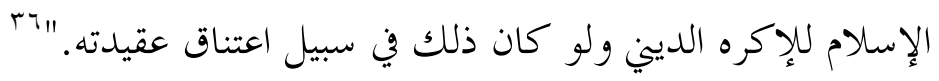

لم يقتصر الأمر في المناقشات الدينية وتفعيل الحوار على غير المسلمين؛ بل تعــــاه

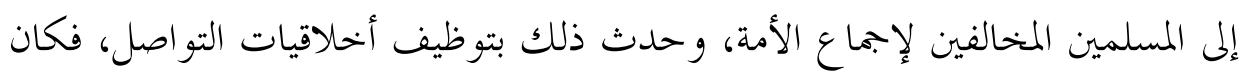

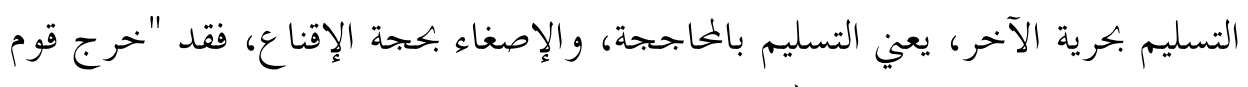

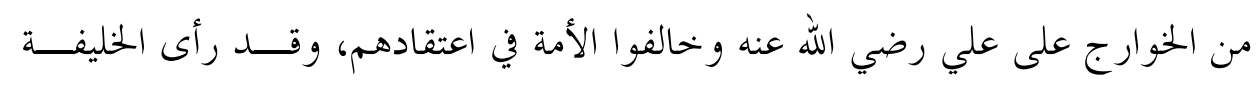

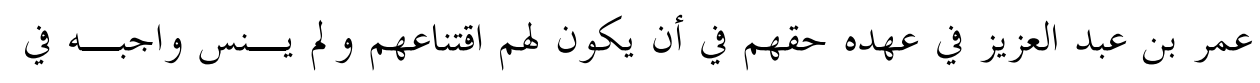

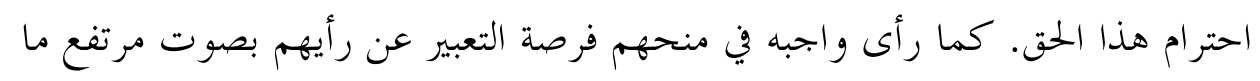

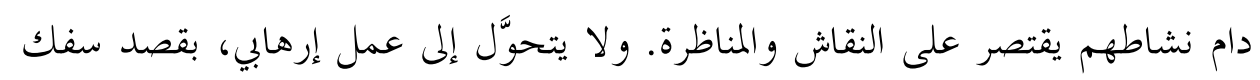

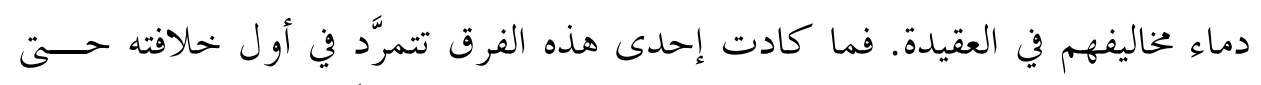

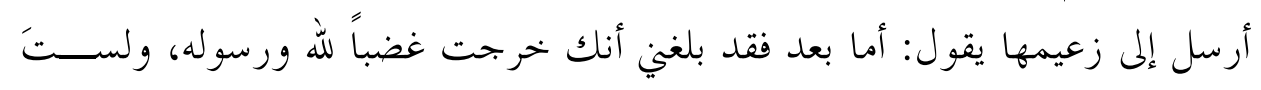

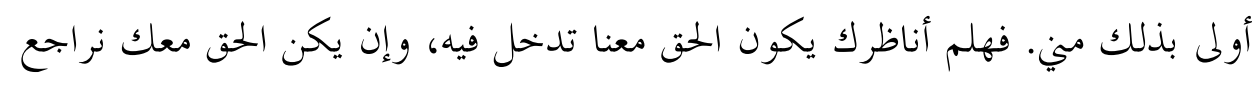

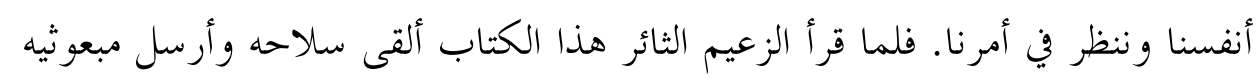

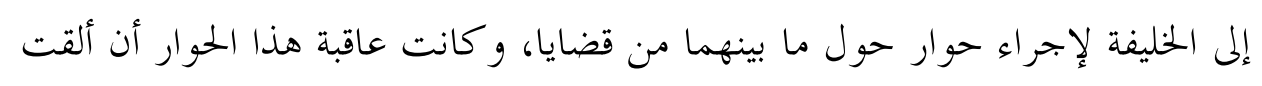

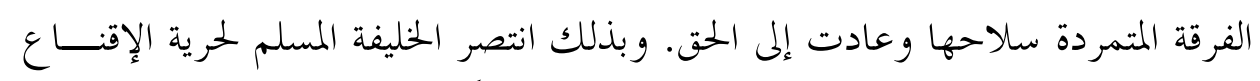

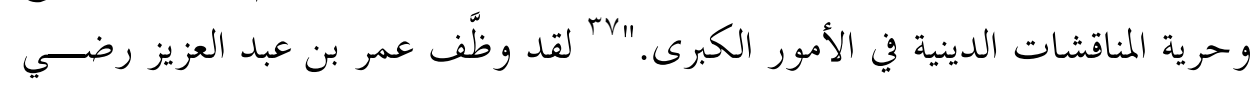

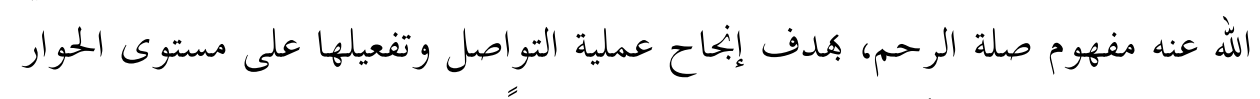

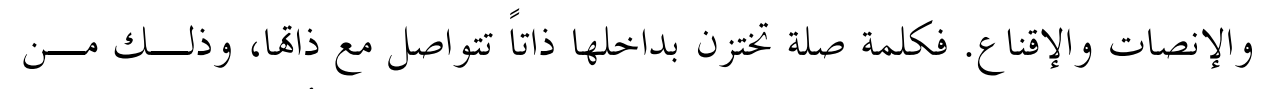

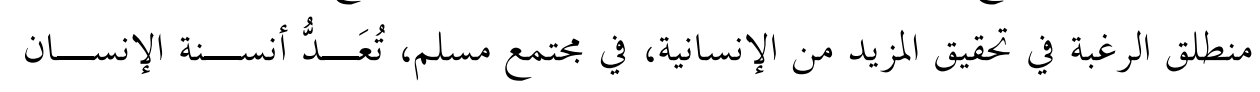

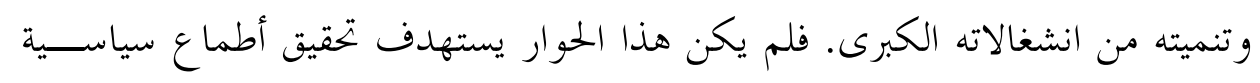

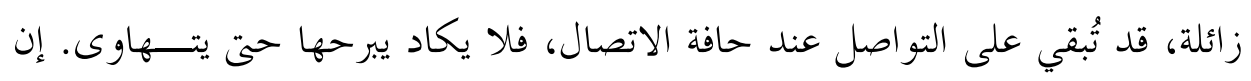

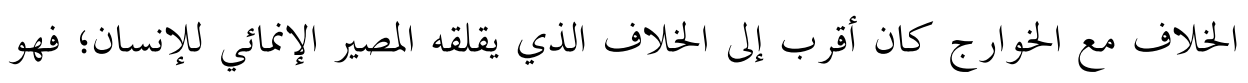

ب" العيلي، عبد الحكيم حسن. الحريات العامة في الفكر والنظام السياسي في الإسلام: دراسة مقارنة، القـاهرة:

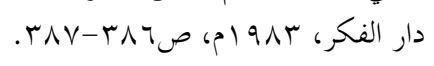

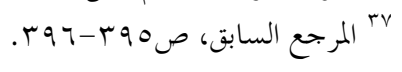




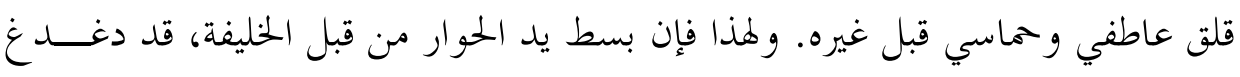

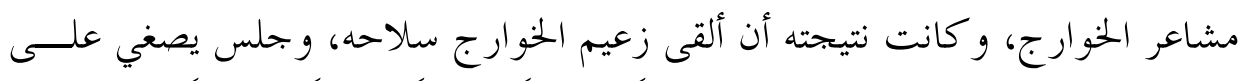

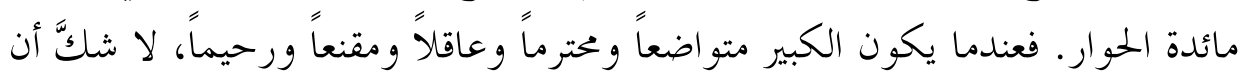

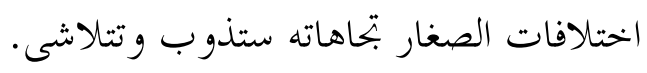
لقد أدركت الحضارة الإسلامية أن الحضارات السامية هي التي تغترف من معسين

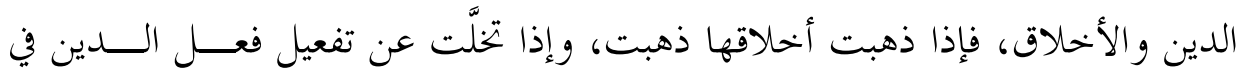

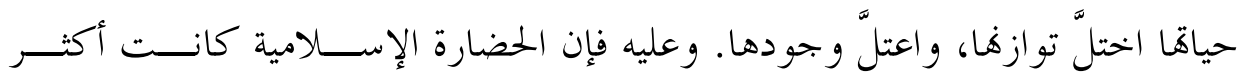

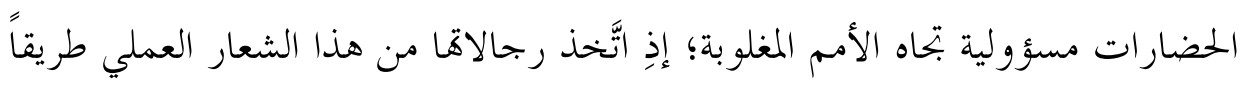

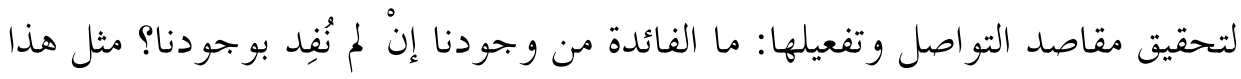

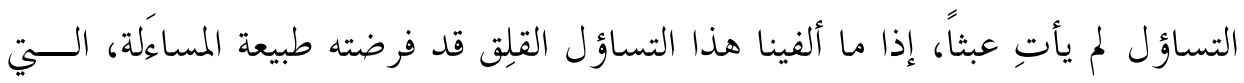

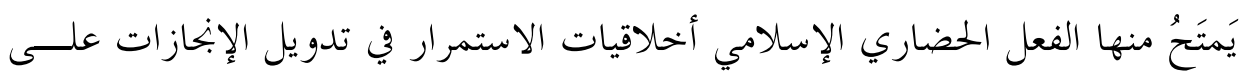

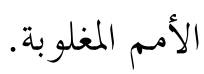

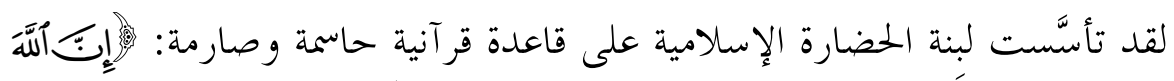

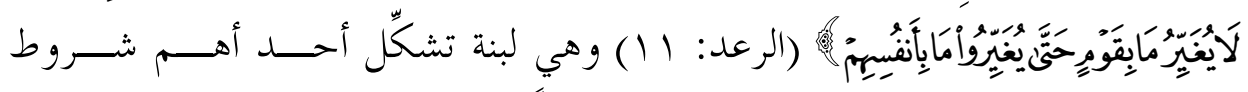

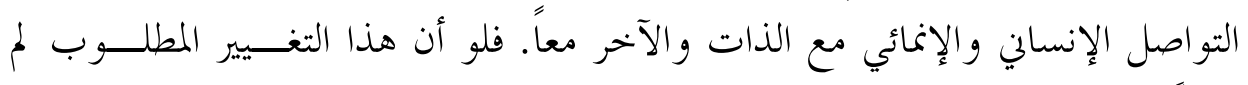

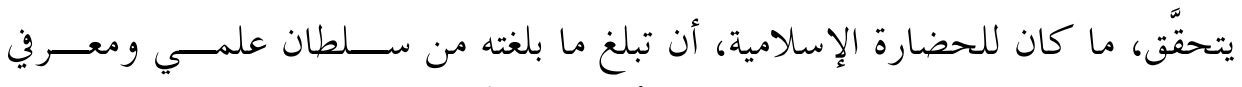

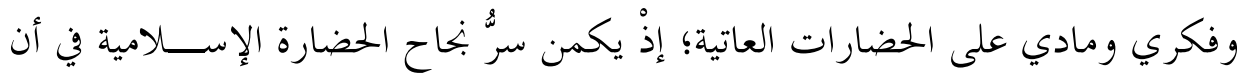

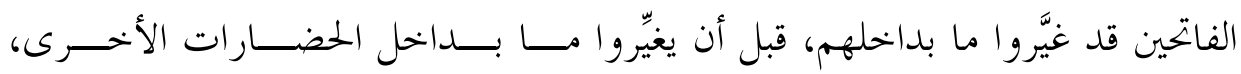

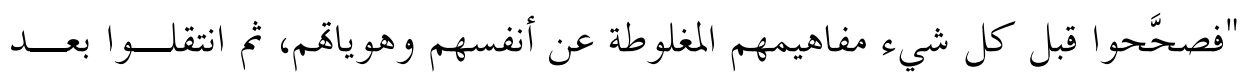

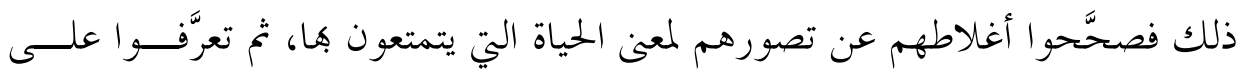

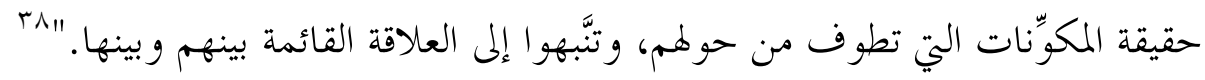

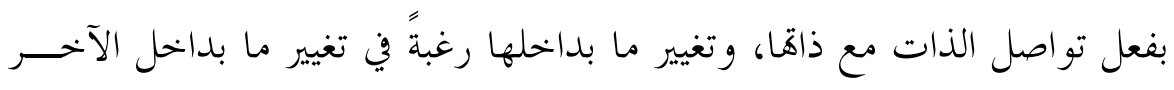

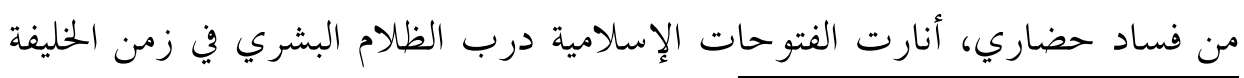

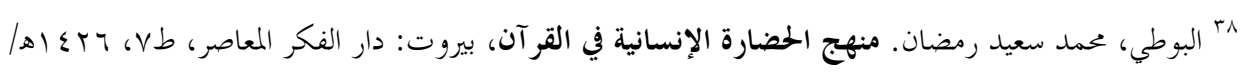




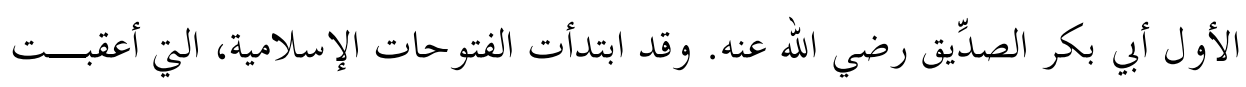

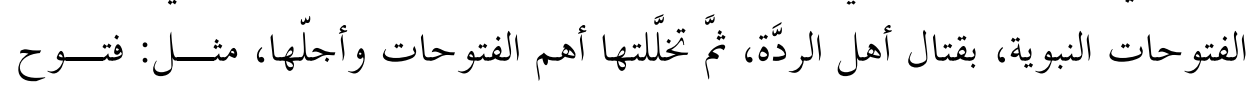

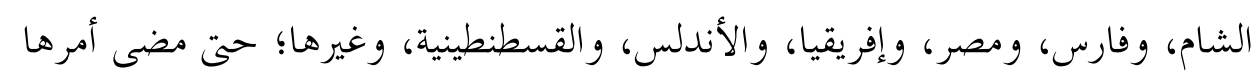

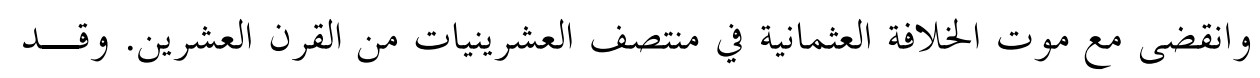

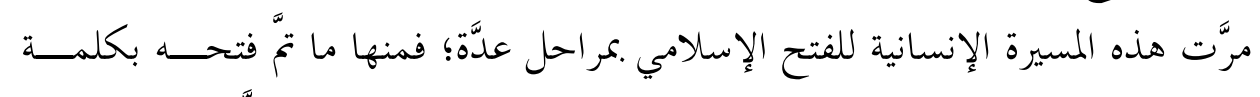

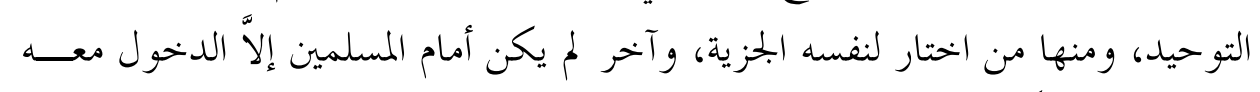

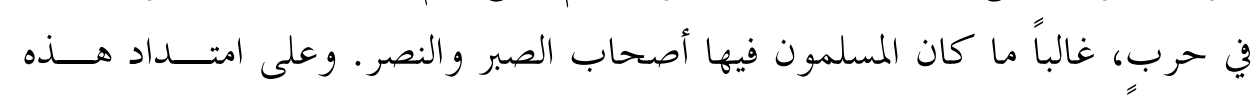

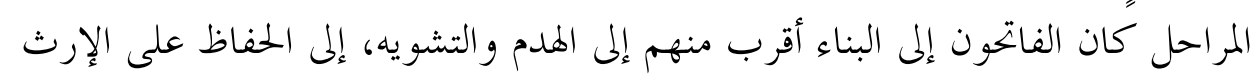
الحضاري للمغلو بين أقرب منه إلى التخريب والفي الإفساد.

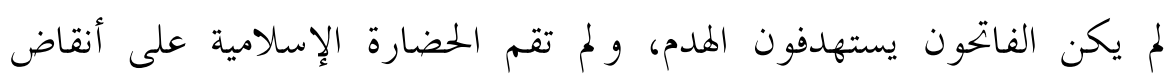

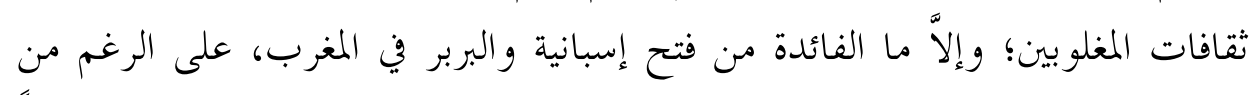

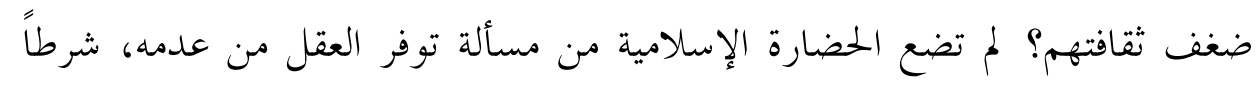

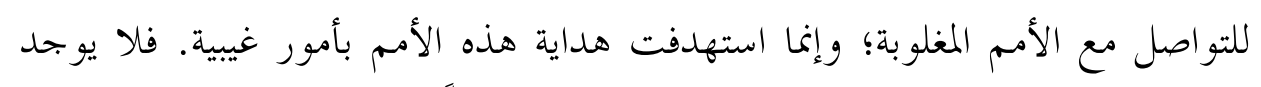

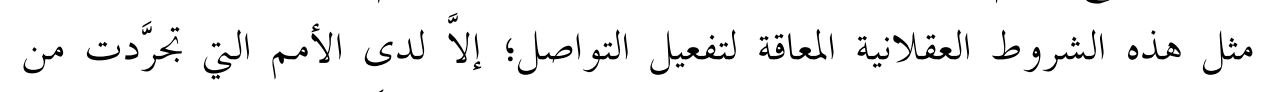

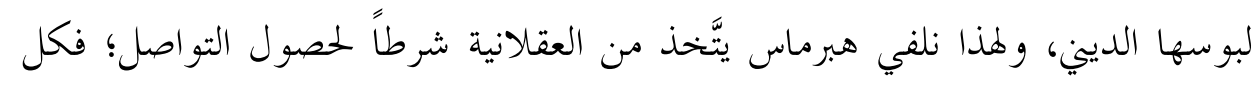

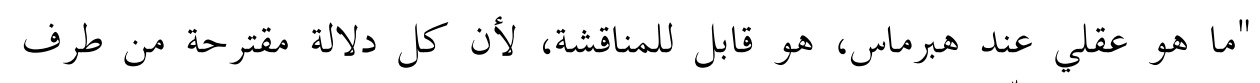

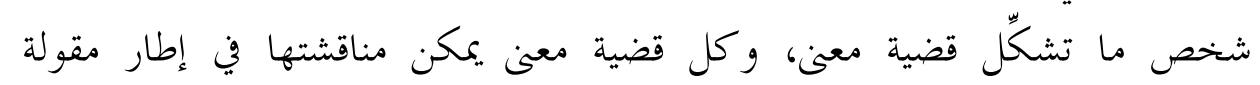

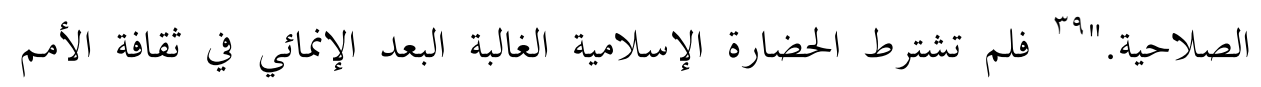

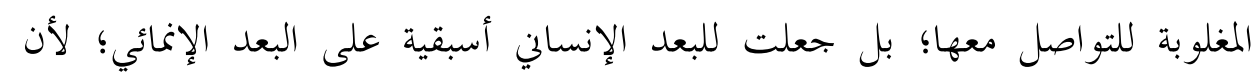

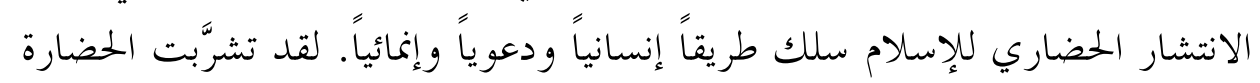

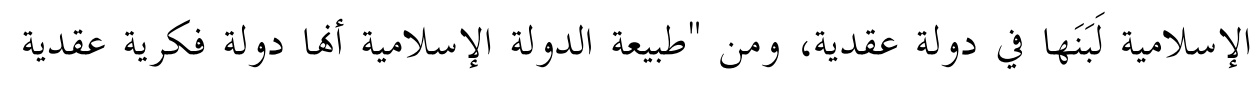

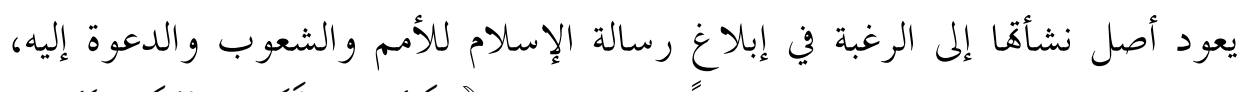

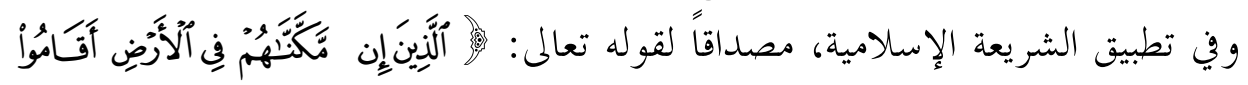

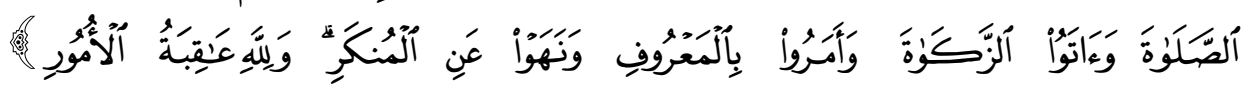

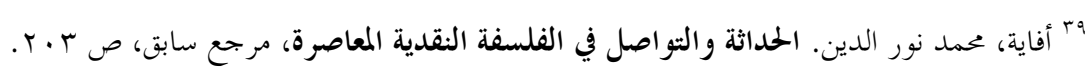




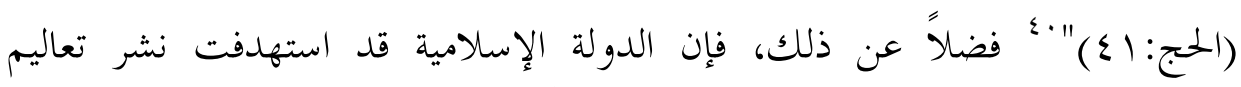

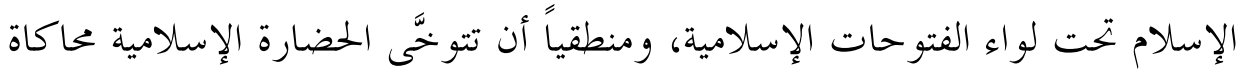

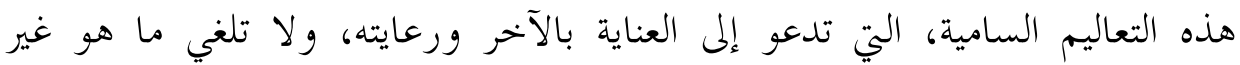
عقلاني من دائرة الحوار و التواصل.

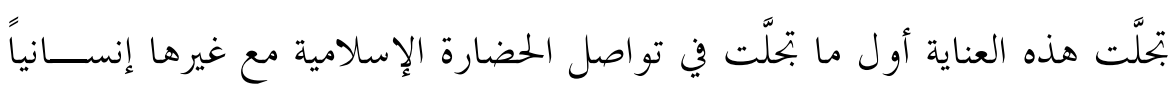

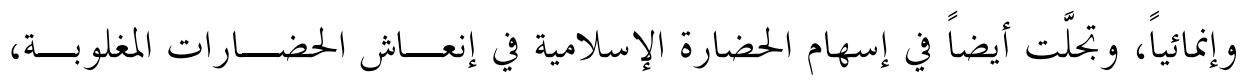

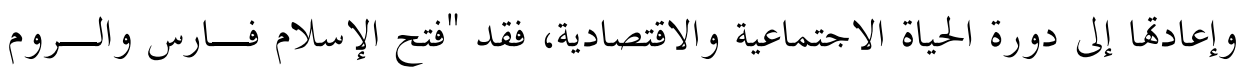

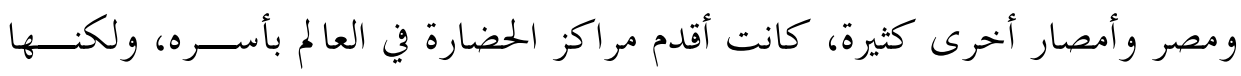

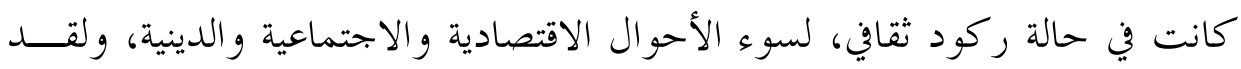

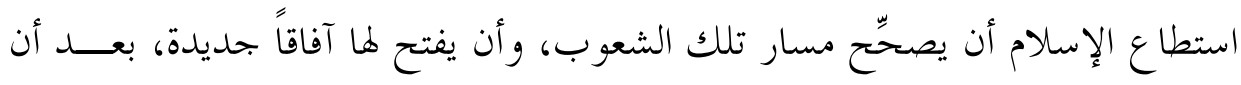

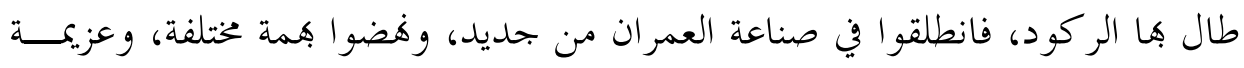

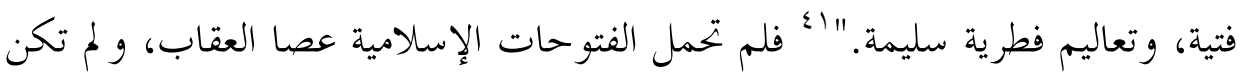

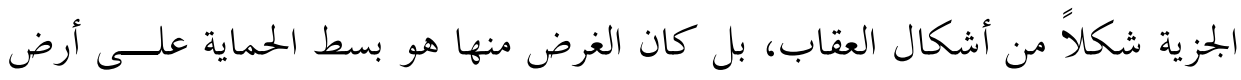

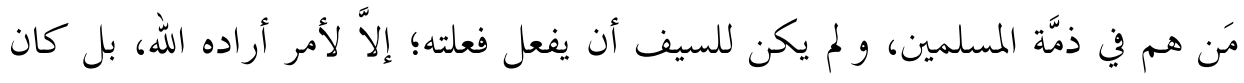

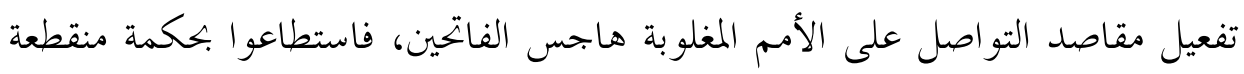

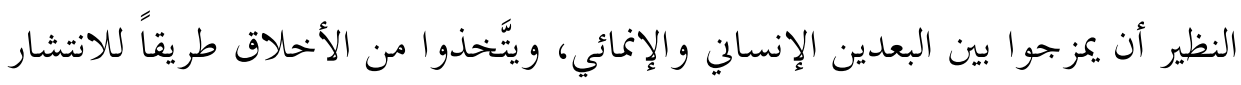

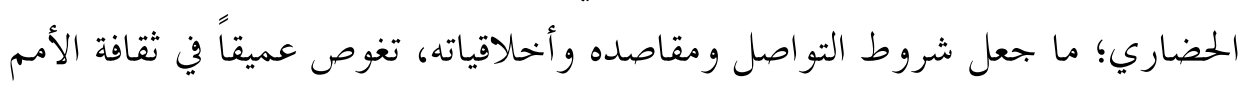
التي كانت مغلوبة وقتذاك. - ماك.

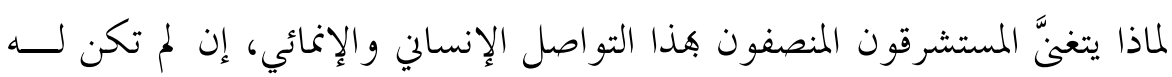

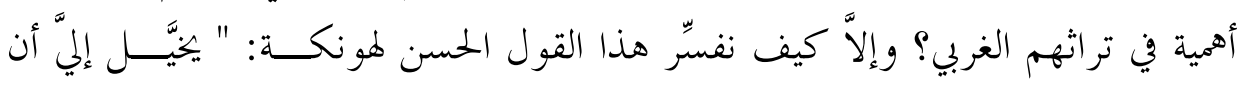

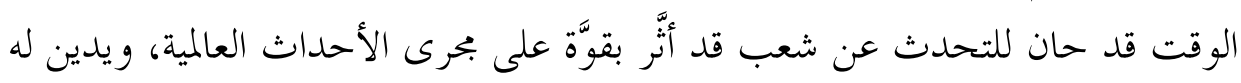

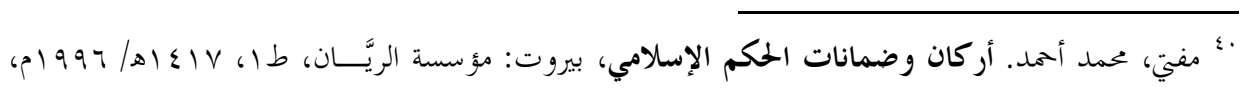

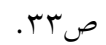

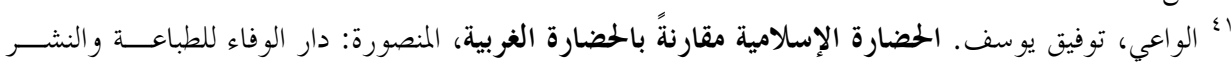

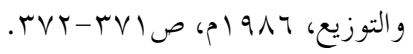




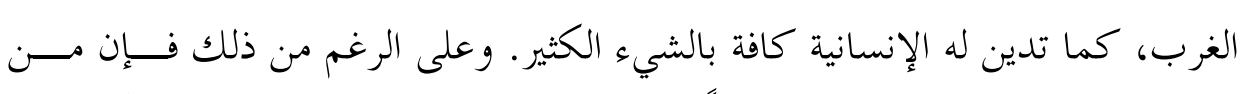

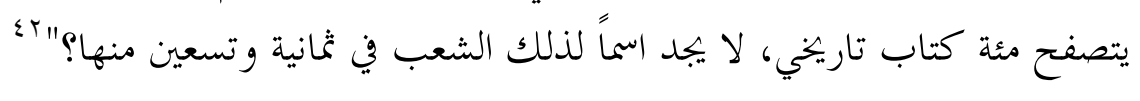

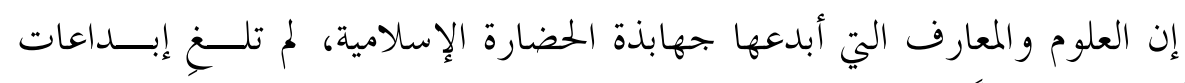

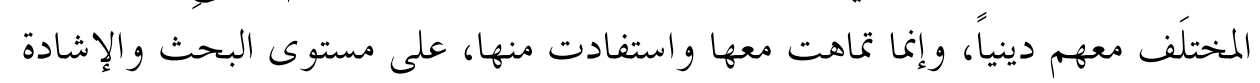

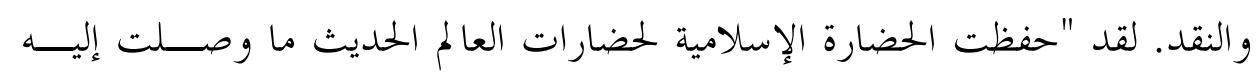

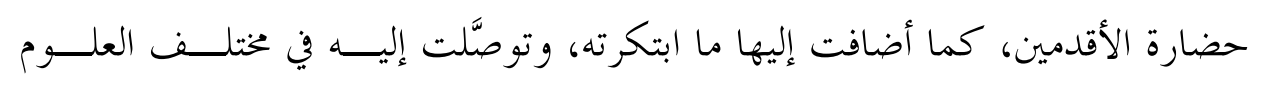

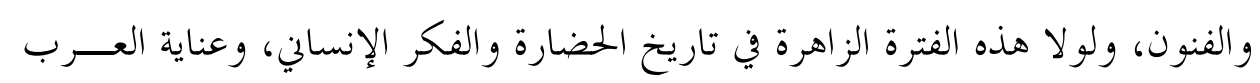

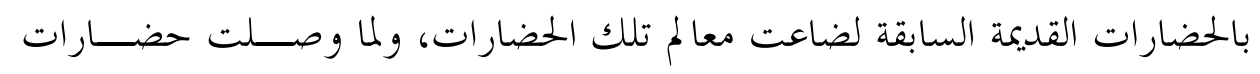

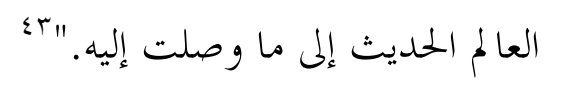

خاتمة

لقد استعرضنا في هذا البحث أخحلاقيات التواصل الإنساني والإنمـــئي، و بســـــان

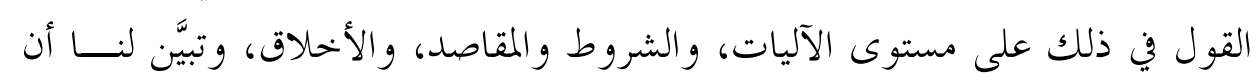

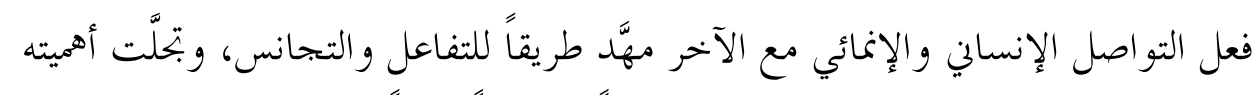

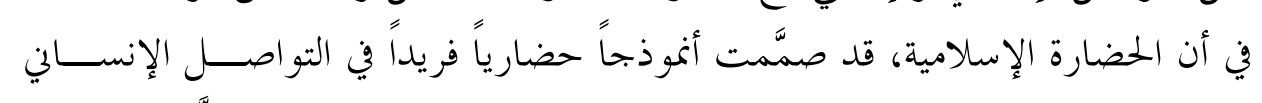

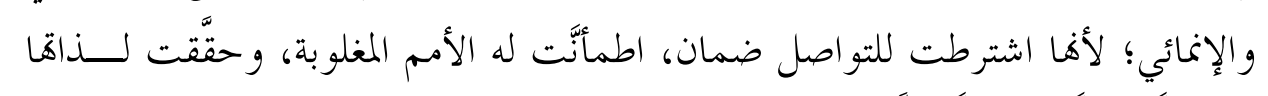

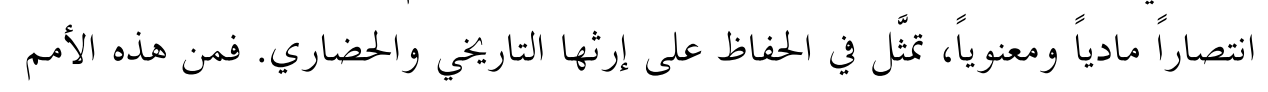

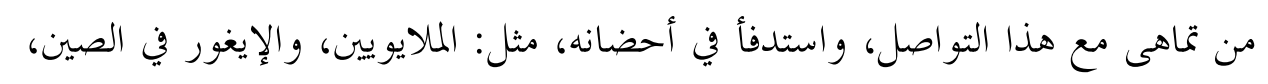

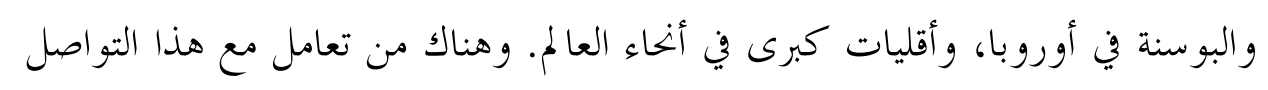

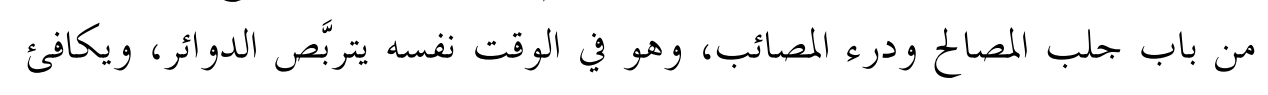

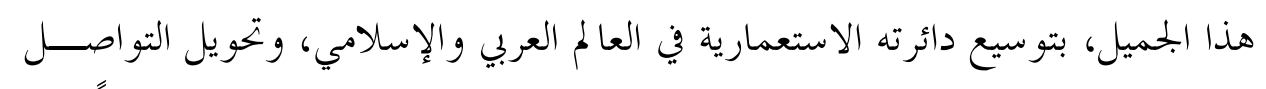

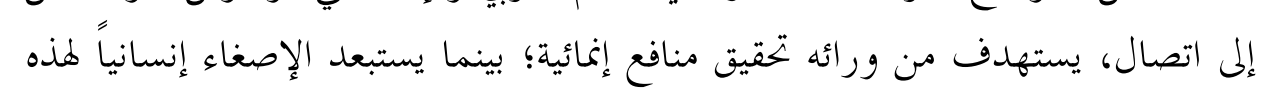

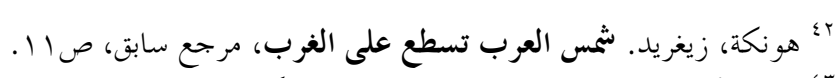

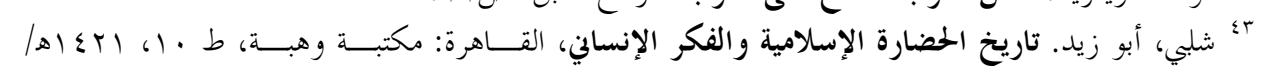

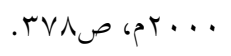




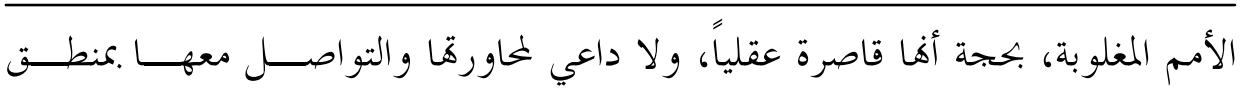

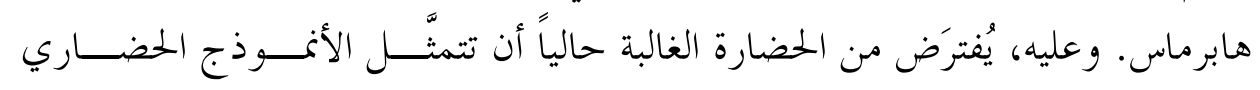

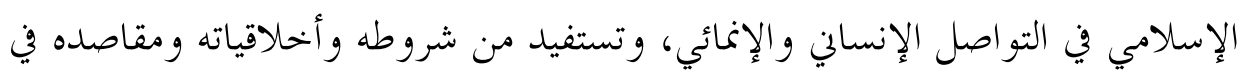

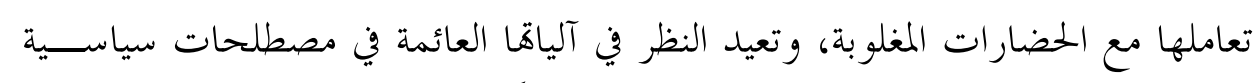

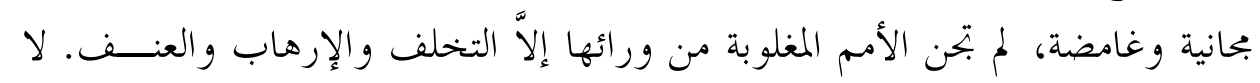

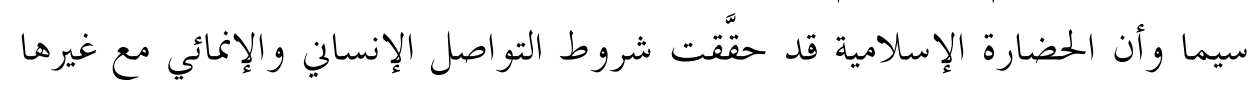

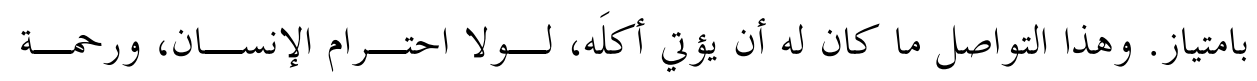

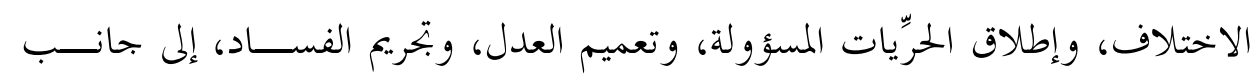

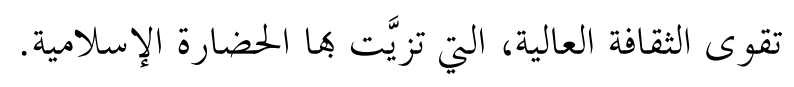

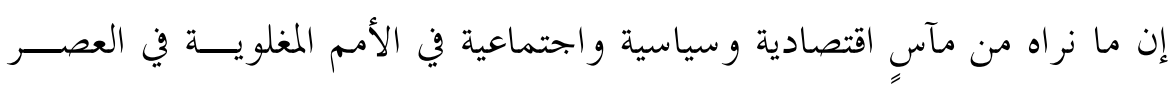

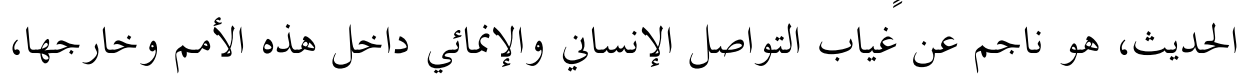

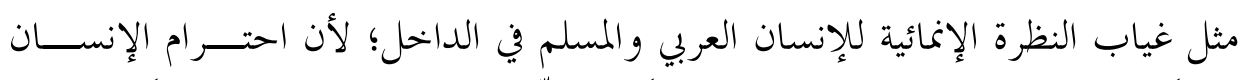

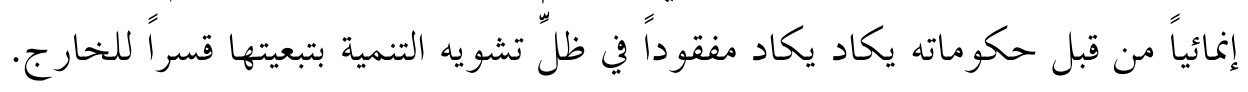

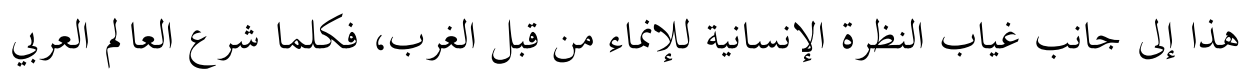

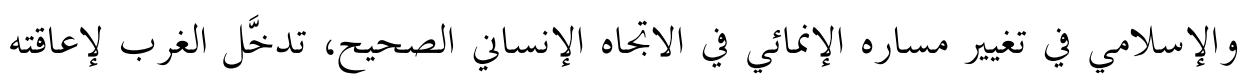

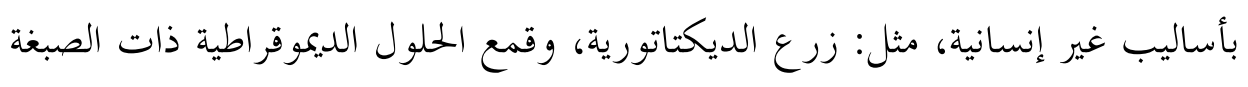

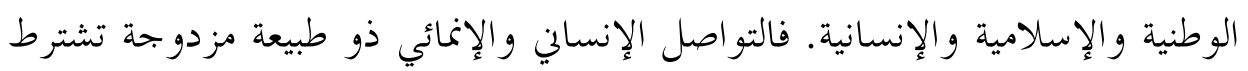

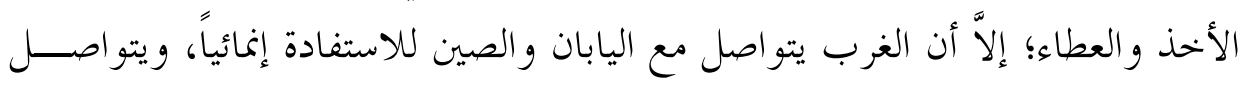

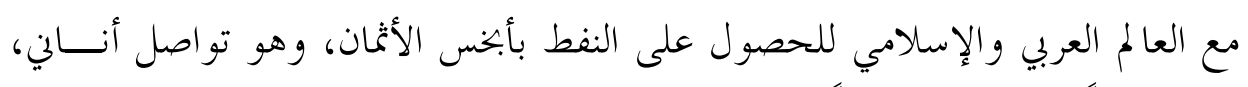
يأخذ إنمائياً ولا يعطي إنسانياً.

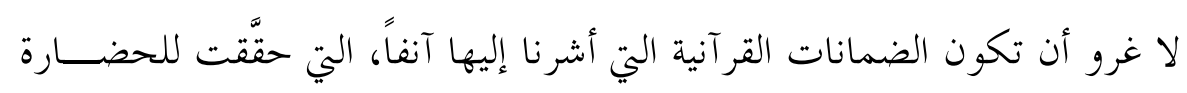

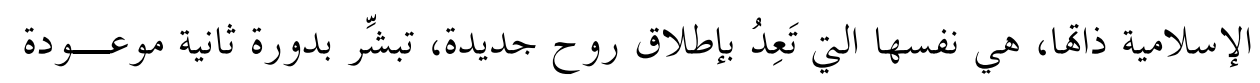

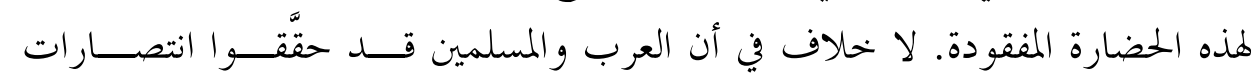

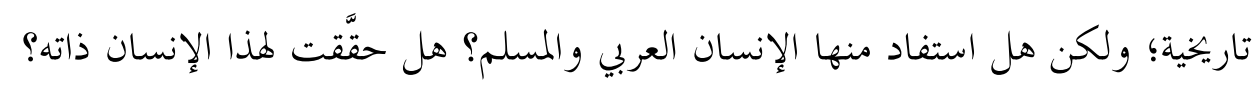




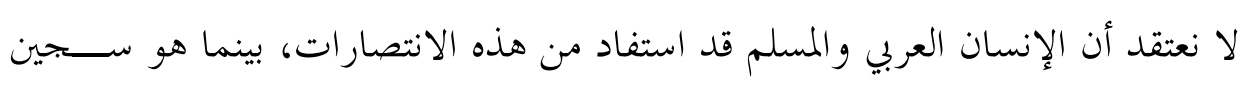

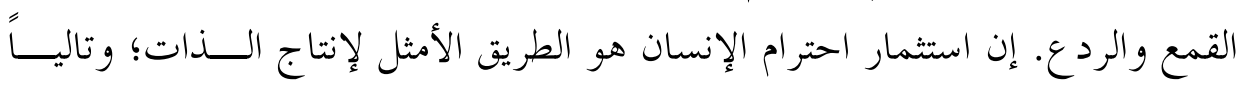

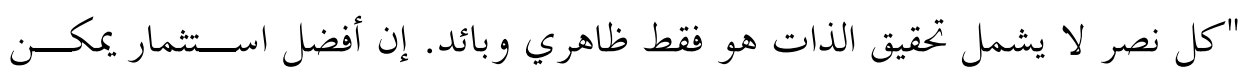

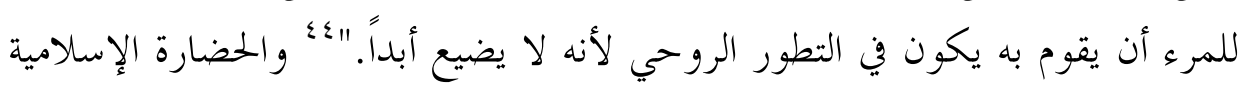

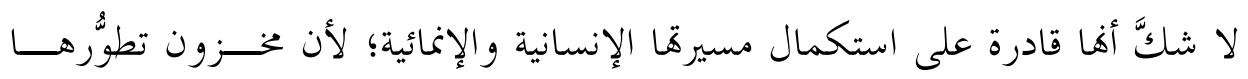

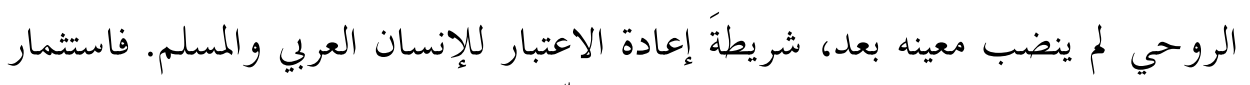

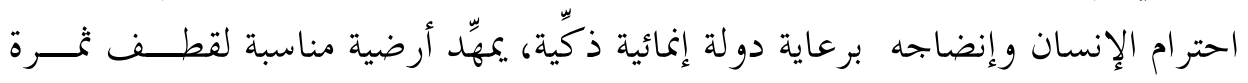

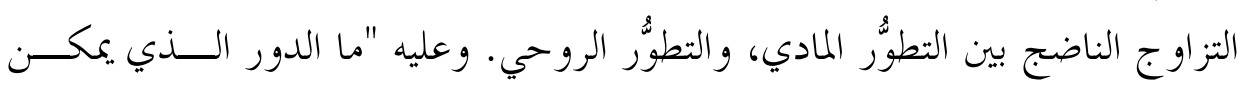

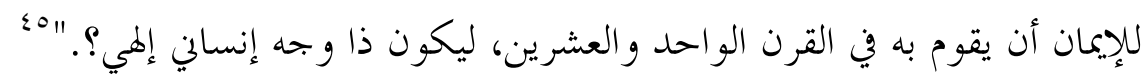
لقد استثمرت الحضارة الإسلامية إبحازات الحضارات المغلوبــة، فاســتمرَّت في عطائها؛ ولو لم تحافظ -وهدَّمت- ما كان أن يكون لها هذا الصدى التاريخي الكــــير؛

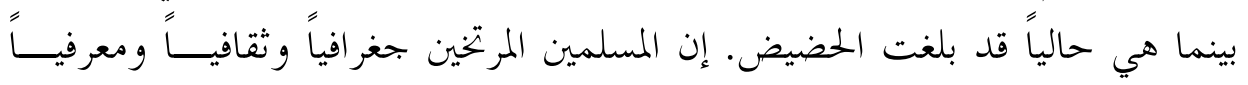
وعلمياً، هـم أصلاب في التاريخ بأخلاقهم و سماحتهم و وحسن فعل تو اصلهم الإنســاني

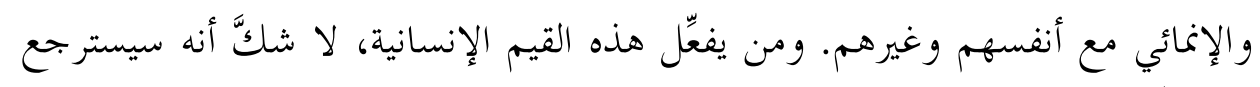

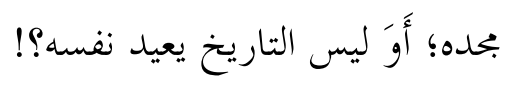

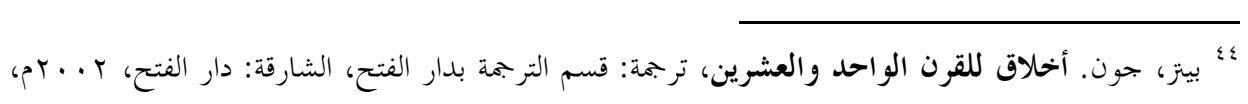

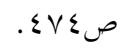
•؛ جارودي، روجيه. كيف نصنع المستقبل؟، ترجمة وتقديع: منى طلبة وأنور مغيث، القاهرة: دار الشروق، طا، 